\begin{abstract}
Title of Document:

REAL-TIME MONITORING AND

FORECASTING OF ODOR AFTER

DEWATERING IN WASTEWATER

TREATMENT

Ampun Janpengpen, Master of Science, 2006

Directed By:

Professor Gregory B. Baecher

Department of Civil and Environmental

Engineering
\end{abstract}

District of Columbia Water and Sewer Authority (DCWASA) operates an advanced wastewater treatment plant that treats approximately $370 \mathrm{mgd}$ of wastewater and generates over 400,000 wet tons of biosolids each year. The reduction of biosolids odors at the plant before distribution to the field sites is therefore, a high priority. Each unit process of a wastewater treatment plant has the potential to generate odor-causing compounds. Total Reduced Sulfur is one of the main components of the odor-generated by wastewater treatment facilities and is the dewatered solids emissions monitored by this study.

Many studies have indicated that odors are generated from the upstream processes and from storage, but this research presents information about the odors arising after dewatering. It demonstrates a statistical model that forecasts which factors are significant contributions to odors and which can be used to forecast biosolids odor. The model indicates that secondary west odd blanket depth is the most 
significant factor for odor level after dewatering and at the depth more than $1.8 \mathrm{ft}$ will be caused more odors. In addition, this research provides basic information to compare odor after lime addition which is the next phase of research, and this model can assist DCWASA to schedule routes for distribution of biosolids to field sites. 


\title{
REAL-TIME MONITORING AND FORECASTING OF ODOR AFTER DEWATERING IN WASTEWATER TREATMENT
}

\author{
By \\ Ampun Janpengpen \\ Thesis submitted to the Faculty of the Graduate School of the \\ University of Maryland, College Park, in partial fulfillment \\ of the requirements for the degree of \\ Master of Science \\ 2006
}

Advisory Committee:

Professor Gregory B. Baecher, Chair

Professor Steven A. Gabriel

Professor Eric A. Seagren 
(C) Copyright by

Ampun Janpengpen

2006 


\section{Dedication}

I would like to dedicate this thesis to my parents, my family, my lovely wife, Chonlada Janpengpen, and my new coming son. 


\section{Acknowledgements}

Firstly, I would like to express my sincere gratitude to Professor Gregory B. Baecher, my advisor, for his suggestions and advice thorough the development of this thesis, and for his patience.

I wish to express my sincere thanks to Mark Ramirez, my supervisor at DCWASA, who has directed my work since the first day I became as internship student and for his contribution and criticisms in completing this thesis. I would like to thank Chris Peot, my manager, who gave me the opportunity to work at DCWASA and for his encouragement to complete this thesis. I would also like to thank everyone at the Department of Wastewater Treatment for their support.

I would like to thank Dr. Hyunook Kim for his helpful suggestions and directions.

I would like to thank you Dr. Steven A. Gabriel and Dr. Eric A Seagren for agreeing to be my committee members, and suggestions for this thesis.

Lastly, I would like to thank Royal Thai Army for giving me a great opportunity to study master degree in the US and the financial support during my study. 


\section{Table of Contents}

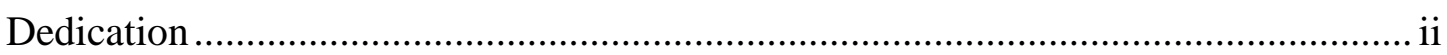

Acknowledgements .................................................................................................ii

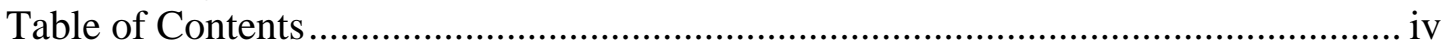

List of Tables ……............................................................................................ vi

List of Figures .............................................................................................. vii

Chapter 1: Introduction .......................................................................................... 1

1.1 Section 1 Overview of District of Columbia Water and Sewer Authority ... 1

1.2 The Scope of the Project.......................................................................... 5

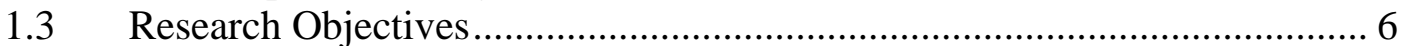

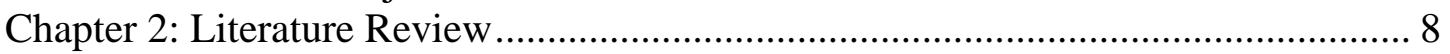

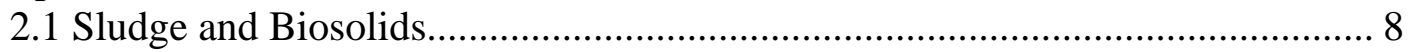

2.2 Odorous Compound and Measurement at Blue Plain......................................... 12

2.3 Process Variables .................................................................................... 15

2.3.1 Ferric Chloride $\left(\mathrm{FeCl}_{3}\right)$ addition ............................................................ 15

2.3.2 Waste Pickle Liquor (WPL) addition ...................................................... 16

2.3.3 Sodium Hypochlorite ( $\mathrm{NaOCl}$ ) Addition...................................................... 16

2.3.4 Polymer Addition..................................................................................... 17

2.3.5 Sludge Blanket Depth .............................................................................. 18

2.3.6 Return Activated Sludge (RAS)................................................................. 19

2.3.7 Blend Ratio by volumetric (TPS/ [TPS+TWAS]) or \% of TPS in Blend

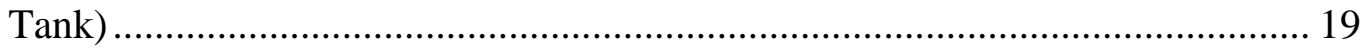

2.3.8 Percent Solid of Gravity Thickening (GT) in Blend................................... 20

Chapter 3: Process Variables Data and Monitoring Data ............................................. 21

3.1 Process Variables Data …………………………..................................... 21

3.1.1 Ferric Chloride Addition...................................................................... 22

3.1.2 Waste Pickle Liquor (WPL) Addition .......................................................... 23

3.1.3 Sodium Hypochlorite Addition................................................................... 23

3.1.4 Polymer Addition.................................................................................... 24

3.1.5 Sludge Blanket Depth ............................................................................. 27

3.1.6 Return Activated Sludge (RAS)................................................................ 29

3.1.7 Blend Ratio (Percent of TPS by volume in Blend Tank)............................. 30

3.1.8 Percent Solids of Gravity Thickening (GT) in Blend ................................. 32

3.2 Real-Time Odor Monitoring ............................................................................. 34

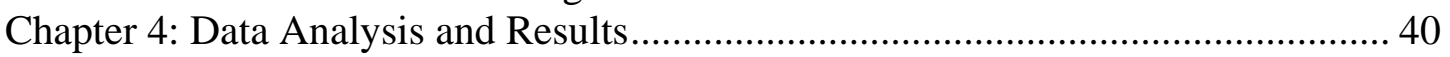

4.1 Graphical analysis and Correlation Analysis .................................................... 40

4.1.1 Graphical Analysis................................................................................. 40

4.1.2 Correlation Analysis using STAT Tool ....................................................... 63

4.1.3 Correlation between process variables and total reduced sulfur from

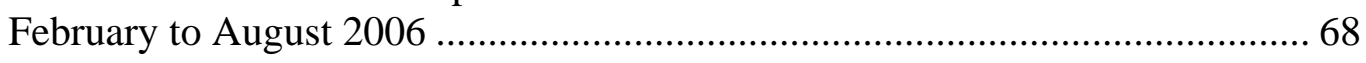

4.1.4 Correlation between process variables and total reduced sulfur from

February to April 2006.......................................................................................... 70 
4.1.5 Correlation between process variables and total reduced sulfur from May to August 2006 ............................................................................................. 74

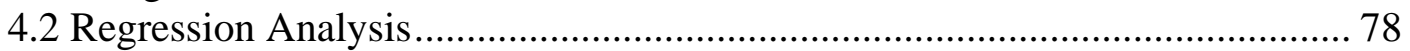

4.2.1 Overview and Criteria.............................................................................. 79

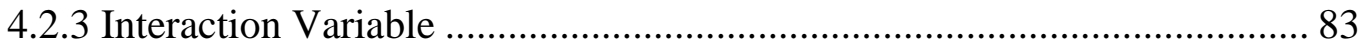

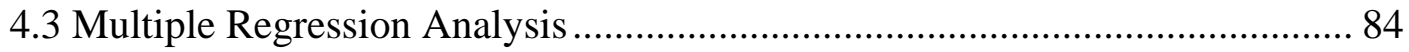

4.3.1 Multiple regression model for the February to August 2006...................... 87

4.3.2 Multiple regression model for February to April 2006................................ 91

4.3.3 Multiple regression model for May to August 2006.................................. 95

4.4 Final Multiple Regression Model .................................................................... 99

Chapter 5: Conclusions and Future Research ......................................................... 102

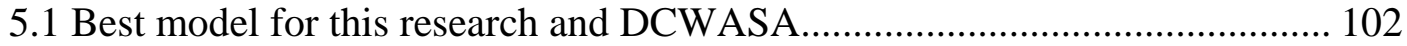

5.2 The Advantage of this Model for DCWASA ………..................................... 104

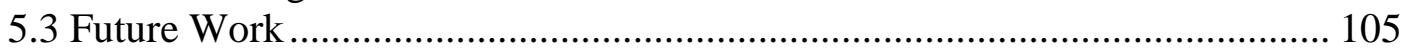

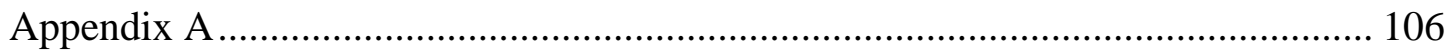

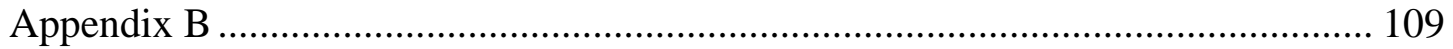

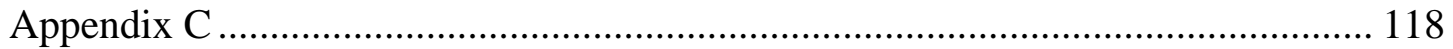

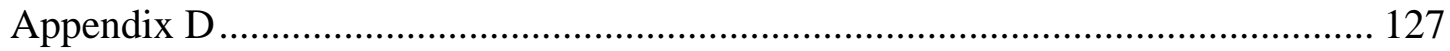

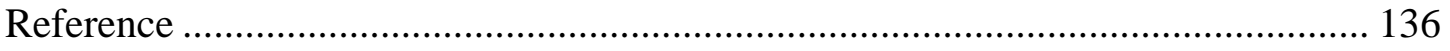




\section{List of Tables}

Table 4-1: The example input data of Process Variables (D-1) and Total Reduce

Sulfur using in STAT Tool for correlation analysis...........................66

Table 4-2: Table 4-2: Correlation between Process Variables (D-1) and Total Reduce

Sulfur from February to August...................................67

Table 4-3: Correlation between Process Variables (D-1) and Total Reduce Sulfur

from February to April..............................................71

Table 4-4: Correlation between Process Variables (D-1) and Total Reduce Sulfur

from May to August...............................................75

Table 4-5: Regression result for February - August period........................89

Table 4-6: Summary of monitored data and forecasted data in Feb - Aug period.....90

Table 4-7: Regression result for February - April period.........................93

Table 4-8: Summary of monitored data and forecasted data in Feb - Apr period......94

Table 4-9: Regression result for May - August period...........................97

Table 4-10: Summary of monitored data and forecasted data in May - Aug

period..............................................................

Table 4-11: Comparison among the best models of each period...................101 


\section{List of Figures}

Figure 1-1: DCWASA Process Diagram (DCWASA, 2005) $\ldots \ldots \ldots \ldots \ldots \ldots \ldots \ldots . \ldots . \ldots . \ldots$

Figure 3-1: Ferric Chloride Addition..........................................22

Figure 3-2: Waste Pickle Liquor (WPL) Addition............................23

Figure 3-3: Sodium Hypochlorite Addition.................................24

Figure 3-4: Polymer Addition at Primary Process...............................25

Figure 3-5: Polymer Addition at Secondary Process.............................25

Figure 3-6: Polymer Addition at Nitrification Process...........................26

Figure 3-7: Polymer Addition at DAF Process.................................26

Figure 3-8: Polymer Addition at Dewatering Process............................27

Figure 3-9: Secondary East Blanket Depth.................................28

Figure 3-10: Secondary West Blanket Depth...............................28

Figure 3-11: Return Activated Sludge from Secondary East.......................29

Figure 3-12: Return Activated Sludge from Secondary West......................29

Figure 3-13: Total Primary Sludge (TPS) ................................ 30

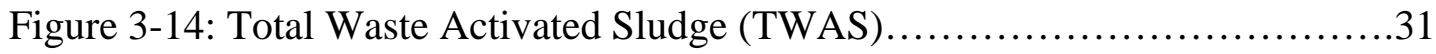

Figure 3-15: Blend Ratio Volumetric (Percent of TPS in Blend Tank)..............31

Figure 3.16: Blend Ration Volumetric (Percent of TWAS in blend tank)...........32

Figure 3-17: Percent solids of Gravity Thickening (GT) in Blend..................33

Figure 3-18: Percent solids of Dissolved Air Flotation (DAF) in Blend..............33

Figure 3-19: Location of Real-Time Monitored Devices........................35

Figure 3-20: Location to Monitor Total Reduce Sulfur...........................36

Figure 3-21: The container of both devices.................................36 
Figure 3-22: OdaLog Low Range and OdaLog (0-50 PPM)......................37

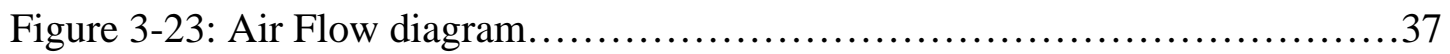

Figure 3-24: Total Reduced Sulfur from OdaLog Low Range (0-2 ppm) ..............38

Figure 3-25: Total Reduced Sulfur Data from OdaLog 0-50 ppm.................39

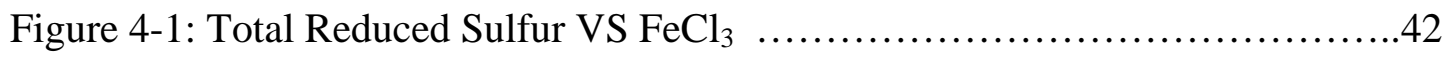

Figure 4-2: Total Reduced Sulfur VS WPL................................43

Figure 4-3: Total Reduced Sulfur VS Summation of $\mathrm{FeCl}_{3}$ and WPL..............44

Figure 4-4: Total Reduced Sulfur VS NaOCl...............................45

Figure 4-5: Total Reduced Sulfur VS Secondary East Blanket Depth...............46

Figure 4-6: Total Reduced Sulfur VS RAS East.............................47

Figure 4-7: Total Reduced Sulfur VS Secondary West Blanket Depth...............48

Figure 4-8: Total Reduced Sulfur VS RAS West.............................49

Figure 4-9: Total Reduced Sulfur VS Summation of Blanket Depth................50

Figure 4-10: Total Reduced Sulfur VS Percent Solid of GT in Blend...............51

Figure 4-11: Total Reduced Sulfur VS Percent Solid of DAF in Blend...............52

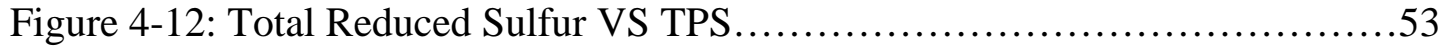

Figure 4-13: Total Reduced Sulfur VS TWAS ..............................54

Figure 4-14: Total Reduced Sulfur VS Summation of TPS and TWAS.............55

Figure 4-15: Total Reduced Sulfur VS Percent of TPS in Blend Tank...............56

Figure 4-16: Total Reduced Sulfur VS Percent of TWAS in Blend Tank.............57

Figure 4-17: Total Reduced Sulfur VS Polymer at Primary ......................58

Figure 4-18: Total Reduced Sulfur VS Polymer at Secondary ....................59

Figure 4-19: Total Reduced Sulfur VS Polymer at Nitrification..................60 
Figure 4-20: Total Reduced Sulfur VS Polymer at DAF.......................61

Figure 4-21: Total Reduced Sulfur VS Polymer at Dewatering...................62

Figure 4-22: Scatter plot Total Reduce Sulfur VS Secondary West Odd

Blanket.

Figure 4-23: Scatter plot Total Reduce Sulfur VS Summation of Blanket

Depth....................................................70

Figure 4-24: Scatter plot Total Reduce Sulfur VS Secondary West Odd

Blanket.....................................................73

Figure 4-25: Scatter plot Total Reduce Sulfur VS Summation of Blanket...........73

Figure 4-26: Scatter plot of Total Reduce Sulfur VS RAS East...................74

Figure 4-27: Scatterplot Total Reduce Sulfur VS Secondary West Odd

Blanket ...................................................... 77

Figure 4-28: Scatterplot Total Reduce Sulfur VS Summation of Secondary

Blanket .............................................................

Figure 4-29: Scatterplot Total Reduce Sulfur VS Polymer addition at

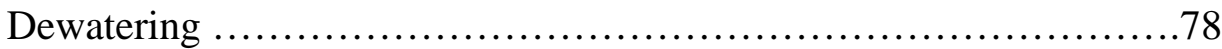

Figure 4-30: Diagram of procedure to get the best model in this research ...........86

Figure 4-31: Total reduced sulfur monitoring VS Total reduced sulfur

Forecasting...............................................90

Figure 4-32: Total reduced sulfur monitoring VS Predicted value..................94

Figure 4-33: Total reduced sulfur monitoring VS Predicted value..................98 


\section{Chapter 1: Introduction}

As this project focuses on total reduced sulfur, the main component of odor released from biosolids after dewatering at the wastewater treatment process, it is necessary to know as much as possible about the source of the odor. In this chapter, an overview of District of Columbia Water and Sewer Authority (DCWASA) is provided. In addition, the scope of this project is outlined, and the project objectives are stated.

\subsection{Section 1 Overview of District of Columbia Water and Sewer Authority}

The Blue Plains Advanced Wastewater Treatment Plant (AWTP) has been a leader in environmental stewardship since it started operations in 1938, with continual upgrades responding to community needs since that time (DCWASA 2005). By 1930, the population of Washington D.C. was approaching 500,000 and the contaminated conditions of the nearby waterways compelled the city to develop a plan to treat wastewater flowing from the sewers (DCWASA 2005). DCWASA treats the combination of storm water and untreated wastewater flowing from the sewers of the Washington area, and discharges it into the Anacostia and the Potomac rivers.

The District of Columbia Water and Sewer Authority’s Blue Plains Plant was known from 1938 to 1996 as the District of Columbia Water and Sewer Utility Administration (Vilalai 2003). At the time, treatment consisted of screening and primary treatment, with secondary treatment and advanced treatment installed in 1959 and 1983, respectively. Due to population growth, the DC government and the US federal government agreed to establish the District of Columbia Water and Sewer Authority as a multi-jurisdictional regional utility on April 18, 1996. At that time, the service area 
covered more than 725 square miles. The installed capacity could treat an average of 370 million gallons per day (mgd) of wastewater, with a treatment peak flow of 740 mgd. DCWASA served more than two million Washington metro area customers in the District of Columbia, portions of Montgomery and Prince George’s Counties in Maryland, and portions of Fairfax and Loudoun Counties in Virginia. The peak wet-weather capacity could treat 1.076 billion gallons a day, with more than 1,200 wet tons per day of biosolids generated and beneficially used (DCWASA 2005).

Wastewater is collected by the DC sewer system and from the Maryland and Virginia suburbs and is delivered to Blue Plains. The agency operates approximately 1,800 miles of sanitary and combined sewers, 22 flow-metering station, nine off-site wastewater pumping stations, and 16 storm water pumping stations within the District of Columbia. Separate sanitary and storm water sewers serve two thirds of the city. In the older portion of the system, primarily in the downtown area, combined sewers (storm water directed into wastewater sewers) are in service.

On an average day, more than 330 million gallons of raw sewage flow into the Blue Plains plant. Based on 2005 projections by the Metropolitan Washington Council of Governments, this figure is expected to rise to the plant's capacity of $370 \mathrm{mgd}$ by 2030 (DCWASA 2005). Currently, the wastewater treatment process at Blue Plains comprises two parts, which a liquid process and a solids (Figure 1-1).

The initial treatment starts as debris and grit is removed and trucked to a landfill. Then the sewage flows into primary sedimentation tanks. In these tanks, more than half of the suspended solids are separated from the liquid. The liquid flows to secondary treatment tanks and is aerated. In secondary treatment, microbes break down organic 
matter and convert ammonia into nitrogen gas. Residual solids are settled out and the water is percolated through sand filters. The sand filters remove remaining suspended solids and associated phosphorus (DCWASA 2005). The water is disinfected, dechlorinated, and discharged into the Potomac river.

Solids and sludge from the primary sedimentation tanks go to the gravity thickener tanks where gravity causes the dense sludge to settle and thicken. This is called gravity sludge thickening. At the secondary sedimentation, some part will be wasted to dissolved air flotation (DAF) thickeners, and another part will be pumped back to secondary aeration tanks which is called return activated sludge (RAS) to maintain a concentration of microorganisms in the aeration tanks (Vesilind 2003). Similarly for the solids from nitrification sedimentation tanks, some parts will be pump back to the nitrification reactor while the rest will be sent to DAF thickeners. In DAF thickeners, DCWASA adds cationic polymer. The main purpose for adding polymer is to combine all small particles for increasing the solid content of sludge and settling easily at the bottom while the air is blown in to float these particles to the surface. Then, a chain pad removes all the floating sludge on the surface of the tanks and sends it to the sludge blending tank system. At the blending tank, gravity and DAF thickened solids are subsequently blended. After the blending, the blended sludge is dewatered by centrifuges and lime is added to remove pathogens. Finally, the organic biosolids are applied to agricultural land. 


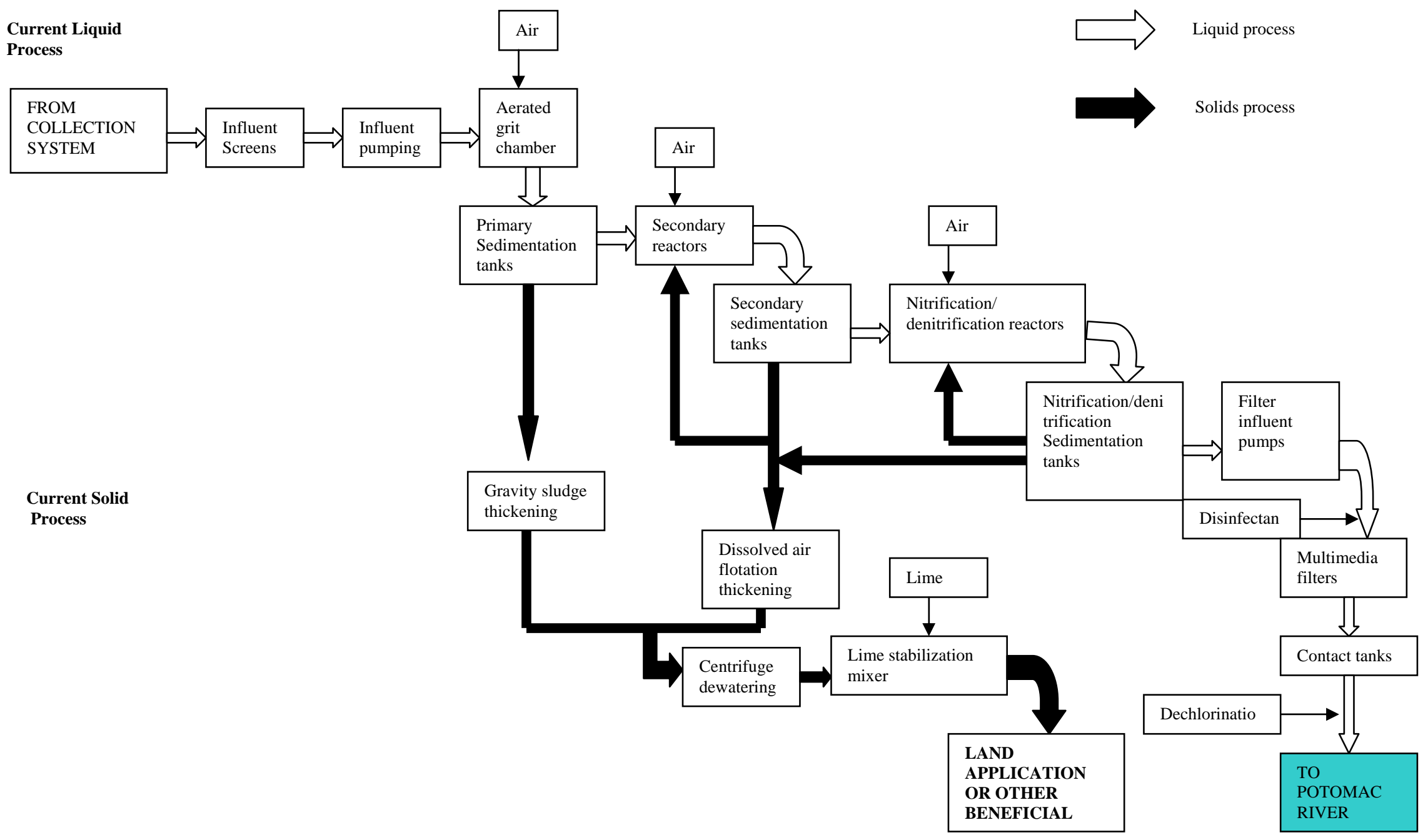

Figure 1-1: DCWASA Process Diagram (DCWASA 2005) 


\subsection{The Scope of the Project}

Nuisance odors are a common occurrence at wastewater treatment plants, biosolids processing facilities, and biosolids recycling locations where proper management and control are not implemented (U.S. EPA 2000). As the result of failure to acknowledge the potential for odors and to work to prevent odor emissions, a plant may be shut down or the finished product not accepted. The odorous compounds that are identified as the most offensive odor are organic and inorganic forms of sulfur, mercaptans, ammonia, amines, and organic fatty acids (U.S. EPA 2000). This research focuses on sulfur compounds which are the main problem for odorous biosolids. At DCWASA, several studies are underway to minimize odors. These include investigating the amount of odor released when different amounts of lime are incorporated into samples (Murthy 2002a), forecasting odor levels for biosolids product based on ambient conditions (Vilalai 2003), prediction of dimethyl disulfide levels from biosolids using statistical modeling (Gabriel, et al. 2005), statistical modeling to forecast odor levels of biosolids applied to reuse site (Gabriel, et al. 2006), and an evaluation of methods for qualifying lime incorporation into mechanically dewatered sludge (North 2003). In addition, other studies have investigated the potential for odor release when a sludge sample is contained in the Teflon tube opened for 30 minutes, 24 hours, and seven days.

An odorous biosolids product, or a biosolids treatment process that results in odor emissions, may be perceived as unhealthy due to the origin of the solids (U.S. EPA 2000). As the result of this problem, the Department of Wastewater Treatment (DWT) of DCWASA tries to control and minimize odor by providing proper facility design, operation, management, control and oversight. Although processes at the plant meet or 
exceed the permit requirements, the biosolids still have odor at the plant and when they are delivered to fields. Many processes are required in producing biosolids products, and it is difficult to operate all such processes with consistency because of technical and operational problems.

As total reduced sulfur released from biosolids is the main problem for odor, this research focuses on monitoring total reduced sulfur, and uses statistical models to forecast amounts of it. In the last few years, DCWASA has researched statistical odor forecasting models to predict the odor levels based on ambient conditions. Gabriel, et al. (2005) identified dimethyl disulfide levels from biosolids by using statistical modeling, and Gabriel, et al. (2006) using statistical modeling to forecast odor levels of biosolids applied to reuse sites. The present research excludes that work by comparing odors with process data before biosolids are delivered to the field.

\section{$1.3 \underline{\text { Research Objectives }}$}

The overall goal of this research is to provide proper information on the control of odors from biosolids production at the Blue Plains plant. At the same time, DWT can apply this research to identify which variables contribute to odor, and thereby adjust the process control and minimize odors. Furthermore, DWT can use this information to predict the amount of total reduced sulfur in biosolids before they are delivered to the field, and help investigate odor problems when residents complain. DWT can also potentially decrease the cost of chemical additions. For example DWT has been adding ferric chloride $\left(\mathrm{FeCl}_{3}\right)$, waste pickle liquor (WPL), sodium hypochlorite (NaOCl), and anionic polymer at the upstream of the primary sedimentation process since 2006; and they have added Cationic Polymer in secondary process, nitrification process, Dissolved 
Air Floatation process and dewatering process. DWT needs to determine which chemicals affect odor in the biosolids product.

To achieve this goal there were three specific objectives for this research.

1. To monitor odors released from biosolids, particularly total reduced sulfur, with a real- time online system.

2. To determine process variables that promote biosolids odor after dewatering.

3. To forecast odors and identify which process variables can be used in statistical modeling.

The ensuing portion of this thesis is organized in four chapters. Chapter 2 presents a literature review on biosolids, odors, and process parameters used in modeling. Chapter 3 provides real- time process data on variables involved in the biosolids process, and realtime monitoring data from $\mathrm{H}_{2} \mathrm{~S}$ analyzers. The process variables are ferric chloride $\left(\mathrm{FeCl}_{3}\right.$ ), waste pickle liquor (WPL), sodium hypochlorite (NaOCl), sludge blanket depth, return activated sludge, percent solid of gravity thickening (GT) in blend tank, percent solid of DAF in blend tank, and blend ratio by volumetric (TPS/ [TPS+TWAS]) or percent of TPS in blend tank and polymer addition. Chapter 4 presents the methodology used to analyze the data by identifying correlations among monitoring data (total reduced sulfur) and process variables. Regression analysis is used to forecast odor. Chapter 5 summarizes and describes the factors affecting odor, how DCWASA can apply this research to minimize odors at Blue Plain, and future work on this research. 


\section{Chapter 2: Literature Review}

This chapter provides basic information on biosolids, odor, and process parameters pertinent to the goals of this project.

\subsection{Sludge and Biosolids}

Sludge is a heterogeneous material and its composition is influenced by many factors, including the sources of wastewater, wastewater and solids treatment operations, seasonal variations, and rainstorms, among others (Robens 1980). The following are the major variations in sludge properties.

The composition and properties of sewage sludge are influenced to the greatest extent by the characteristics of the wastewater entering the wastewater treatment plant and by the treatment processes used. In general, the more industrialized a community is, the higher the possibility of heavy metals causing complications for land application of sewage sludge (U.S. EPA 1995).

Primary sludge, which consists of the normally settable solids in raw wastewater inflow, is generally easiest to dewater. It typically contains 4\% - 5\% solids (North 2003). In addition to free water, and inorganic and organic compounds, it contains a high concentration of microorganisms including large amounts of viruses, bacteria, protozoa, and larger organisms such as parasites (Jeris et al. 1985).

Secondary sludge differs from primary sludge. Its solids concentration is much lower than that of primary sludge (0.5-1.5\%) and it primarily consists of bacteria cells (Metcalf 1991). Another difference is secondary sludge does not produce as much malodor. All secondary sludge is produced by biological metabolism of biological 
oxygen demand (BOD) which is a measure of the oxygen used by microorganisms to compose this waste. In addition, due to the characteristic that it contains high quantities of water trapped in flocs and inside cells, it is difficult to dewater and often requires the addition of conditioners (Jeris et al. 1985; ASCE 2000).

The next sludge is the mixing between primary sludge and secondary sludge, and generally has approximately equal parts of primary and secondary sludge. It also may contain scum, chemical sludge, residuals of advanced treatment processes, and grit. Blue Plains generally blends 50\% DAF thickened secondary sludge with 50\% GT primary sludge in order to optimize dewatering efficiency (DCWASA 2006). Further, Blue Plains adds polymer in order to coagulate the sludge together and help to remove water. However, small quantities of primary scum and biological nutrient removal (BNR) residuals are also mixed into the sludge blend and may affect the sludge properties. Primary scum comprises the floating portion of primary settling and contains high concentrations of fats, oil, and grease (FOG) (Metcalf \& Eddy 2003). For this reason, it contributes to odors (WEF 1995c), has a low biodegradability, can interfere with biological processes (Metcalf \& Eddy 2003), tends to float on wastewater due to its specific gravity (normally 0.95), and coats surfaces causing maintenance problems (North 2003). The composition of BNR sludge is the same as secondary sludge that consists of primary biomass except the different organisms. BNR sludge has various organisms such as autotrophic nitrifiers and a wide range of denitrifying and filamentous organisms (Metcalf \& Eddy 2003). Blue Plain tries to mix both types of residual equally throughout the blend sludge. But it is difficult to maintain this ratio consistency. The properties of sludge are varied because detention times or sludge storage times vary. With increased 
storage, changes could consist of increases in concentrations of BOD/COD and nonsettleable suspended solids, as well as odor intensity (Bruce 1984a). Sludge with short detention times has positive dissolved oxygen concentration. On the other hand, sludge with long detention times has low dissolved oxygen concentration. The varying nature of sludge can cause the problems for other processes such as dewatering, stabilization, and land application (North 2003).

The final sludge from the solid process of wastewater treatment is what industry professionals call, "Biosolids". At Blue Plains, biosolids are created in several ways. One method involves piping wastewater into tanks where heavy organic materials, or solids, settle to the bottom and are scraped away. A second method involves aerating the wastewater in tanks, which allows micro-organisms to consume much of the nutrients and organic matter. The micro-organisms settle to the bottom and are removed as solids. A third method combines iron with phosphorus in the wastewater. Once again, this material settles to the bottom and is removed.

The various settled solids are ultimately processed by lime stabilization treatment methods at Blue Plains (DCWASA 2005). The process consists of mixing a blend or dewatered solids with lime to eliminate unwanted organism, which is called limestabilized biosolids.

The term biosolids is conventionally reserved for sewage sludge that has been treated and meets strict federal and state requirements, which reduce the risks of landapplied biosolids to human health and environmental quality (WEF 1995b). The benefit of biosolids is that it is an abundant source of food for microorganisms providing proteins amino acids and carbohydrates (U.S. EPA 2000). In addition, biosolids contribute organic 
material to soil that encourages moisture retention, provides essential micro-nutrients to crops, and act as a liming agent for agricultural land.

Biosolids have numerous beneficial uses including agricultural land application, strip-mined land reclamation, landfill cover, forest application, park applications and even residential home and garden application (U.S. EPA 1995). Biosolids must meet numerous federally mandated requirements in order to be land applied. The two main regulations for biosolids are pollutant limits and pathogen level limits (WEF 1995a; Krogmann et al. 1999). The most concern for pollutant limits focuses on heavy metals, organic chemicals, the protection of the environment, and human health from high level pollutant concentrations and cumulative loadings. Therefore, the key to any successful wastewater biosolids program is stabilization. The term "stabilization” has not had an exact and accepted definition of biosolids stability (Bruce 1984a). The evaluation of stability is especially difficult considering the various types of sludge that are produced and the wide range of different procedures used to stabilize them (Switzenbaum et al. 1997).

At the present, there are many methods used to stabilize sludge, but the goals are almost the same: producing a material that is safe and inoffensive (Bruce and Fisher 1984b). According to Hartenstein (1981), three factors can be used to assess whether a material is stable: odor production, pathogens, and microbial metabolism. Unstabilized sludge will support the metabolism of high amounts of microbial activity. In contrast, stabilized sludge will not putrefy and cause odor problems. In addition, the concentrations of pathogens in stabilized sludge are low and consequently its potential to harm the environment or human health is low (Hartenstein 1981). Blue Plains adds lime 
in order to kill pathogen, but the addition of lime to sludge results in a variety of changes to the physical, chemical, and microbiological characteristics of sludge. Change in $\mathrm{pH}$ and temperature are the primary cause of stabilization and pathogen reduction. Lime stabilization can be as or more effective than other stabilization processes (U.S. EPA 1979). The addition of $\mathrm{Ca}(\mathrm{OH})_{2}$ can raise $\mathrm{pH}$ levels to as high as 12.5 (WEF 1995a). Therefore, to achieve adequate $\mathrm{pH}$ increases, enough lime must be added to combine with these reactants and increase the $\mathrm{OH}^{-}$concentration.

Biosolids can be categorized into two classifications, Class A and Class B, depending on the pathogens in them. Class A biosolids have more stringent requirements for pathogen reduction, and therefore have less application restrictions. Class A biosolids have passed addition treatment and have below-detectable pathogen levels, so they can be applied directly to the land without field restrictions and also sold as fertilizer. Class B biosolids have lower level requirements for pathogen reduction but more stringent application restrictions. Class B biosolids have to be treated for reducing pathogens before application. The regulations for land application of biosolids are described in section 40 of the Code of Federal Regulations, part 503 (U.S. EPA 1979).

\subsection{Odorous Compound and Measurement at Blue Plain}

Odorous substances that are emitted from domestic wastewater collection and treatment processes include both inorganic gases and organic gases and vapors. Inorganic gases include hydrogen sulfide and ammonia (WEF 1995c). Although both classes of compounds typically are produced as a result of biological activity, organic vapors may also originate from direct discharge of chemical wastes. Many of these odorous substances result from the anaerobic decomposition of organic matter containing sulfur 
and nitrogen. Since the odor threshold for ammonia is about three odors of magnitude higher than for hydrogen sulfide it is the latter which is usually mostly responsible for odor problems at waste water treatment plants (WWTPs), and the main source of hydrogen sulfide at WWTPs is its natural formation by the decomposition of human waste and other organic products (Terry 2001). In addition, $\mathrm{H}_{2} \mathrm{~S}$ is a highly toxic compound, which affects cardiovascular and respiratory human organs (Terry 2001). However, odors may also be generated by aerobic decomposition and solids-processing methods that include heat treatment (WEF 1995c). For WWTPs, there is mixture of odorants such as volatile sulfur compounds (VSCs), volatile nitrogenous compounds (VNCs), and volatile fatty acids (VFAs). Odor reduction is the priority goal of sludge stabilization that is critical for public acceptance of the biosolids stabilization program. Because microorganisms produce high levels of odorous gases as they convert raw sludge into a more stable material, odor reduction is related to biosolids stabilization (Switzenbaum et al. 2000). However, quantifying odor emissions can be complex and subjective, because biosolids odors comprise numerous organic and inorganic compounds that are affected by the sludge composition, storage time, stabilization method, and other factors.

Odor emissions are the complex mixture of various gases, the relative importance of which depends on the stabilization technique. Hydrogen sulfide is the most common malodorous compound produced by biosolids (WEF 1995a). $\mathrm{NH}_{3}$ is also commonly produced in biosolids, especially in lime-stabilization, but this project focuses on only hydrogen sulfide. VSCs have a very low threshold odor concentration and are the common and malodorous gas produced under sulfate reducing and other anaerobic 
conditions. VSCs are composed of hydrogen sulfide $\left(\mathrm{H}_{2} \mathrm{~S}\right)$, carbon disulfide $\left(\mathrm{CS}_{2}\right)$, dimethyl sulfide (DMS), dimethyl disulfide (DMDS), methyl mercaptan (MM), and ethyl mercaptan (EM) (Sekyiamah 2005). Microorganisms form a variety of organic sulfur compound during assimilative sulfate reduction. $\mathrm{HS}^{-}$is formed during the decomposition of this organic sulfur via the processes of putrefaction and desulfurylation (Madigan et al. 1997). Normally, organic sulfur has many different forms: sulfate $\left(\mathrm{SO}_{4}{ }^{2-}\right)$, sulfite $\left(\mathrm{SO}_{3}{ }^{2-}\right)$, thiosulfate $\left(\mathrm{S}_{2} \mathrm{O}_{3}{ }^{2-}\right)$ and sulfide $\left(\mathrm{S}^{2-}\right) . \mathrm{SO}_{4}{ }^{2-}$ is the most oxidize state and $\mathrm{H}_{2} \mathrm{~S}$ is the most reduced state. Therefore, if anaerobic conditions are present, sulfide $\left(\mathrm{S}^{2-}\right)$ will occur, but in different species depend on function of $\mathrm{pH}$ which can be seen in the following diagram:

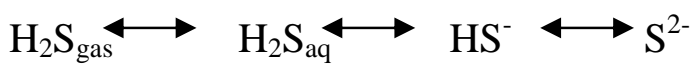

These species combine to become total reduced sulfur. In addition, hydrogen sulfide is also formed by dissimilatory sulfate reduction, during which obligate anaerobes use oxidized sulfur compounds as a final electron acceptance during their oxidation of organic compounds (North 2003). The organisms which carry out this process are known as sulfate-reducing bacteria. Dissimilatory reduction reduces sulfate species and produces more sulfide than the bacteria require for cell synthesis. Typically $\mathrm{H}_{2} \mathrm{~S}$ concentration at WWTPs fence line does not exceed 10-30 part per billion (ppb) (Terry 2001).

Many methodologies are used to measure $\mathrm{H}_{2} \mathrm{~S}$, such as Gas Chromatography (GC). Chemical detection tubes can also be used to measure several malodorous gases, including $\mathrm{H}_{2} \mathrm{~S}$ (WEF 1995a), but detection tubes can not measure $\mathrm{H}_{2} \mathrm{~S}$ at low concentrations. Another method, which is used widely, is portable $\mathrm{H}_{2} \mathrm{~S}$ analyzers. Blue Plains has many projects that use these instruments to monitor $\mathrm{H}_{2} \mathrm{~S}$. In the present project, 
devices come from the Detection Instrument Company. These instruments measure $\mathrm{H}_{2} \mathrm{~S}$ and other reduced sulfur compound concentrations with in the range $10 \mathrm{ppb}$ to $50 \mathrm{ppm}$.

\subsection{Process Variables}

The followings are the Blue Plains process variables that are expected to affect odor released from biosolids. Odor from sludge is a combination of several factors, such as the constituents of the sludge on that day, the chemical compounds added in the process, the biological activities of microorganisms in the sludge during the liquid and solid phases, the detention time in each phase, and the efficiency of the equipment in the process such as the number of centrifuges in dewatering process (Vilalai 2003).

\subsubsection{Ferric Chloride $\left(\mathrm{FeCl}_{3}\right)$ addition}

Ferric chloride $\left(\mathrm{FeCl}_{3}\right)$ is a chemical compound consisting of two elements; irons (Fe) and chlorine (Cl). It is a flocculant which makes tiny particles clump together so they can be removed from wastewater. Ferric chloride is recycled from a liquid left over from steel-making. The following benefits of ferric chloride addition have been noted: (WEF 1995c)

- Increased BOD and total suspended solids (TSS) removal across primary clarifiers believed to be the effect of "sweep flocculation."

- Lower influent phosphorous concentrations

- Better settling solids in secondary clarifiers and digester.

- Solids conditioning requiring fewer polymers for dewatering operations. At DCWASA, ferric chloride is added to the primary settling process, and the main purpose is to remove nutrients such as phosphorous, or enhance settling 
performance (WEF 1996). When wastewater is treated and discharged to the Potomac River, phosphorous can stimulate algae growth in the river. Therefore, it is important to remove phosphorous before releasing wastewater to the river. Ferric chloride addition will be based on the decision of operators, therefore this variable should be included in correlation analysis because it is the main chemical added into primary process (Vilalai 2003).

\subsubsection{Waste Pickle Liquor (WPL) addition}

Pickle liquors are acid solutions used in steel manufacturing to clean steel and remove mill scale in preparation for other processes (WEF 1995c). It depends on the types of steel and metal that have been cleaned in the acid at the steel mill, the acid contains varying concentrations of metals. Pickle liquors that have been used to clean stainless steel stock often contain elevated concentrations of chromium and nickel. Many other metals can be present. Thus, heavy metal and iron concentrations can fluctuate over considerable ranges, and the free acid content of pickle liquors can vary significantly. As it is a waste product, it is usually cheaper than prepared solutions. Waste Pickle Liquid (WPL) is added to the secondary process in order to remove phosphorous from the wastewater after passing the primary process, and can decrease hydrogen sulfide in the wastewater system.

\subsubsection{Sodium Hypochlorite (NaOCl) Addition}

Sodium Hypochlorite is a oxidizing chemical compound with the formula $\mathrm{NaOCl}$. A solution of sodium hypochlorite is frequently used as a disinfectant and bleaching agent. It may be prepared by absorbing chloride gas in cold sodium hydroxide solution. The 
commercial solutions always contain significant amounts of sodium chloride (common salt) as the main byproduct. A $12 \%$ solution is widely used in waterworks for the chlorination of water. For shock chlorination of wells or water systems, a $2 \%$ solution of household bleach is used. For larger systems, high-test hypochlorite is more practical because lower rates can be used. The alkalinity of the sodium hypochlorite solution also causes the precipitation of minerals such as calcium carbonate, so that shock chlorination is often accompanied by a clogging effect. The precipitate also preserves bacteria, making this practice somewhat less effective. Another benefit for sodium hypochlorite is to reduce odor from the domestic wastewater in the upstream, and can be used for disinfectant at the effluent. For these reason, DCWASA has added $\mathrm{NaOCl}$ at the primary process for odor control and at the contact tanks for dechlorination before discharge to the Potomac River.

\subsubsection{Polymer Addition}

Wastewater treatment involves solid-liquid separation using polymeric flocculants. Polymers are commonly applied for sludge conditioning in elutriation, thickening, and dewatering; enhancement of alum coagulation/flocculation; and improvement of alum, ferric, or calcium precipitation of phosphorous in wastewater (Churchill 1977). There are three types of polymer: anionic, cationic, and non-ionic (WEF 1996). Cationic and other polymers are coagulant aids used in conjunction with other inorganic coagulants. The long chains of positively charged polymers can help to strengthen a floc making it larger, faster settling and easier to filter out. The main advantages of polymer coagulants and aids are that they do not need an alkaline solution to work, and they produce less settled waste than other coagulants, which can reduce operating costs. Before 2004, DCWASA 
added polymer only at dewatering process and dissolved air floatation (DAF) processes. According to Murthy (2004) polymer is more effective than ferric chloride for chemical coagulation at high surface overflow rates. Therefore, DCWASA now adds polymer in primary process, secondary process, nitrification process, dewatering process and dissolved air Floatation (DAF) process in order to improve clarification or hold sludge particles together. Several studies have shown that polymer added into sludge is a main factor that increases biosolids odor, especially amine product, e.g., Trimethyl Amine (TMA) (Kim 2001a). According to Kim (2001a), microbial activity in waste activated sludge and degradation of polymer added in DAF results in the production of TMA. Therefore DAF is expected to be the important source of TMA.

\subsubsection{Sludge Blanket Depth}

Microorganisms consume organic matter in the aeration tank, after this process the wastewater is sent to secondary settling tank to separate suspended solids by gravity. The depth of the suspended solids in this tank is called the sludge blanket depth. In order to balance microorganisms in biological process, some sludge will be returned to the aeration tank (return activated sludge) while the remaining sludge (waste activated sludge) is sent to dissolved air floatation thickeners (Vilalai 2003). Research at DCWASA has shown that the greater secondary blanket depth, the greater the biosolids odors. The rationale is that higher blanket depth indicates more retention time for activated sludge in the settling tanks. The greater retention time of waste activated sludge influences the development of anaerobic conditions for microorganisms in the tank and reduces the oxidation reduction potential (ORP) the greater the production of reduced sulfur compound (Vilalai 2003). 


\subsubsection{Return Activated Sludge (RAS)}

In secondary treatment process, the effluent from secondary aeration tank flows through channels to sedimentation tank separating water and solids. For settled solids, some part will be wasted to the blend tank but another part will be pumped back to the aeration tank. The settled solids that are pumped back to the aeration tank are called return activated sludge (RAS). The purpose of RAS is to keep or maintain an adequate concentration of activated sludge in the aeration tank. Typically, RAS concentrations range from 4,000 to 12,000 mg/L (Metcalf \& Eddy 2003).

\subsubsection{Blend Ratio by volumetric (TPS/ [TPS+TWAS]) or \% of TPS in Blend} Tank)

Referring to Section 2.1., blend ratio is the mixing between total primary sludge (TPS) and total waste activated sludge (TWAS), which are the combination of sludge from secondary process, nitrification, and de-nitrification. Both sludges are mixed together in the blending tank. This can be calculated by volume of gravity thickener of primary sludge divided by volume of dissolved air floatation of secondary sludge (TPS/TWAS). The normal range of the ratio is from 0.3 to 0.7 (Tolbert 2003). The Blend ratio in this research is the ratio of volumetric of TPS and TWAS in blend tank which can be calculated by percent of volume of TPS in the blend tank.

$$
\text { TPS/ (TPS+TWAS) }
$$

According to Vilalai (2003), sludge from the primary process is highly condensed and considered to be the source of food for microorganism in waste activated sludge. Therefore, a higher percentage of TPS in the blend means that microorganisms have more food relative to their population. For instance, a higher percent TPS in a blend means the 
biosolids after dewatering will have more microorganisms. Therefore, percent of TPS in blend may be a factor that contributes to odor level in biosolids.

\subsubsection{Percent Solid of Gravity Thickening (GT) in Blend}

From section 2.3.7, the blend tank is the mixing between TPS and TWAS. Gravity thickening (GT) is one of the most common methods used and is accomplished in a tank similar in design to a conventional sedimentation tank (Metcalf \& Eddy, 2003). In the blend tank, it is necessary to know the percent of solids of TPS and TWAS. DCWASA tries to maintain the percent of solids of TPS to be $6-10 \%$, and TWAS to be at $4 \%$. The percent of solids of GT is the dry tons of solids that come from primary sludge before mixing in the blend tank:

[(Flow of TPS) X (average of \% solids of TPS)

Dry ton of solids of DAF can be calculated the same way by using flow of TWAS times the average of \% solids TWAS. Therefore, the total solids in blend will be the summation of dry tons of solids of GT and DAF:

[Dry ton of solids of GT X 100/ (Dry ton of solids of GT + Dry ton of solids of DAF)] (3) 


\section{Chapter 3: Process Variables Data and Monitoring Data}

This chapter presents data for the process variables most significant for total reduced sulfur level, and data for total reduced sulfur from the real-time monitoring system.

\subsection{Process Variables Data}

From section 2.3, the following process variables may affect total reduced sulfur level:

1. Ferric Chloride $\left(\mathrm{FeCl}_{3}\right)$ addition

2. Waste Pickle Liquid (WPL) addition

3. Sodium Hypochlorite addition

4. Polymer addition

4.1 Polymer Addition at Primary Process

4.2 Polymer addition at Secondary Process

4.3 Polymer addition at Nitrification Process

4.4 Polymer addition at Dewatering Process

4.5 Polymer addition at DAF

5. Sludge Blanket Depth

6. Return Activated Sludge (RAS)

7. Blend Ratio by volumetric (Percent of TPS in Blend tank)

8. Percent Solid of GT in Blend

Data on these process variables were collected from February to August 2006 at the same time as data for odor. Due to operational problems, some process data were 
missed, and on some days sludges was fed to process trains that were not monitored. Therefore, only parts of the process data have been continuously monitored, and total reduced sulfur is collected every 30 minutes over 24 hours. Between April 26 and May 23, no processes were monitored because the devices were sent to be calibrated at the manufacturer.

\subsubsection{Ferric Chloride Addition}

Blue Plain adds $\mathrm{FeCl}_{3}$ in the primary settling process in order to remove phosphorous, and enhance settling performance. Iron (III) coagulants are also sometime used, because they work over a larger $\mathrm{pH}$ range, have lower costs, and in some cases remove natural organic contaminants better. However, phosphorous stimulates algae growth, adding $\mathrm{FeCl}_{3}$ is necessary to remove this nutrient. $\mathrm{FeCl}_{3}$ makes phosphorous precipitate from wastewater (Metcalf \& Eddy 1991). Because ferric chloride affects primary settling, it may affect the odor level of biosolids. The amount of ferric chloride usage at DCWASA is shown in Figure 3-1.

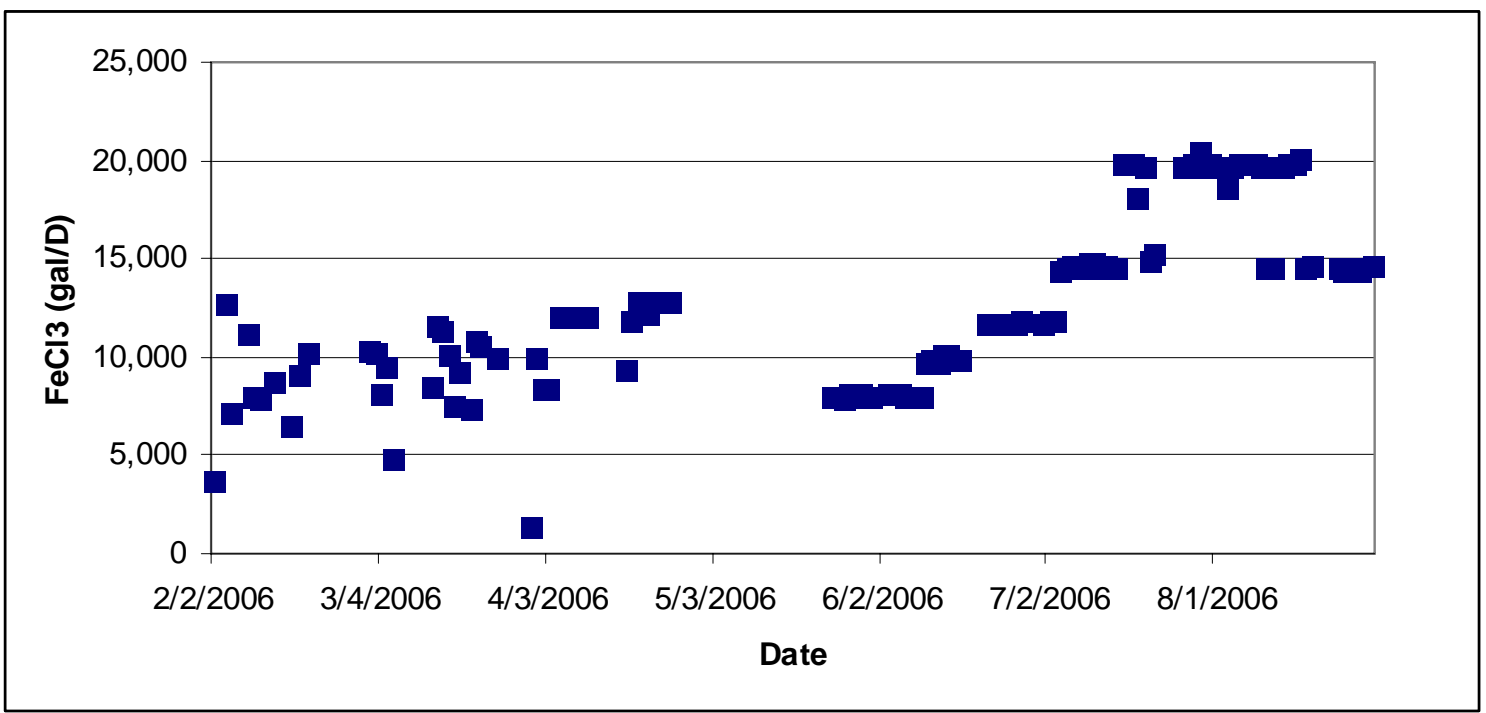

Figure 3-1: Ferric Chloride Addition at primary process 


\subsubsection{Waste Pickle Liquor (WPL) Addition}

Normally DCWASA adds waste pickle liquor (WPL) in the secondary sedimentation process to further to remove phosphorous and decrease odor. In January 2006, DCWASA also began adding WPL in the upstream primary process system as well. However WPL was not added upstream from July 14 to August 16 due to manufacturer problems. WPL usage can be seen in Figure 3-2.

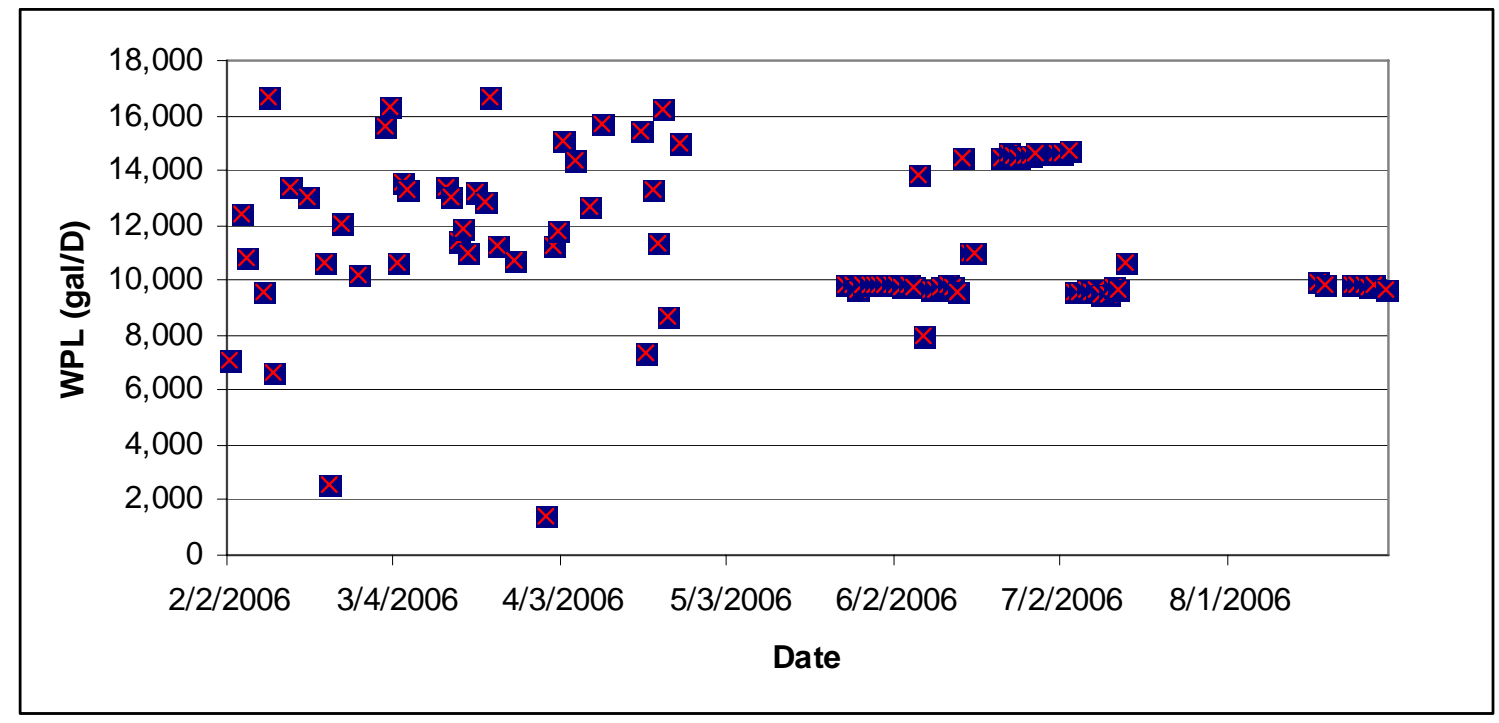

Figure 3-2: Waste Pickle Liquor (WPL) Addition at primary process

\subsubsection{Sodium Hypochlorite Addition}

DCWASA adds sodium hypochlorite ( $\mathrm{NaOCl})$ to perform two different roles in different locations. First, they add sodium hypochlorite upstream of the primary process, which is the same location for Ferric chloride and WPL, in order to reduce odor upstream of the process. Secondly, they add sodium hypochlorite at the contact tank after the multimedia and before release to the Potomac River for the disinfection or dechlorination. NaOCl 
may be another variable that can affects odor. The amount of NaOCl used in primary process can be seen in Figure 3-3.

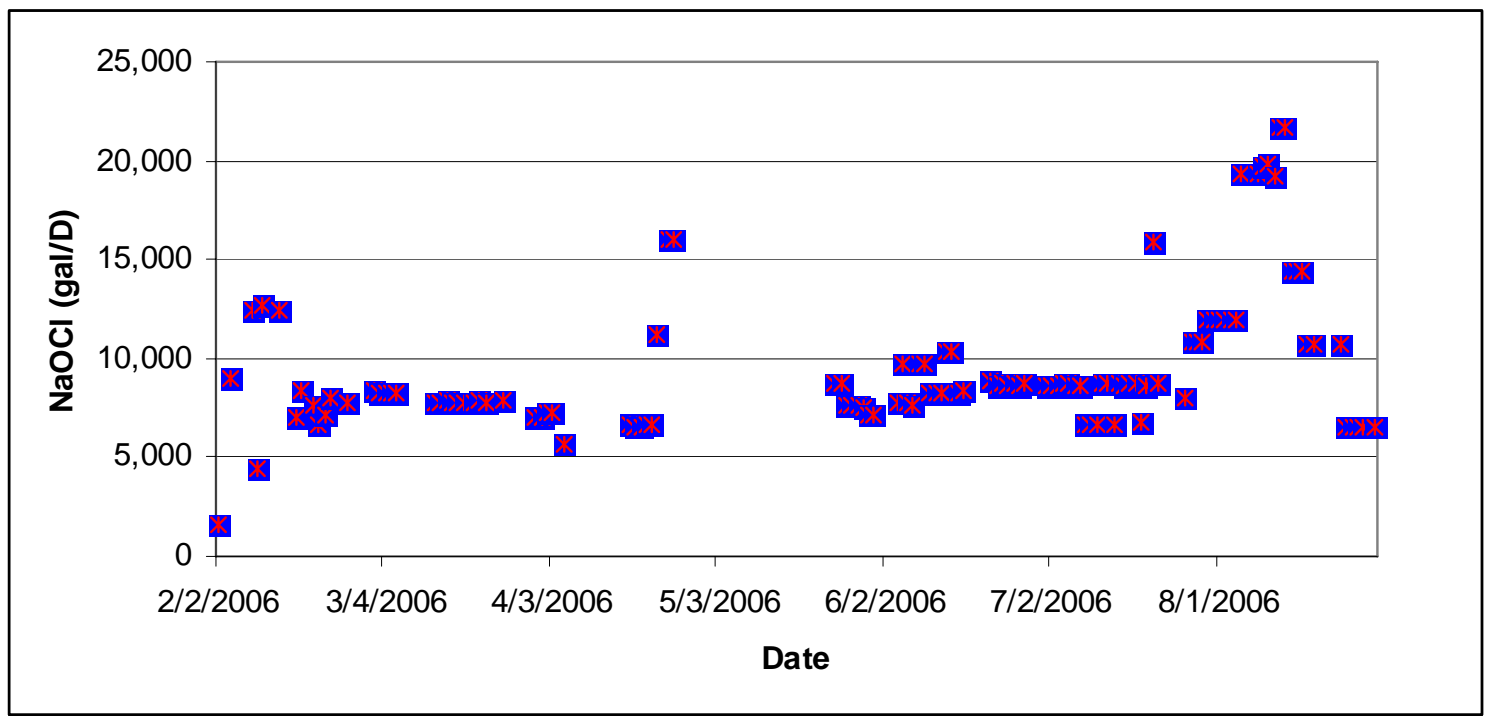

Figure 3-3: Sodium Hypochlorite Addition

\subsubsection{Polymer Addition}

Polymer is added to wastewater for coagulation and sludge conditioning. Since 2004, DCWASA has added polymer to all processes (primary process, secondary process, nitrification process, DAF, and dewatering process) in order to increase flocculation. According to the recent research, anionic polymer is more effective than ferric chloride for chemical coagulation at high surface overflow rates (DCWASA 2006). For this reason, anionic polymer is now added to the primary process. The polymer usage in primary process, secondary process, nitrification process, DAF, and dewatering process can be seen in Figure 3-4 to Figure 3-8, respectively. 


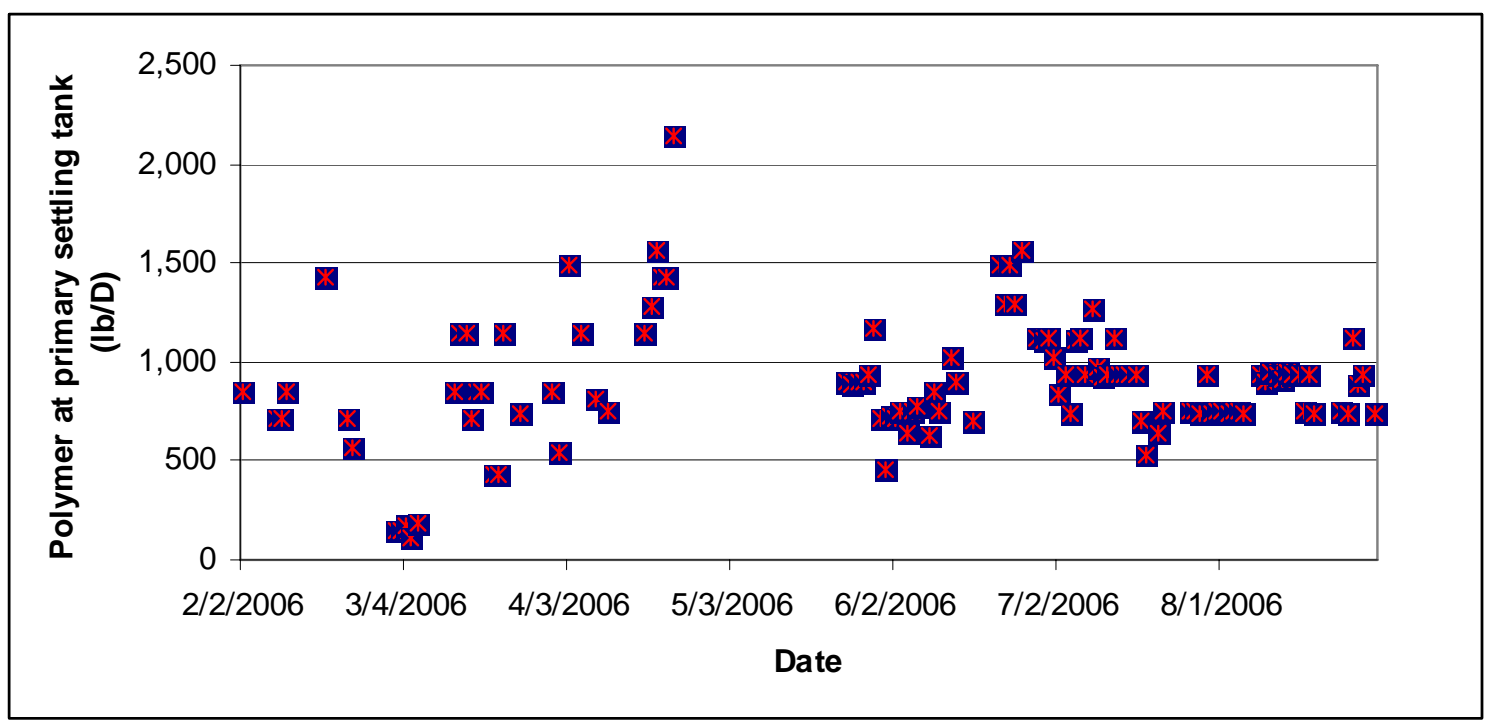

Figure 3-4: Polymer Addition at primary settling tank

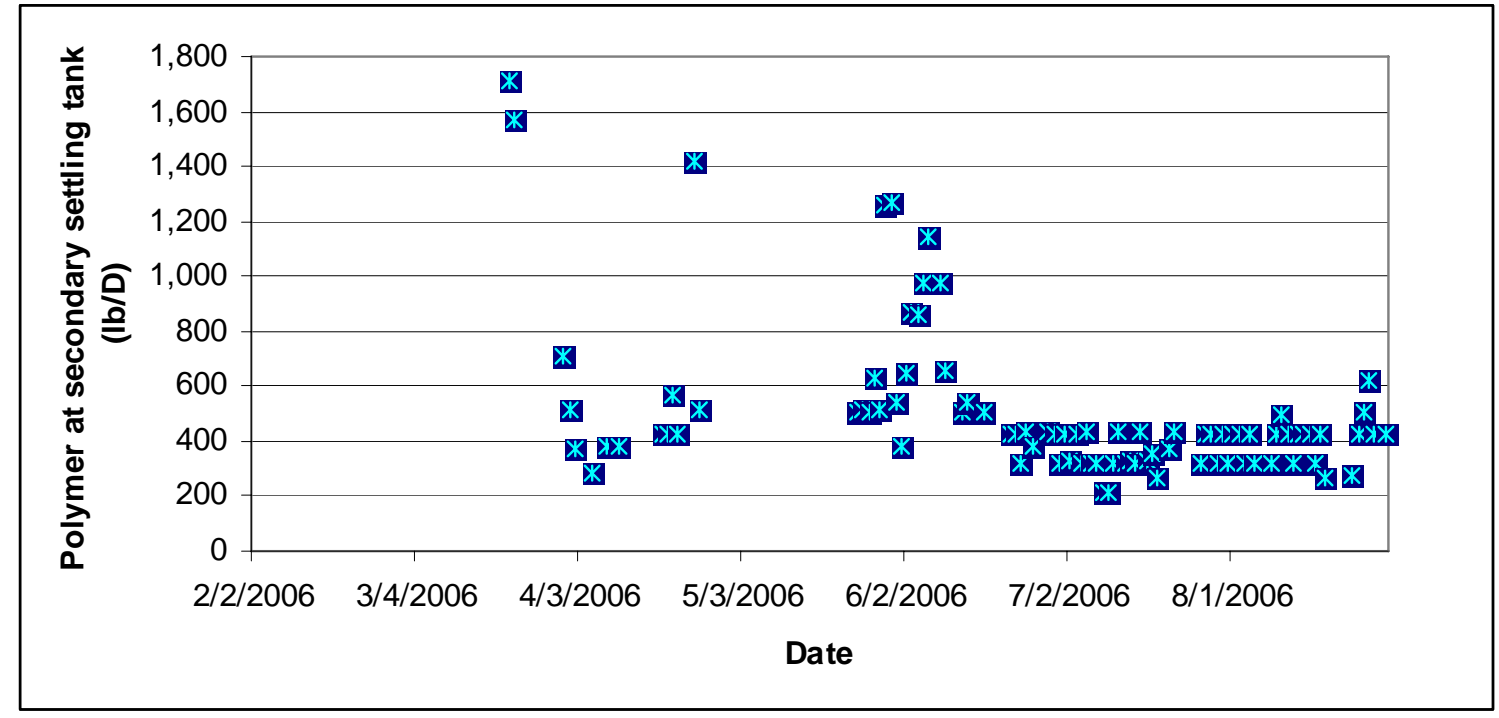

Figure 3-5: Polymer Addition at secondary settling tank 


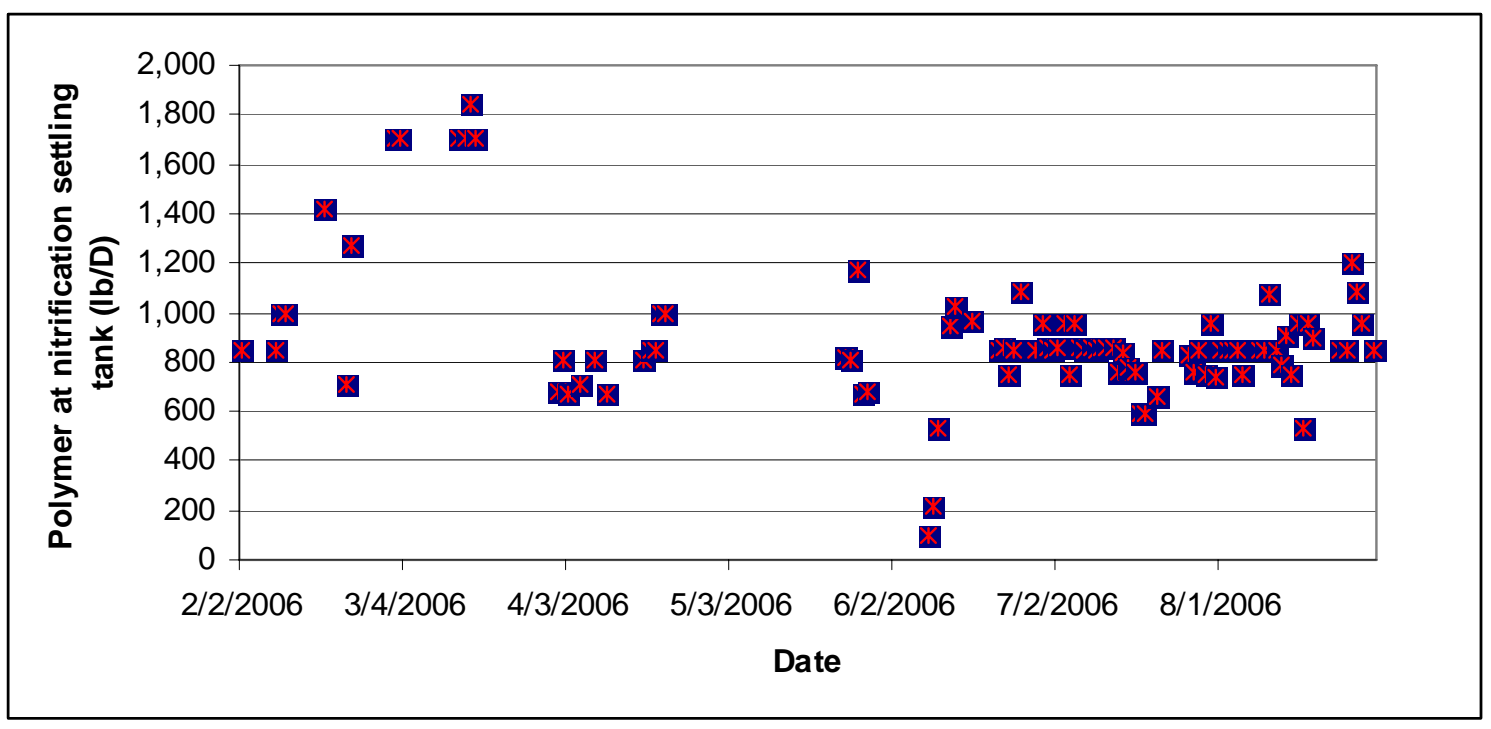

Figure 3-6: Polymer Addition at nitrification settling tank

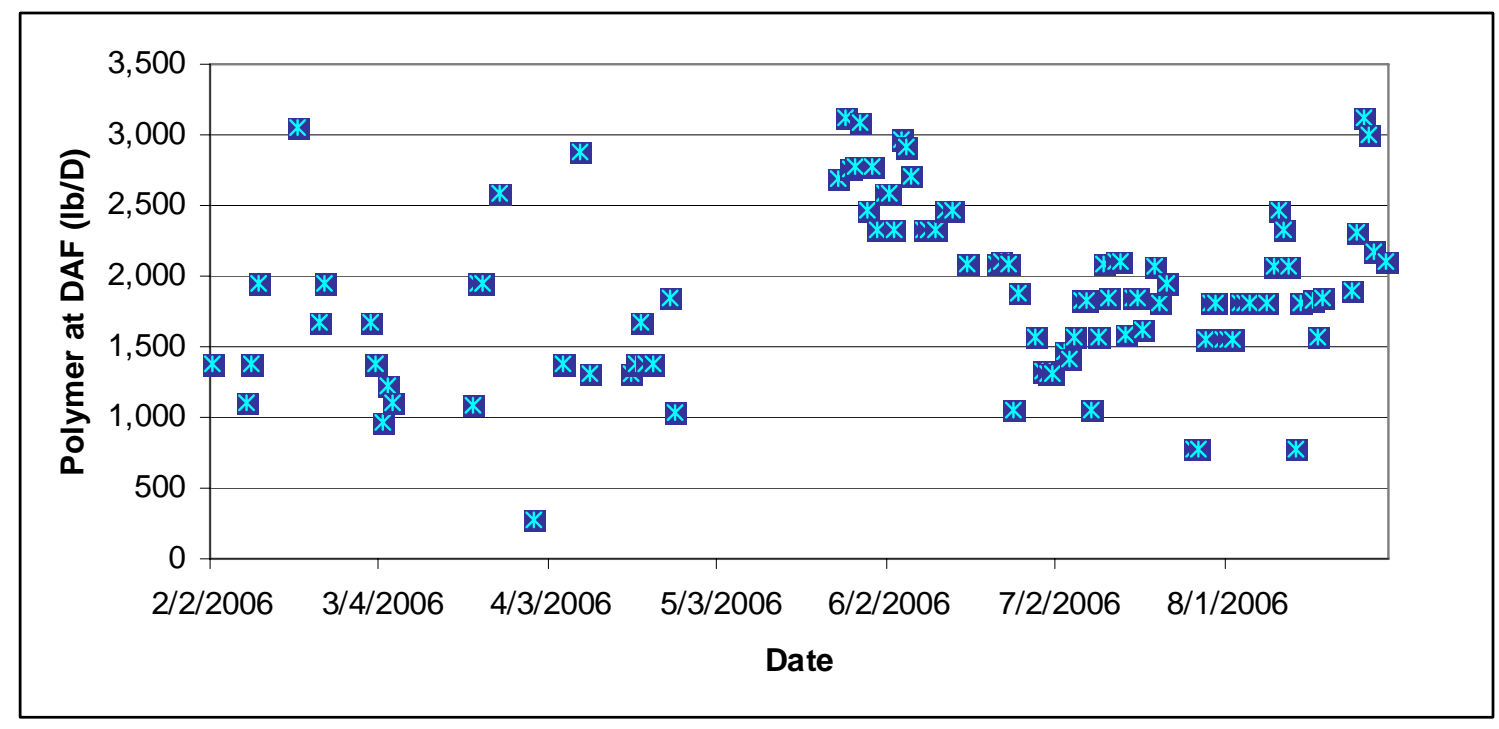

Figure 3-7: Polymer Addition at DAF Process 


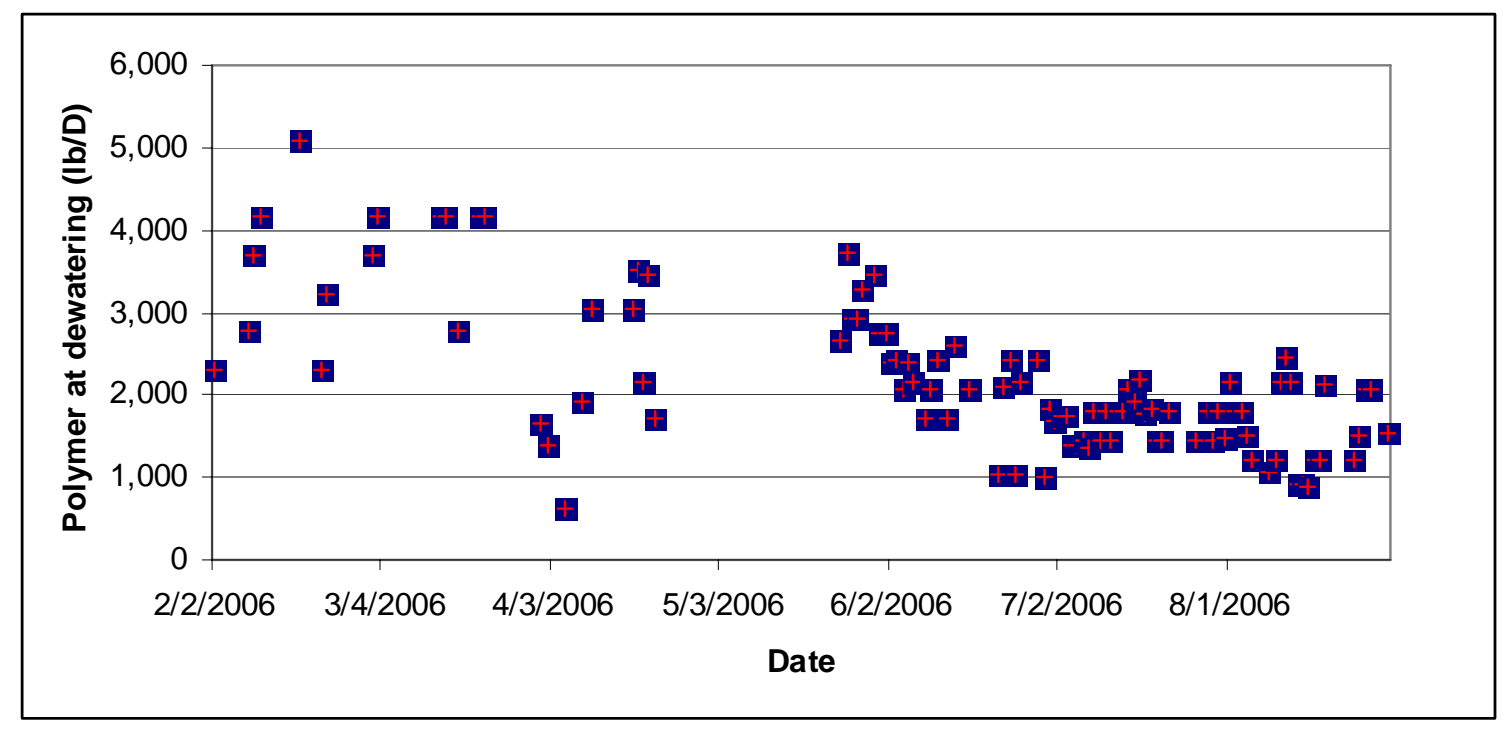

Figure 3-8: Polymer Addition at Dewatering Process

\subsubsection{Sludge Blanket Depth}

The secondary process at Blue Plain splits the flow into two sides, west and east.

DCWASA tries to maintain the retention time of secondary sludge in the blankets no shorter than two hours, and no longer than one day (Peot 2006). The height of the sludge blanket depth depends on flow and detention time. The longer the retention time, the greater the depth of the sludge blanket, and the greater the production of odor (Vilalai 2003). The height of sludge blanket depth from both sides can be seen in Figure 3-9 and Figure 3-10. 


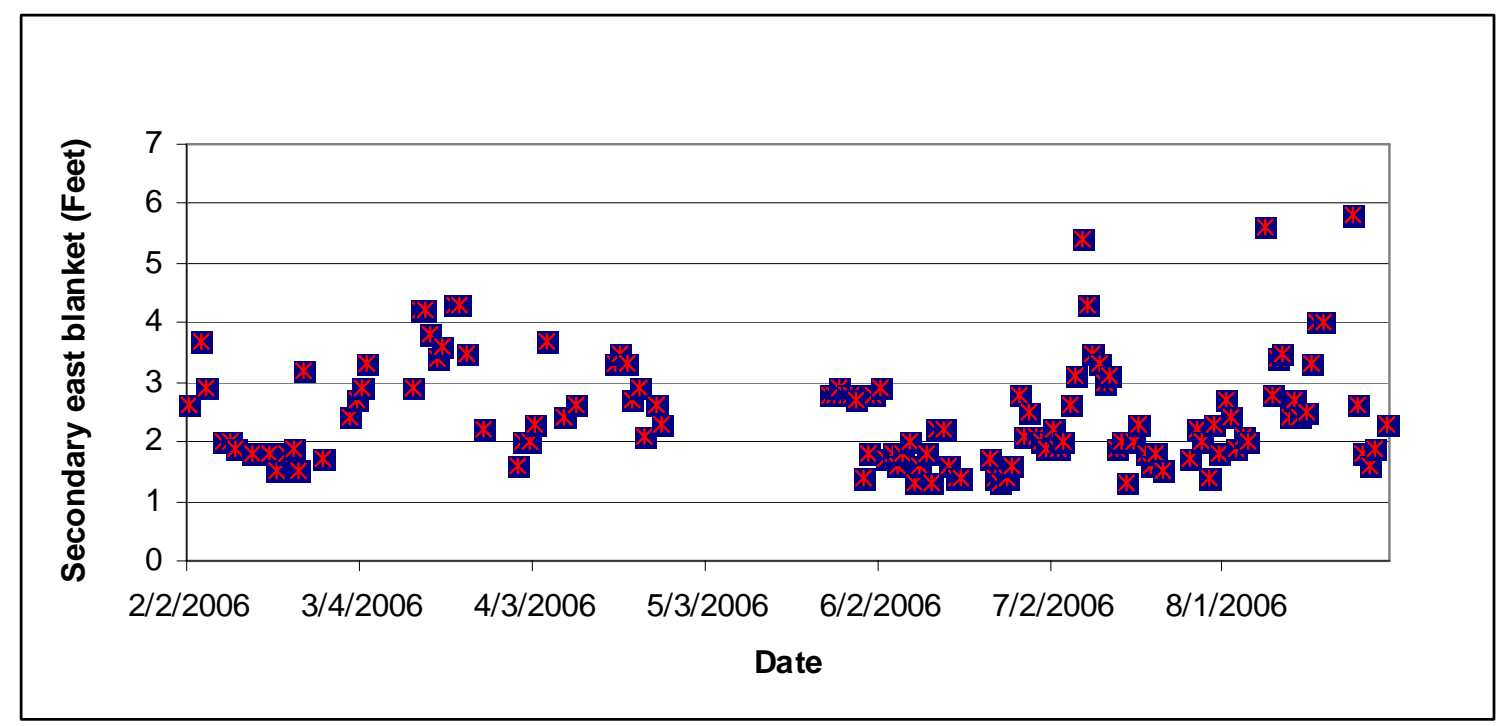

Figure 3-9: Secondary Sedimentation East Blanket Depth

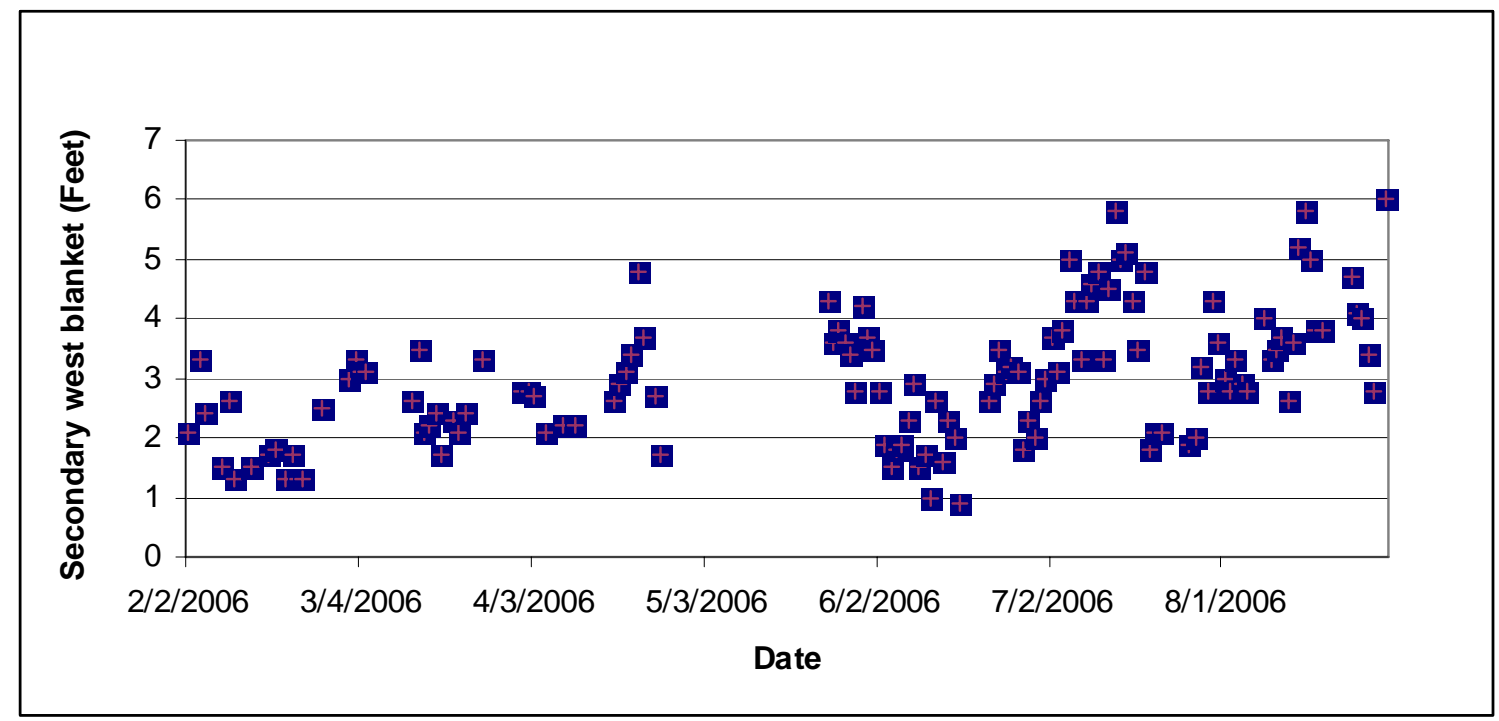

Figure 3-10: Secondary Sedimentation West Blanket Depth 


\subsubsection{Return Activated Sludge (RAS)}

A reviewed above Section 2.3.6 and Section 3.1.5 RAS of each side is pumped back from the secondary sedimentation tanks to the secondary aeration tank. RAS concentration in each side can be seen in Figure 3-11 and Figure 3-12.

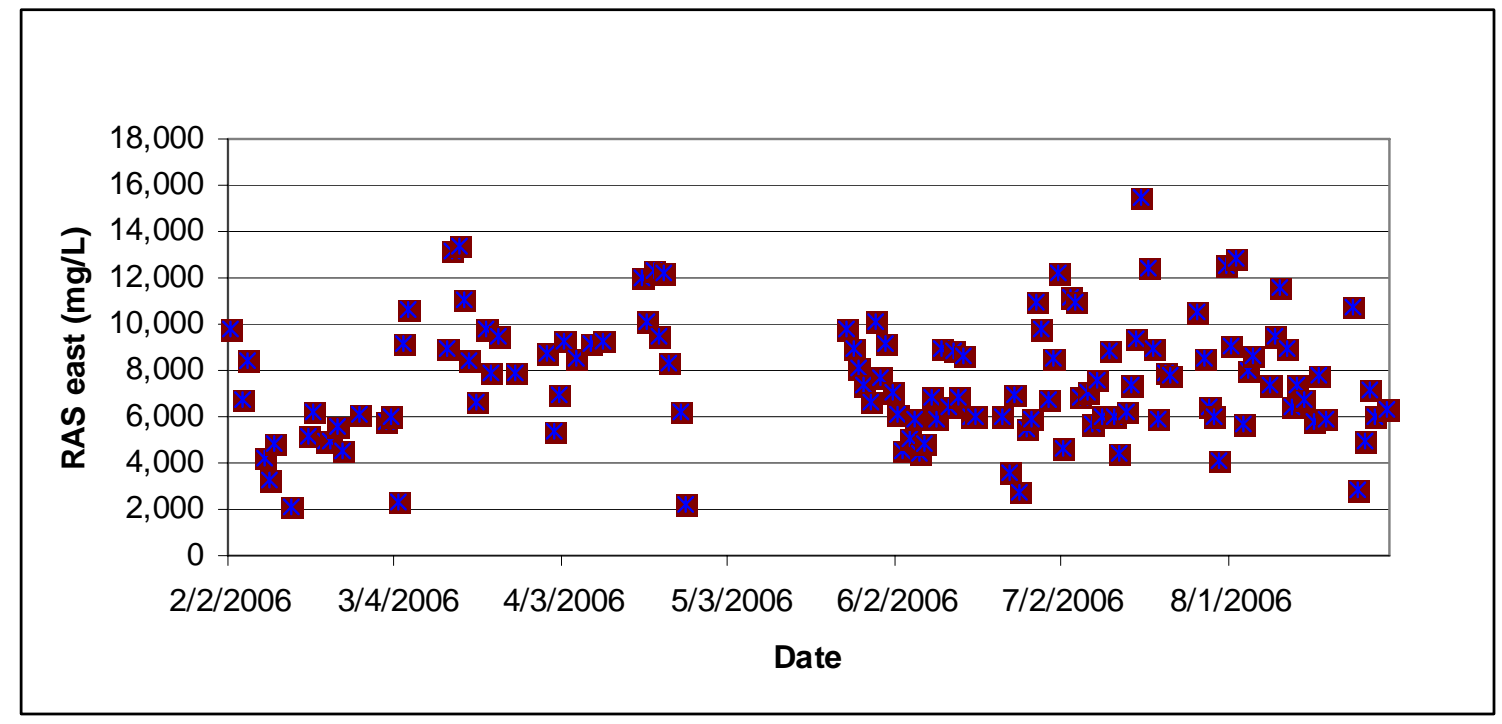

Figure 3-11: Return Activated Sludge from Secondary East

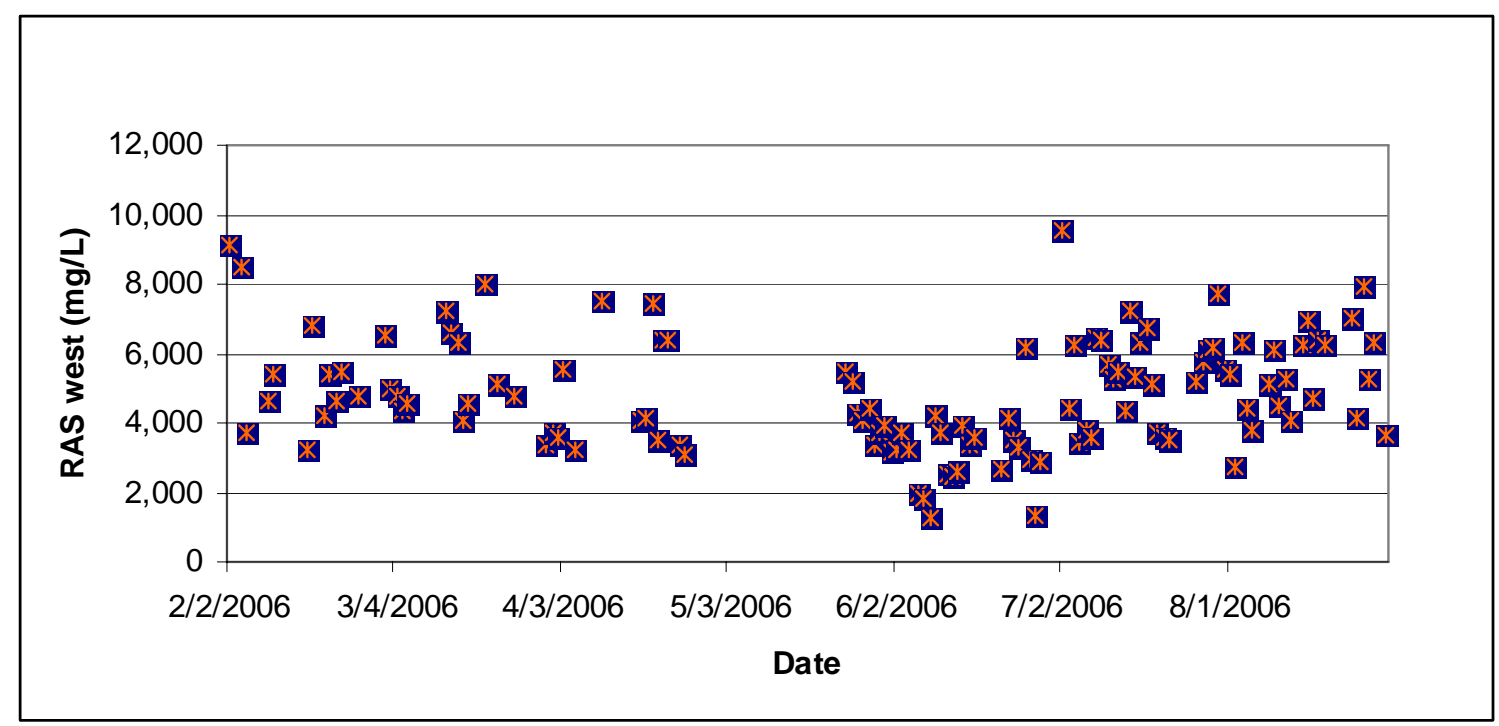

Figure 3-12: Return Activated Sludge from Secondary West 


\subsubsection{Blend Ratio (Percent of TPS by volume in Blend Tank)}

The blend tank mixes sludge from the TPS and TWAS. Thus the blend ratio is the volume of TPS divide by the summation of TPS and TWAS. According to Murthy (2006), the volumetric blend ratio is inaccurate and should be replaced by the blend ratio based on percent solids (section 3.1.8). But for operational reason, it's easy to control the blend ratio by the flow of TPS and TWAS. The volume of both TPS and TWAS, percent of TPS in blend tank (Blend Ratio by volumetric) and percent of TWAS in blend tank can be seen Figure 3-13, Figure 3-14, Figure 3-15 and Figure 3-16, respectively.

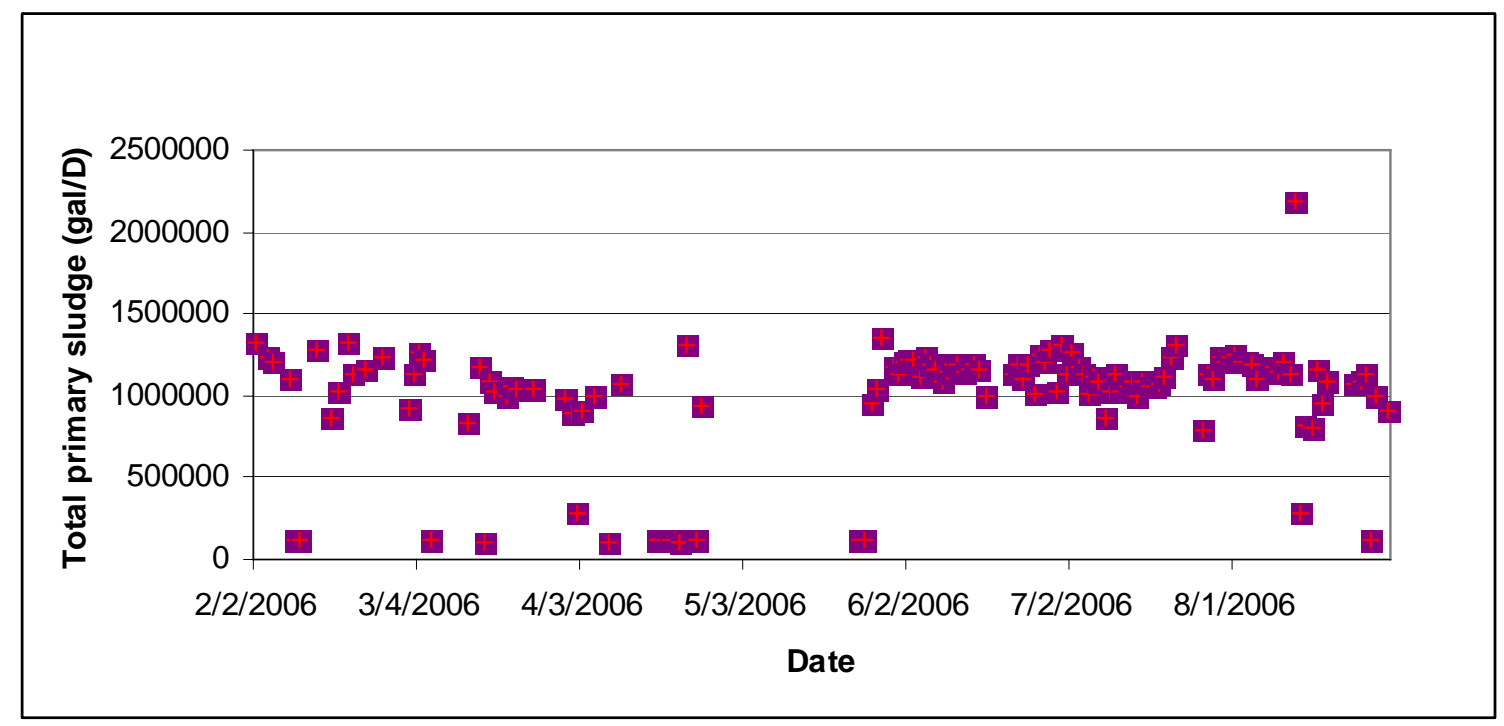

Figure 3-13: Total Primary Sludge (TPS) at Blend Tank 


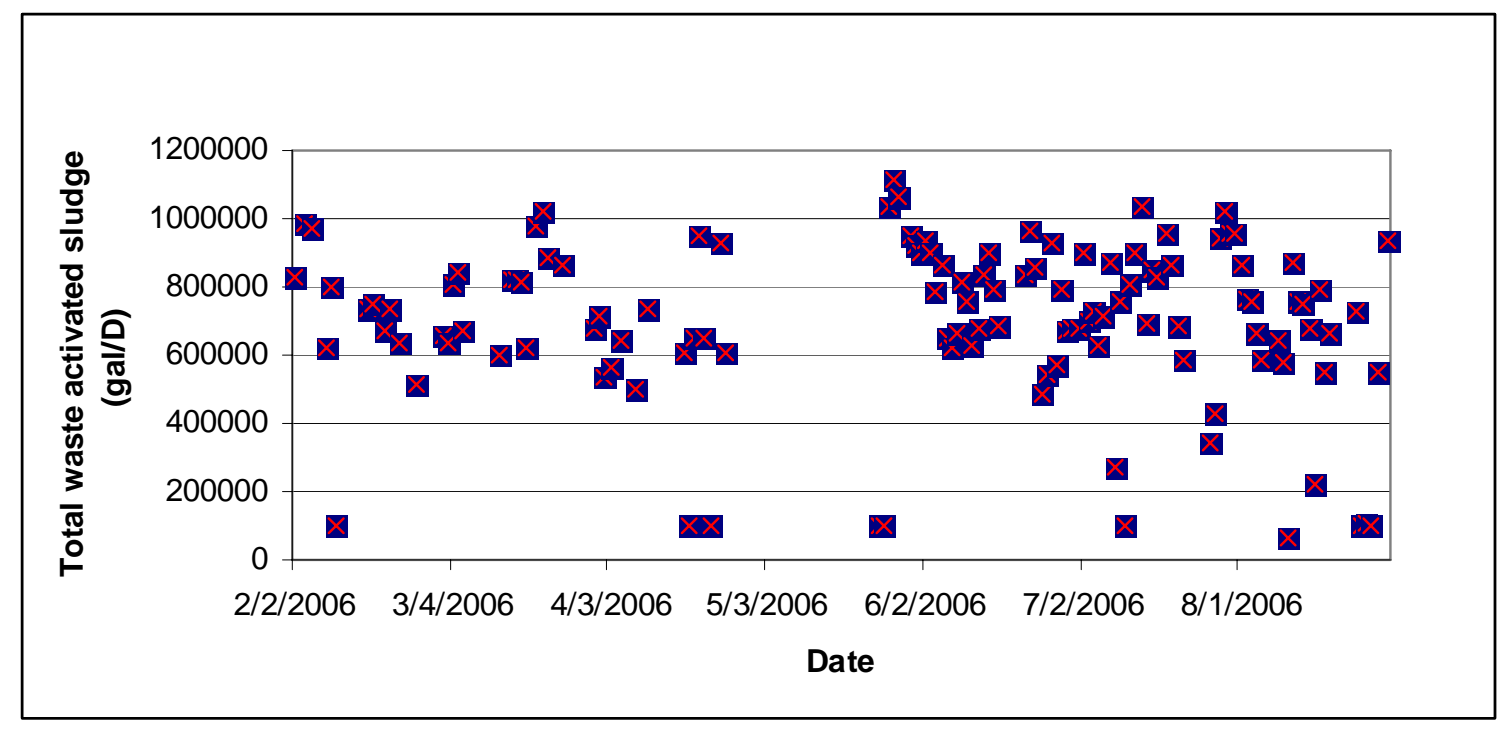

Figure 3-14: Total Waste Activated Sludge (TWAS) at Blend Tank

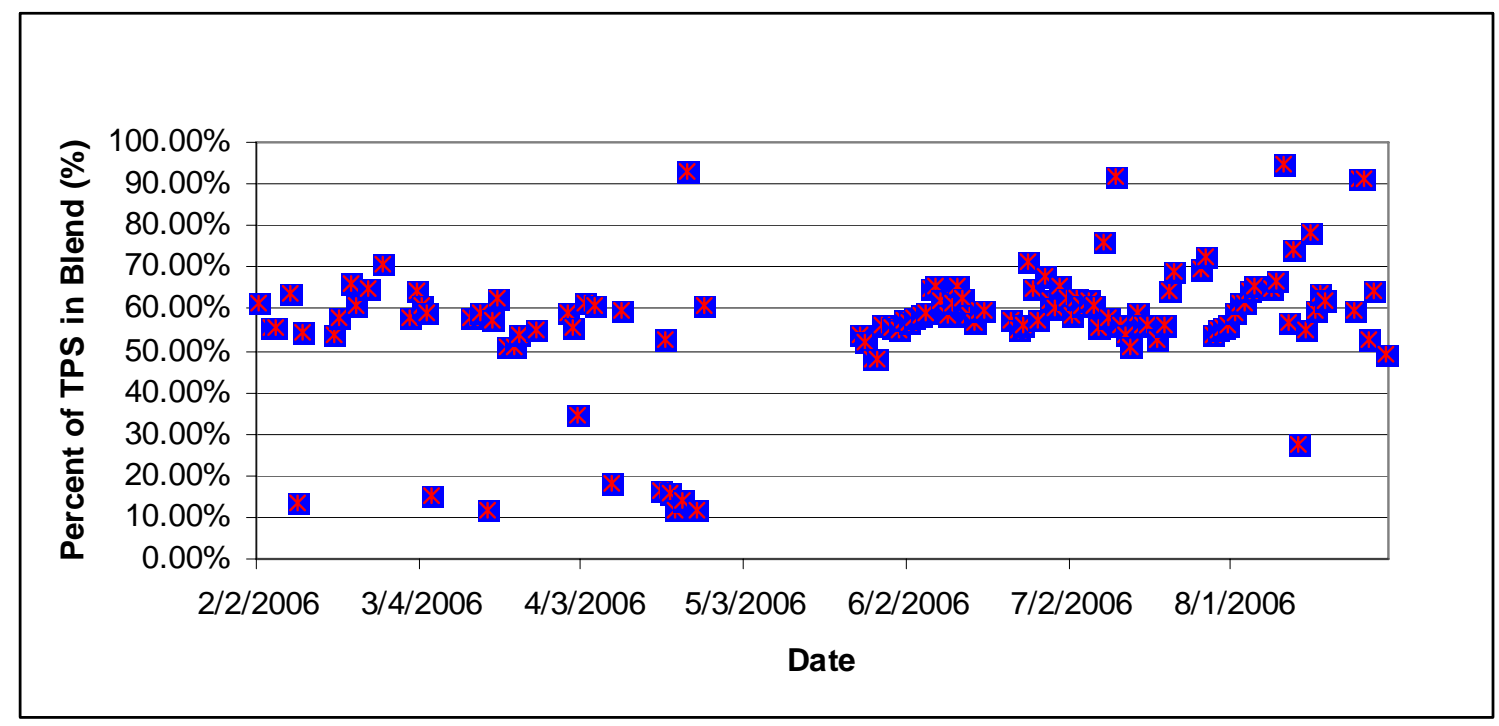

Figure 3-15: Blend Ratio Volumetric (Percent of TPS in Blend Tank) 


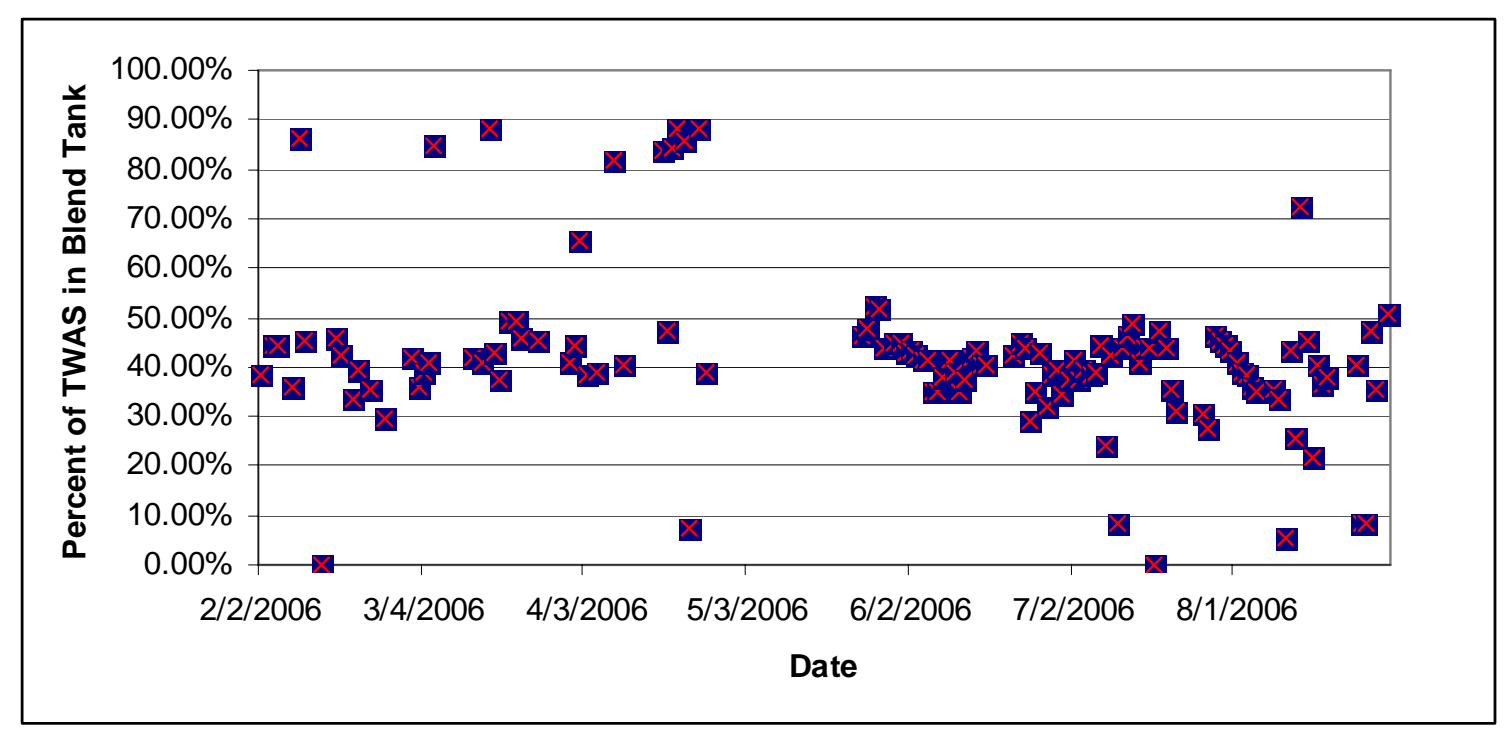

Figure 3.16: Blend Ration Volumetric (Percent of TWAS in blend tank)

\subsubsection{Percent Solids of Gravity Thickening (GT) in Blend}

As discussed earlier percent solids of gravity thickening (GT) is the percent dry ton solids of GT in the total thickening sludge of the blend tank. DCWASA calculates this variable by finding the percent solids in TPS each day and then the percent solids is multiplied by the flow of TPS to give the dry ton of solids. Percent solids of DAF in the blend tank can be calculated in the same fashion. Therefore, the summation of dry ton solids GT and dry ton solids of DAF is the total dry weight of thickening sludge in the blends tank, and the ratio of dry ton of GT and the total thickening sludge is the percent solids of GT in the blend which is shown in Figure 3-17. The percent solids of DAF is shown in Figure 3-18. 


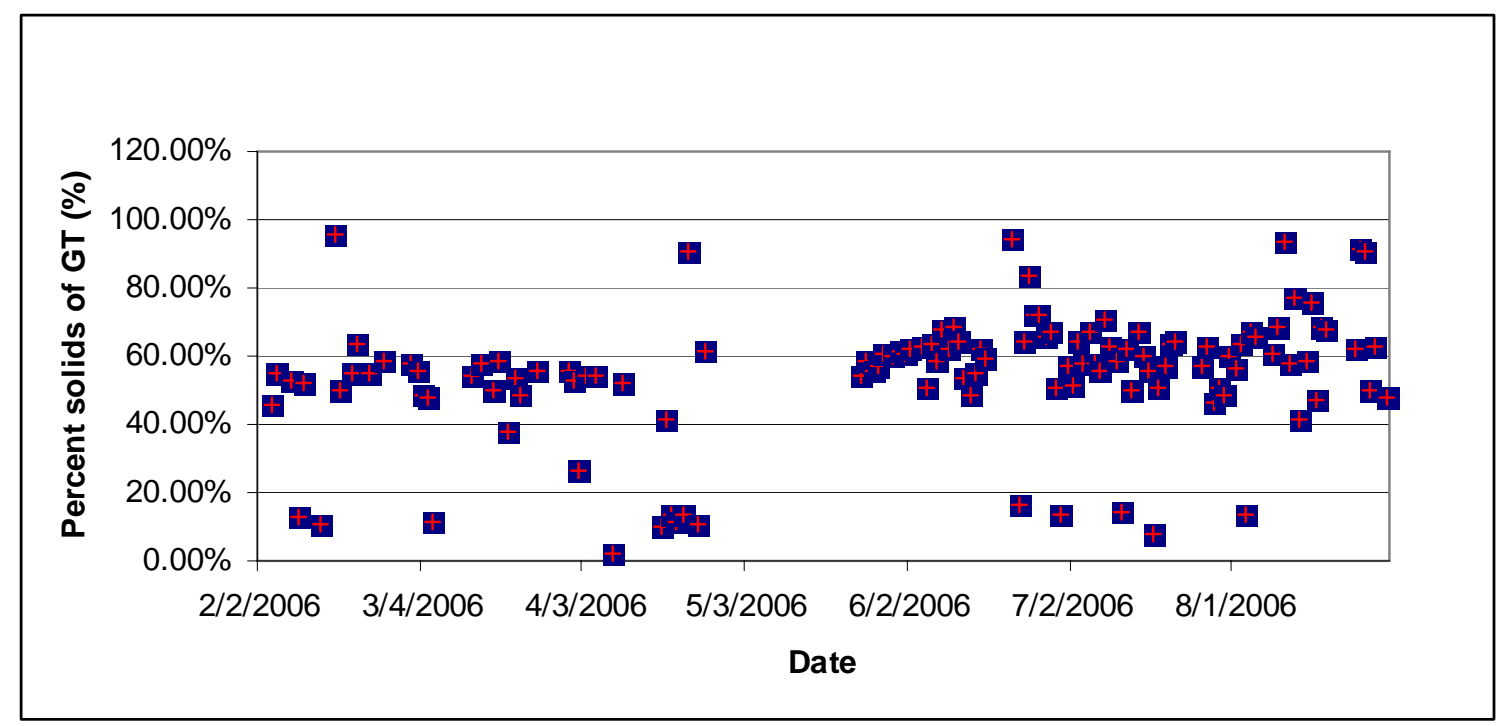

Figure 3-17: Percent solids of Gravity Thickening (GT) in Blend

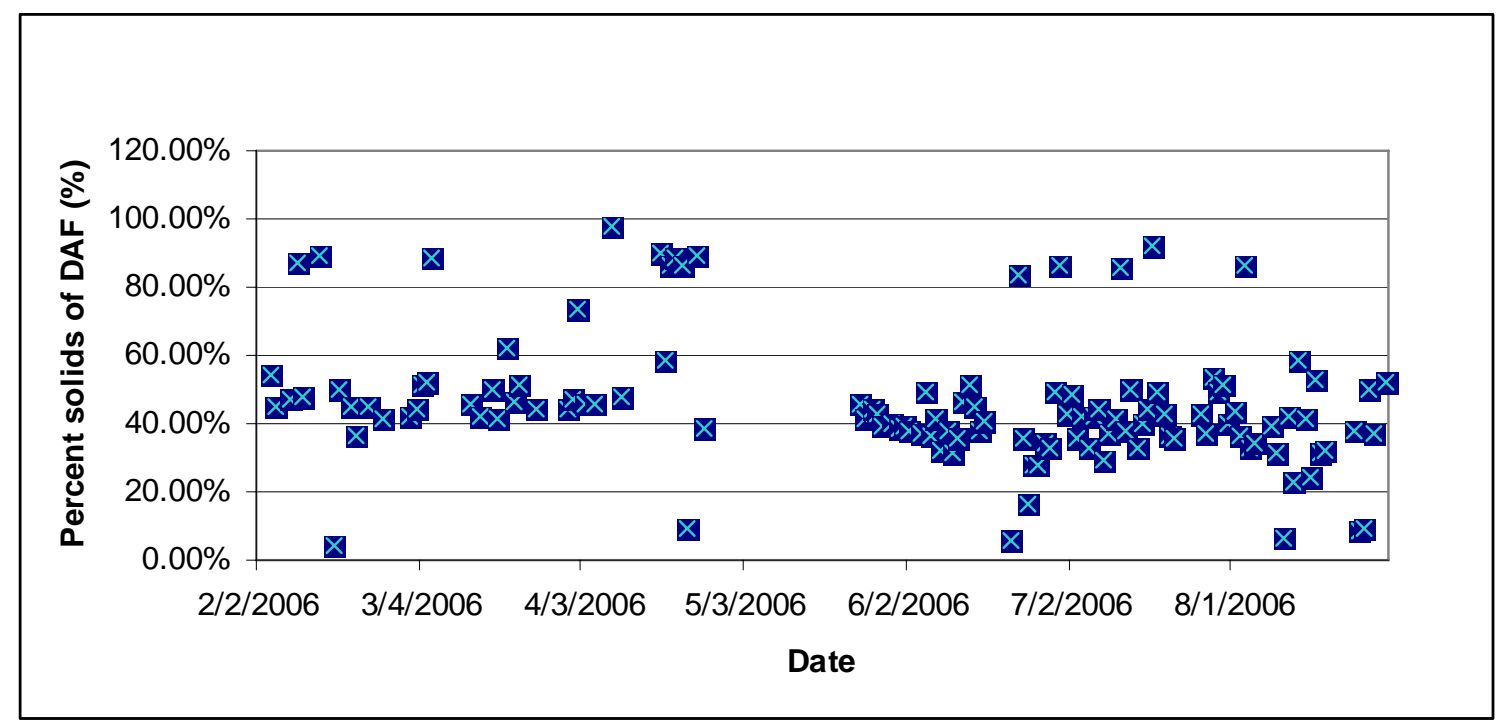

Figure 3-18: Percent solids of Dissolved Air Flotation (DAF) in Blend 


\subsection{Real-Time Odor Monitoring}

This research focuses on total volatile reduced sulfur compounds. The device used to monitor odor data at before lime addition is the OdaLog $(0-50 \mathrm{ppm})$ made by the Detection Instrument Company. For confirmation the OdaLog Low Range (0-2 ppm) device was also used to measure odor along side by side the OdaLog (0-50 ppm) at the same location and on the same gas sample. Both devices are portable gas data-logger, and primarily designed to log gas levels over extended periods of time. Due to the nature of the environments in which the instrument is likely to operate, they have been designed to be splash resistant and robust with double O-ring seals in a durable, corrosion resistant body with stainless steel fittings. An Infra Red Data Communication link as well as magnetic switches enables the OdaLog to be downloaded, calibrated, and configured without having to open the case. The OdaLog Logger uses a sensor called electrochemical sensor constructed to measure $\mathrm{H}_{2} \mathrm{~S}$ operates by supporting a reaction between the $\mathrm{H}_{2} \mathrm{~S}$ gas, the sensor electrodes, and the electrolyte. This reaction essentially consumes the $\mathrm{H}_{2} \mathrm{~S}$ gas generating an electric current in the process. The ability to accurately measure levels of total reduced sulfur is an important component in odor. When measuring total reduced sulfur odor, typical environmental conditions include high humidity (approaching 100\% RH), continuous high concentrations of $\mathrm{H}_{2} \mathrm{~S}$, and varying temperature and humidity (Gonano 2002). These factors affect the accuracy and life expectancy of the measurement instrument. However the OdaLog instruments perform better than most. The OdaLog Low Range (0-2 ppm) can monitor total reduced sulfur from $10 \mathrm{ppb}$ to $2 \mathrm{ppm}$, while OdaLog (0-50 ppm) can monitor total reduced sulfur from $100 \mathrm{ppb}$ to $50 \mathrm{ppm}$. Both devices have to be changed every 18 months. The set up of the 
monitoring system can be seen in Figure 3-19 to Figure 3-23, and the total reduced sulfur data from OdaLog Low Range and OdaLog 0-50 ppm are shown in Figure 3-24 and Figure 3-25, respectively. As the OdaLog Low Range has performance limited to 2 ppm maximum, it is used only for checking the performance of the OdaLog (0-50 ppm). This research uses data from the OdaLog (0-50 ppm) for analysis. Both devices measure every 30 minutes, and all data come from the dewatered solids conveyor train running continuously over 24 hours.

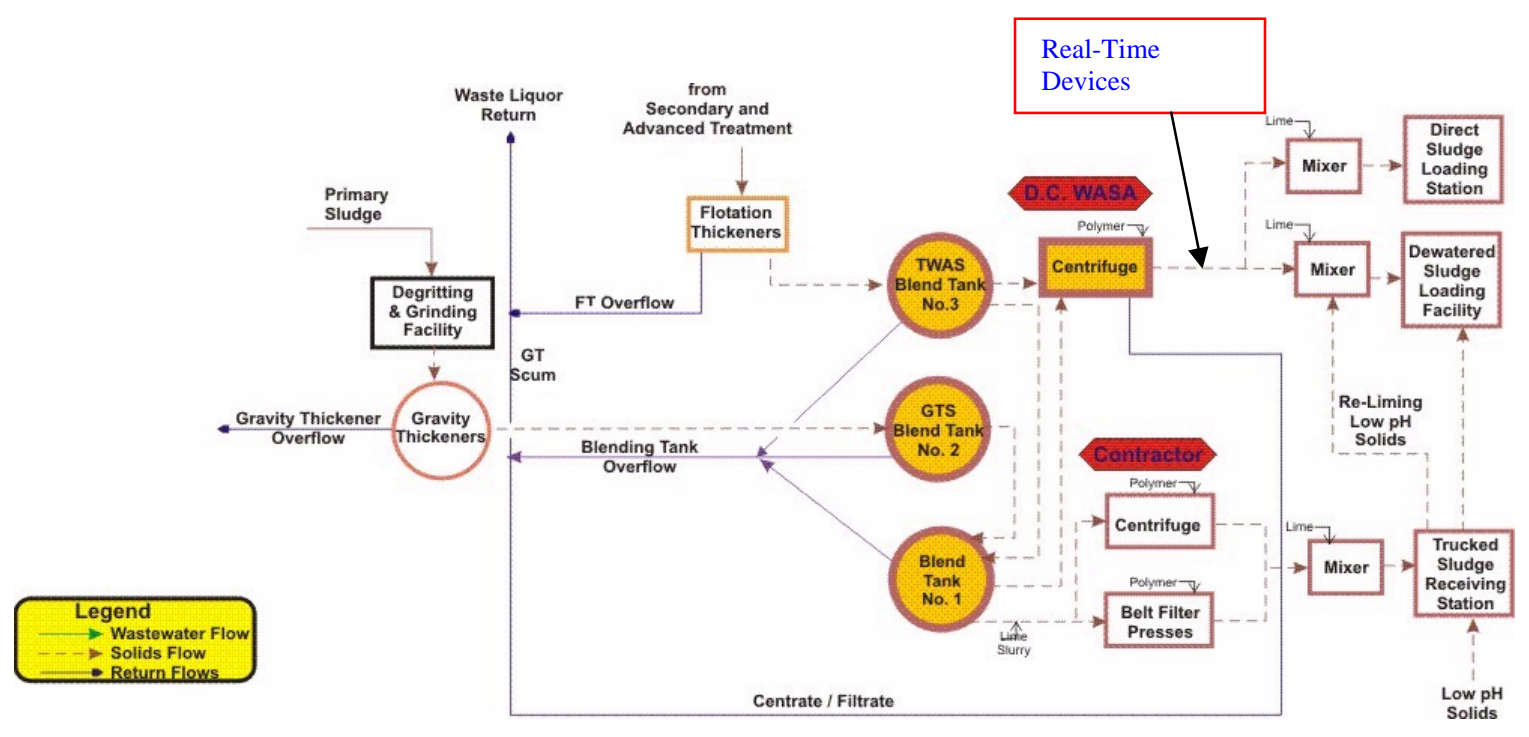

Figure 3-19: Location of Real-Time Monitored Devices 


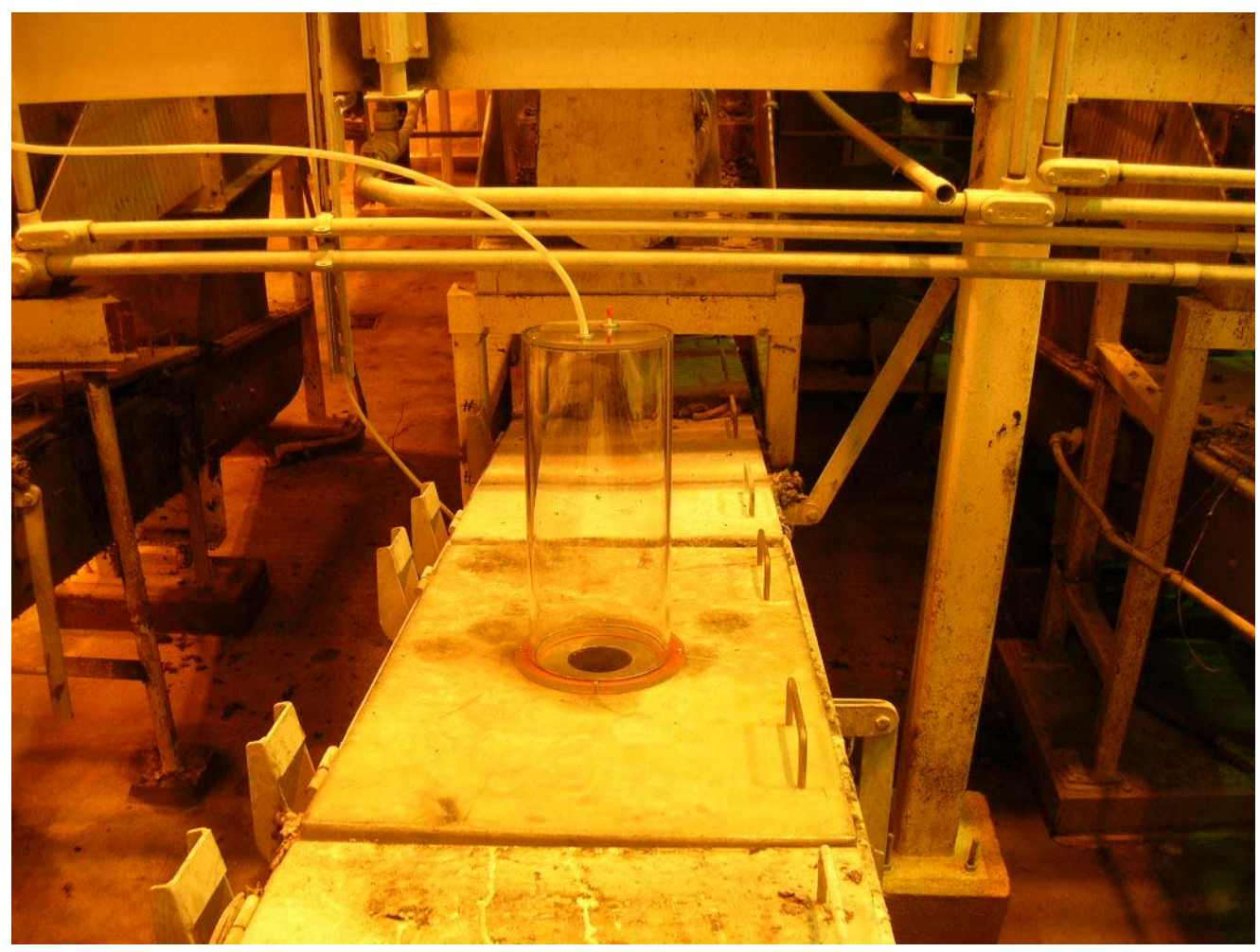

Figure 3-20: Location to Monitor Total Reduce Sulfur

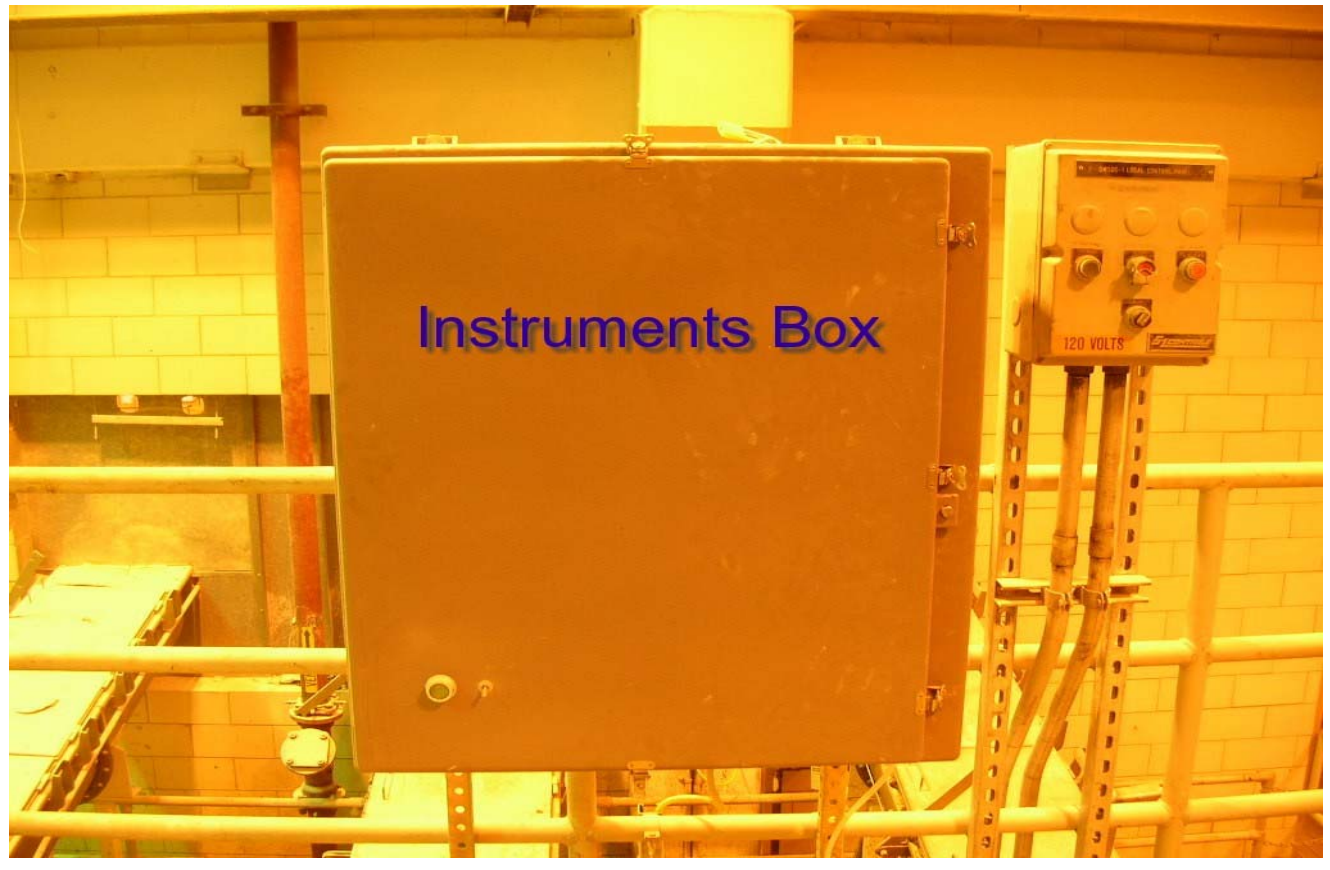

Figure 3-21: The container of both devices 


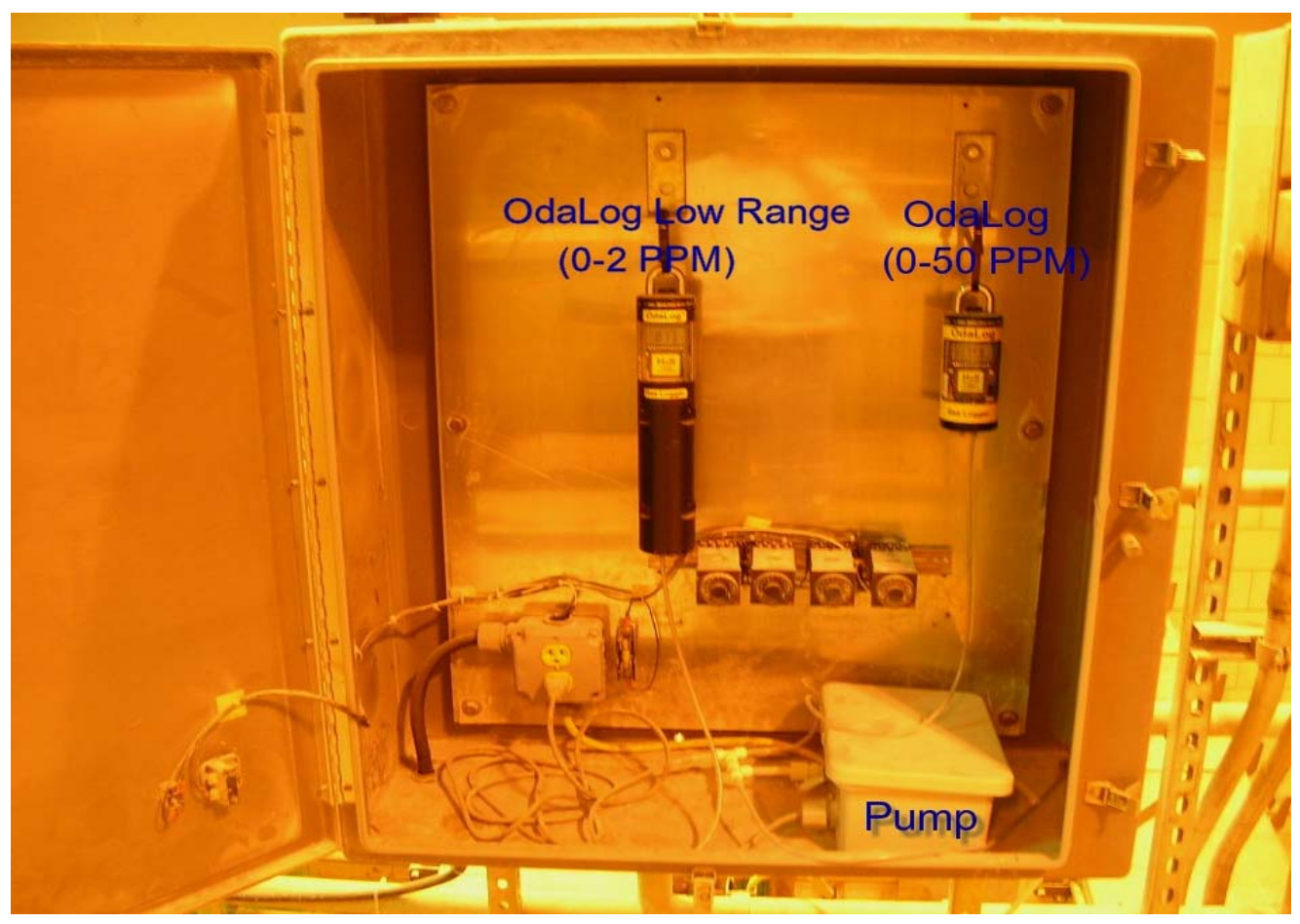

Figure 3-22: OdaLog Low Range and OdaLog (0-50 PPM)

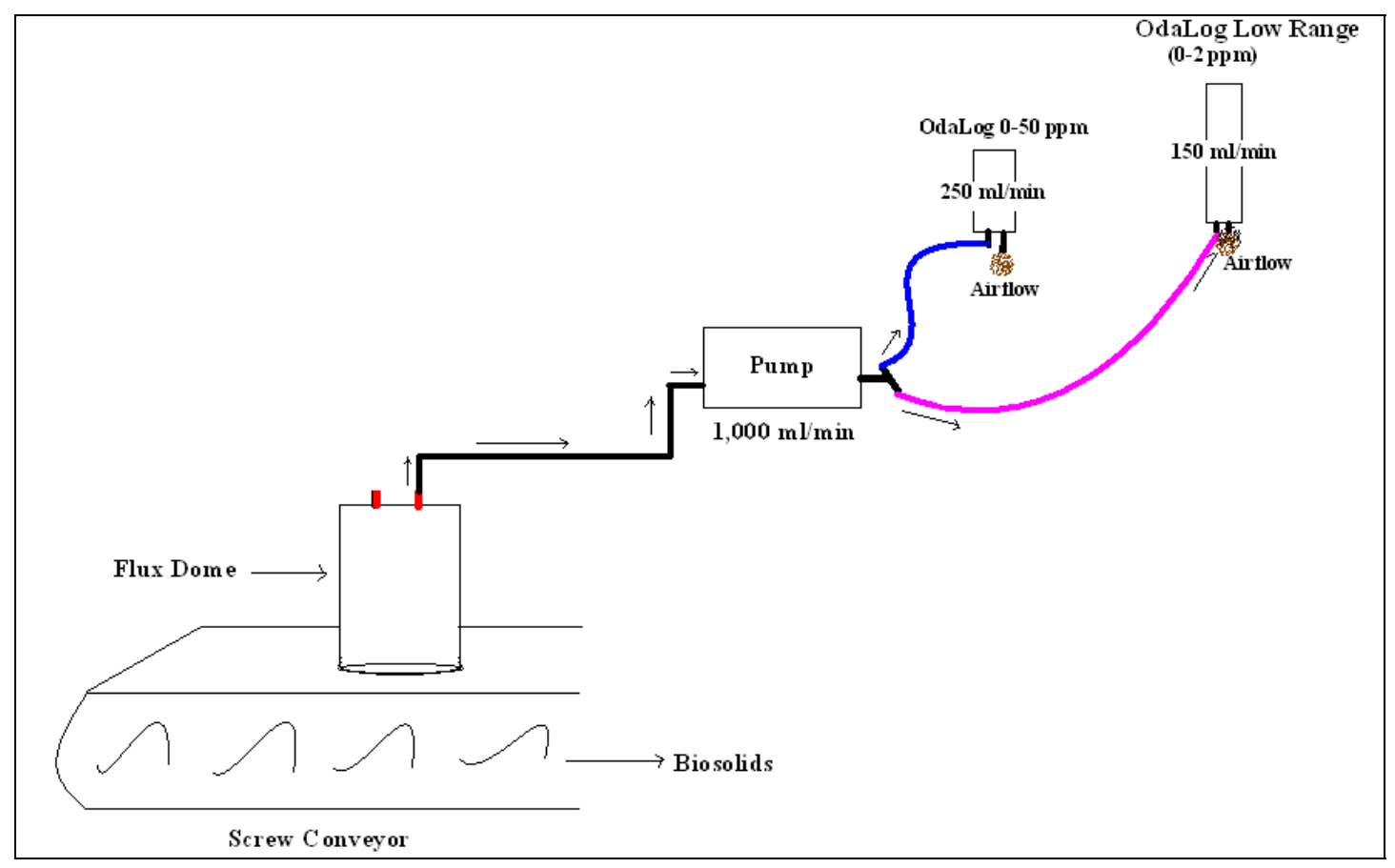

Figure 3-23: Air Flow Diagram 
Figure 3-19 to Figure 3-22 show the location of the instrument installation on the process train, called the Mixed Input Conveyors (MIC). On the lid of the train or screw conveyor is a dome which draws gas from the train through a pump to OdaLog Low Range (0-2 ppm) and OdaLog 0-50 devices which are installed in the box on the upper level (Figure 3-21). Figure 3-22 shows devices inside the container, including the pump, OdaLog Low Range, and OdaLog 0-50. Figure 3-23 shows air flow from conveyor through both devices.

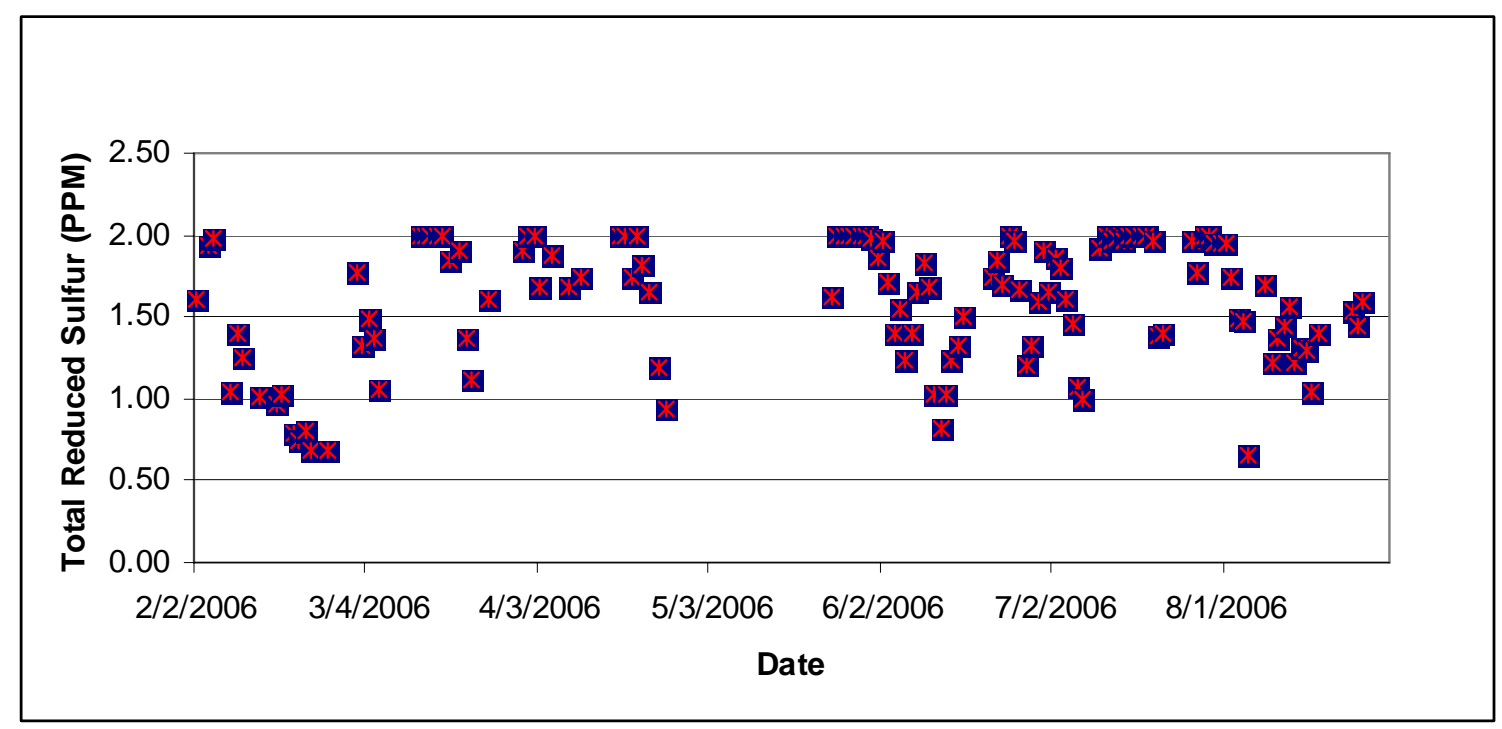

Figure 3-24: Total Reduced Sulfur from OdaLog Low Range (0-2 ppm) 


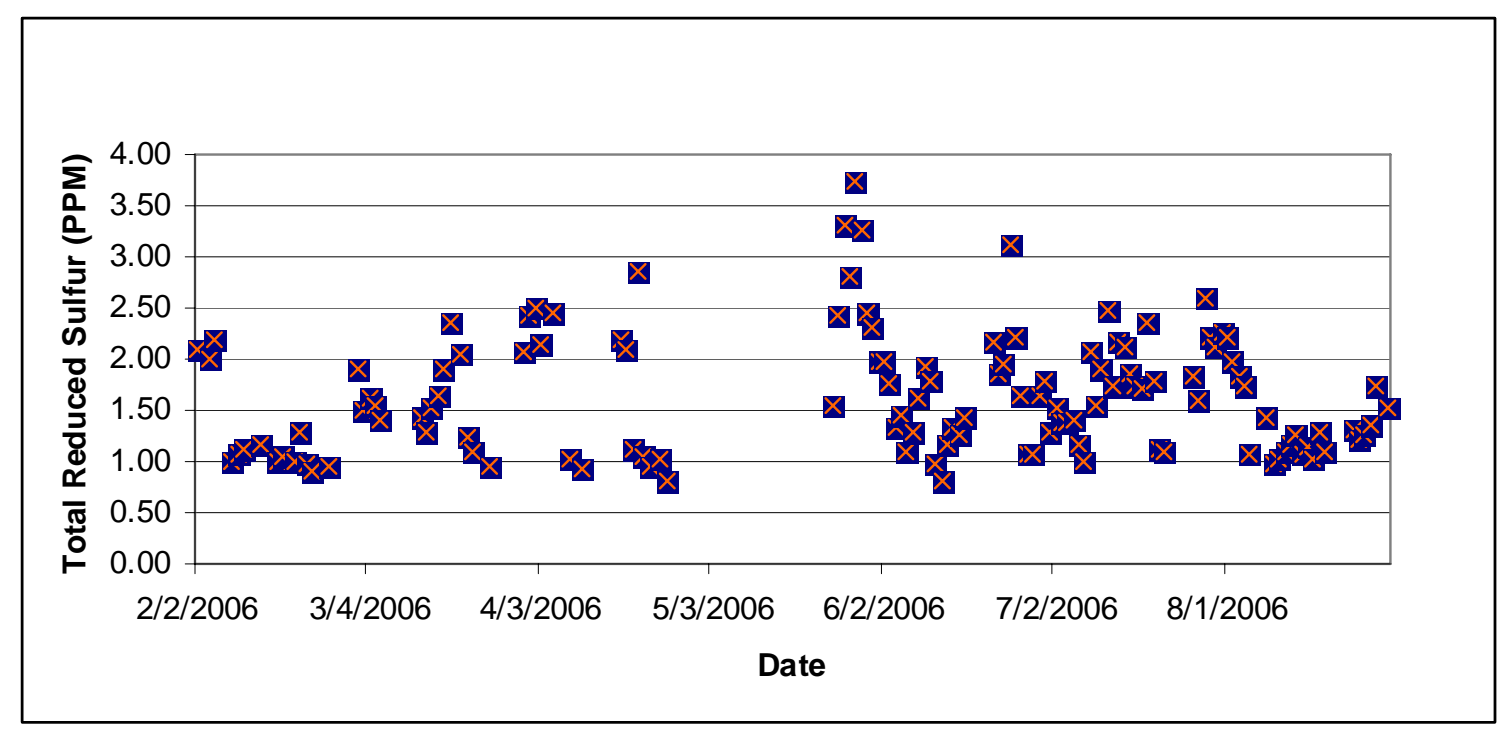

Figure 3-25: Total Reduced Sulfur Data from OdaLog 0-50 ppm

Figure 3-24 and Figure 3-25 show daily the averages. During 02/01/06 to 04/25/06, both devices had calibration problem although they read data with the same general trend. At that point both devices were sent to the manufacturer to be calibrated side by side. After that the data are close together, as seen after 05/24/06. For this reason, the research divides data into three groups: February to August, February to April, and May to August. 


\section{Chapter 4: Data Analysis and Results}

In this chapter, graphical analysis and the STAT tool are used to analyze process and total reduced sulfur data. In order to produce a forecasting model, it is important to find the correlation between independent variables $\mathrm{x}_{1}, \mathrm{x}_{2}, \ldots \ldots, \mathrm{x}_{\mathrm{n}}$ and the dependent variable $y$. In this research the independent variables are process variables data, and the dependent variable is total reduced sulfur data. STAT tool was used to determine the correlation between two variables and graphical analysis was used to support and evaluate the relationship of two or more variables also. Therefore, this research will use both methodologies to find correlation. Specifically, after getting the process variables having strong a correlation with total reduced sulfur, then this research uses STAT tool, multiple regression mode, to analyze and find the best regression equations and multiple regression models. In addition, this research uses dummy variables and interaction techniques to improve those models.

\subsection{Graphical analysis and Correlation Analysis}

\subsubsection{Graphical Analysis}

As this research needs more reliability to find out which process variables have a strong correlation with total reduced sulfur, it is necessary to use graphical analysis to compare with statistical applications. Graphical analysis, it is the simple way to find relationships between total reduced sulfur with each process variable by plotting two variables in the same graph. In the graph, the $\mathrm{X}$ axis is the date of monitoring, and the $\mathrm{Y}$ axis having primary axis which is total reduced sulfur and a secondary axis which is the process 
variable. The following graphs are the results of graphical analysis of the total reduced sulfur and the process variables. 


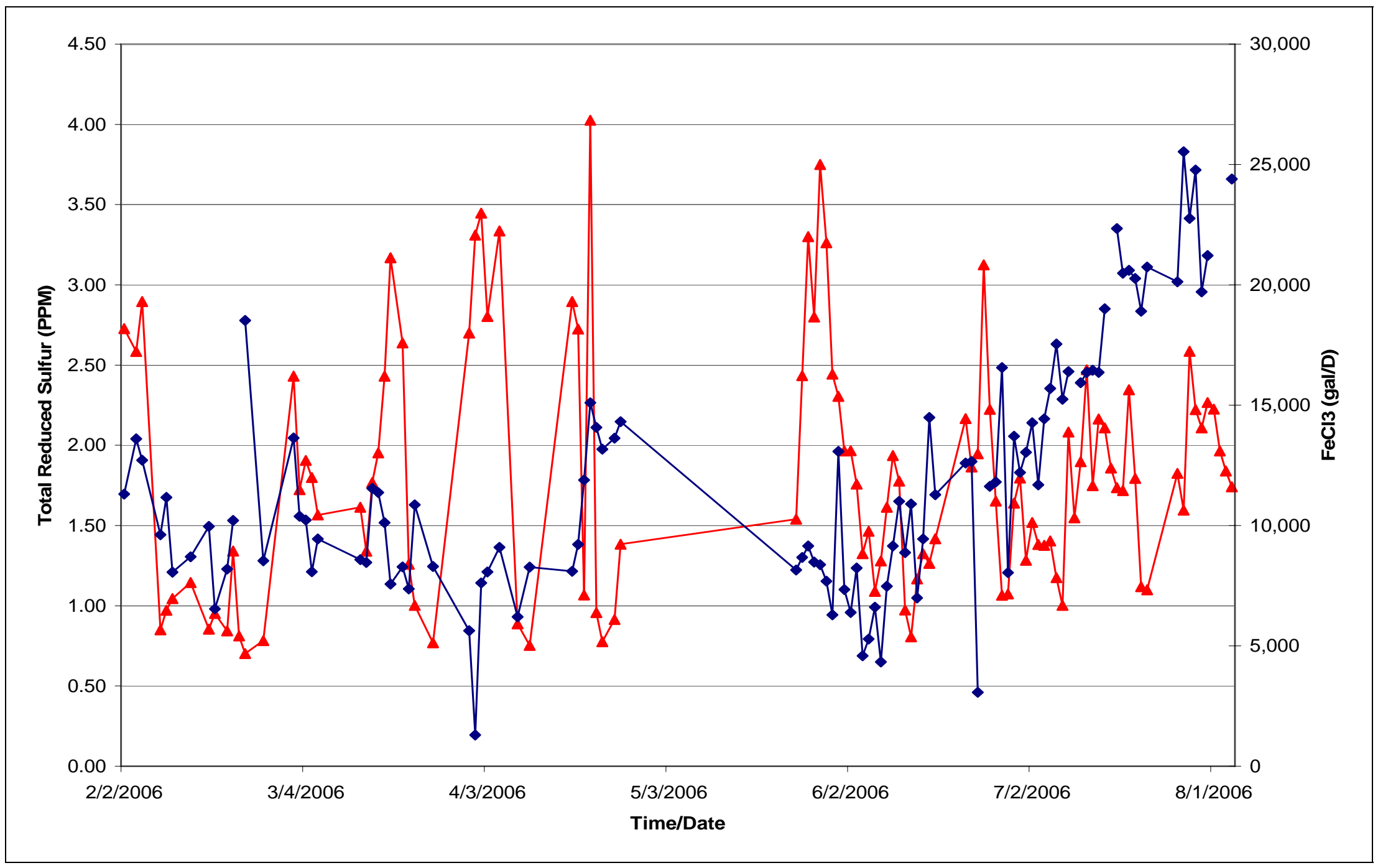

Figure 4-1: Total Reduced Sulfur VS $\mathrm{FeCl}_{3}$ 


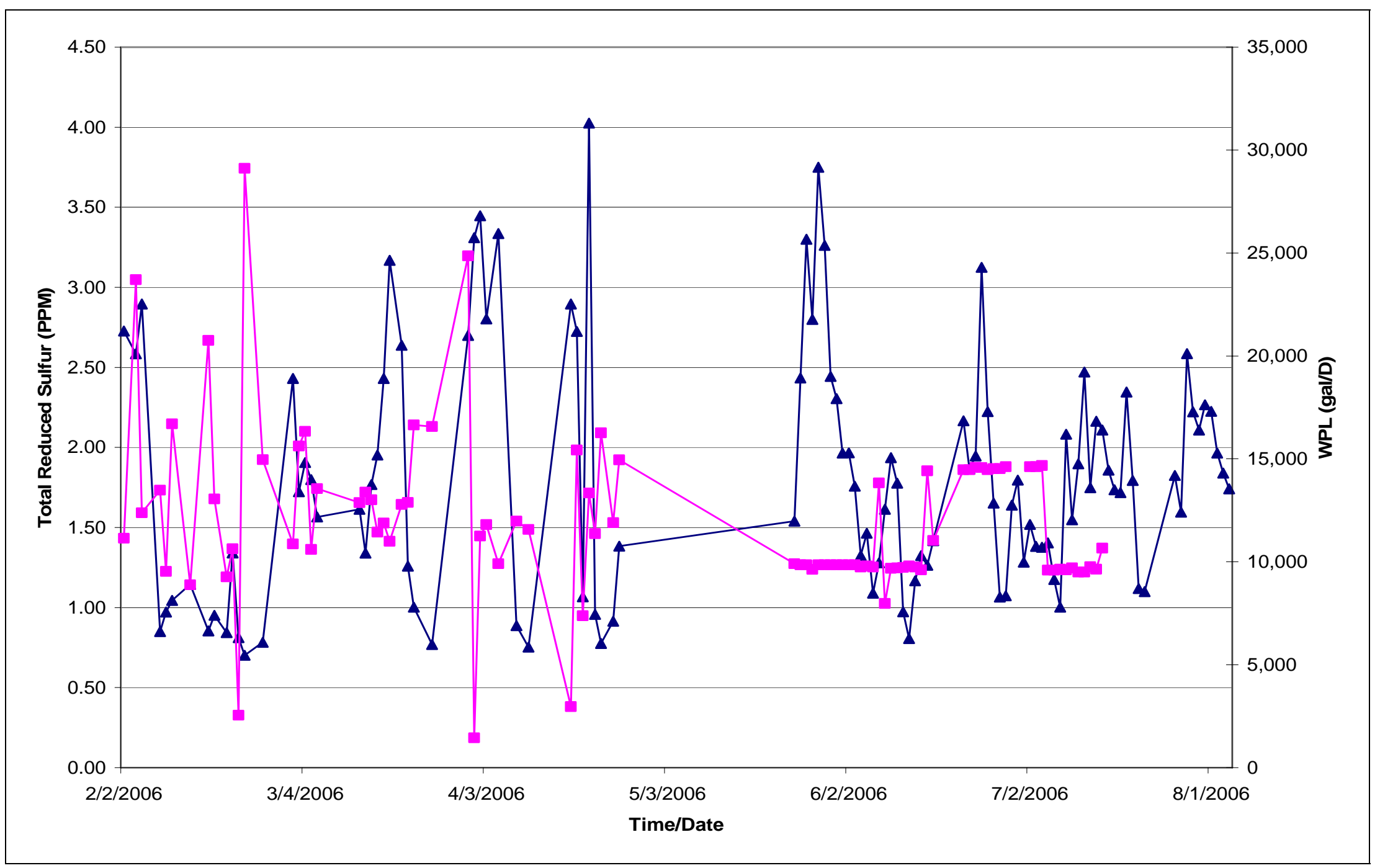

Figure 4-2: Total Reduced Sulfur VS WPL 


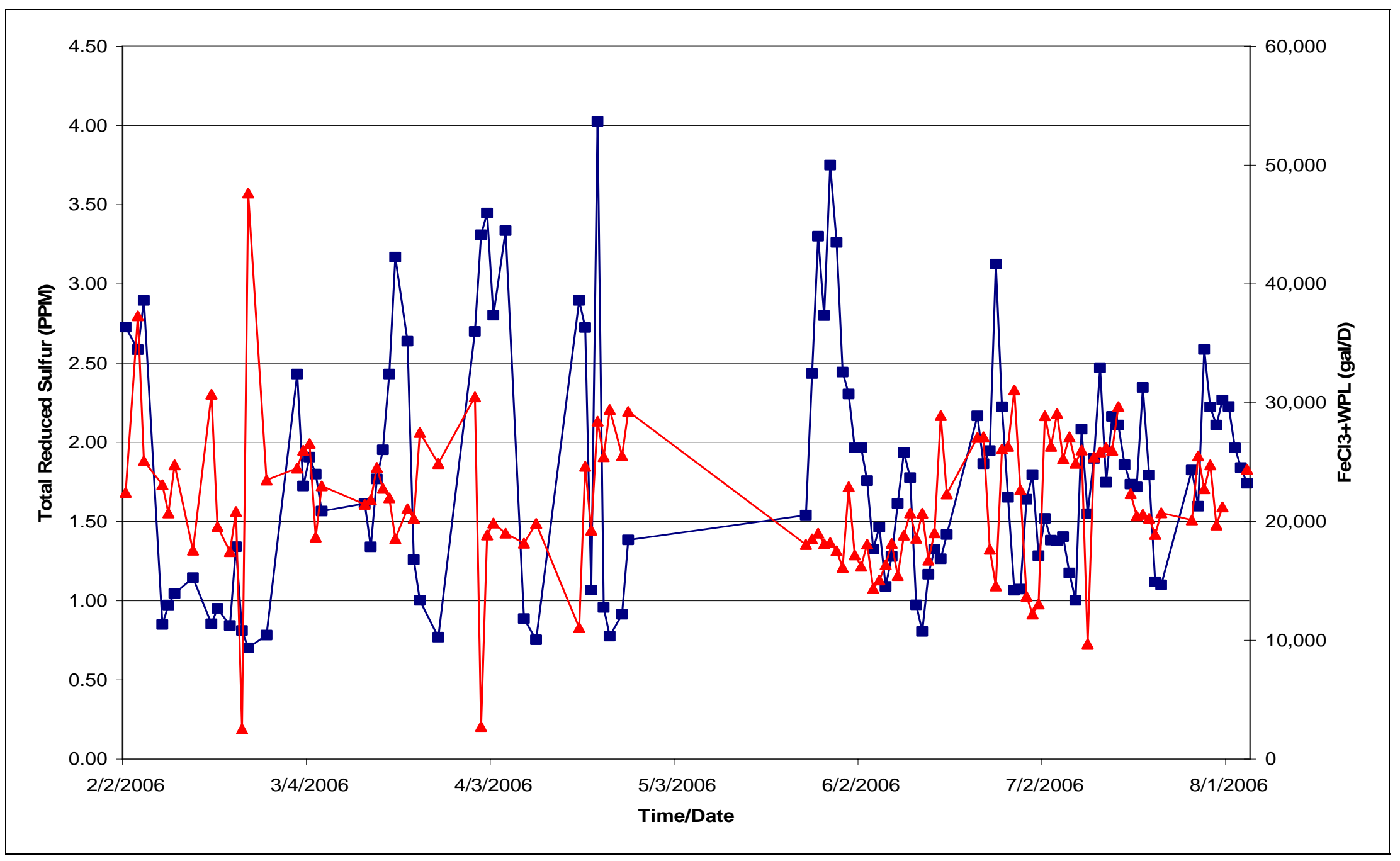

Figure 4-3: Total Reduced Sulfur VS Summation of $\mathrm{FeCl}_{3}$ and WPL 


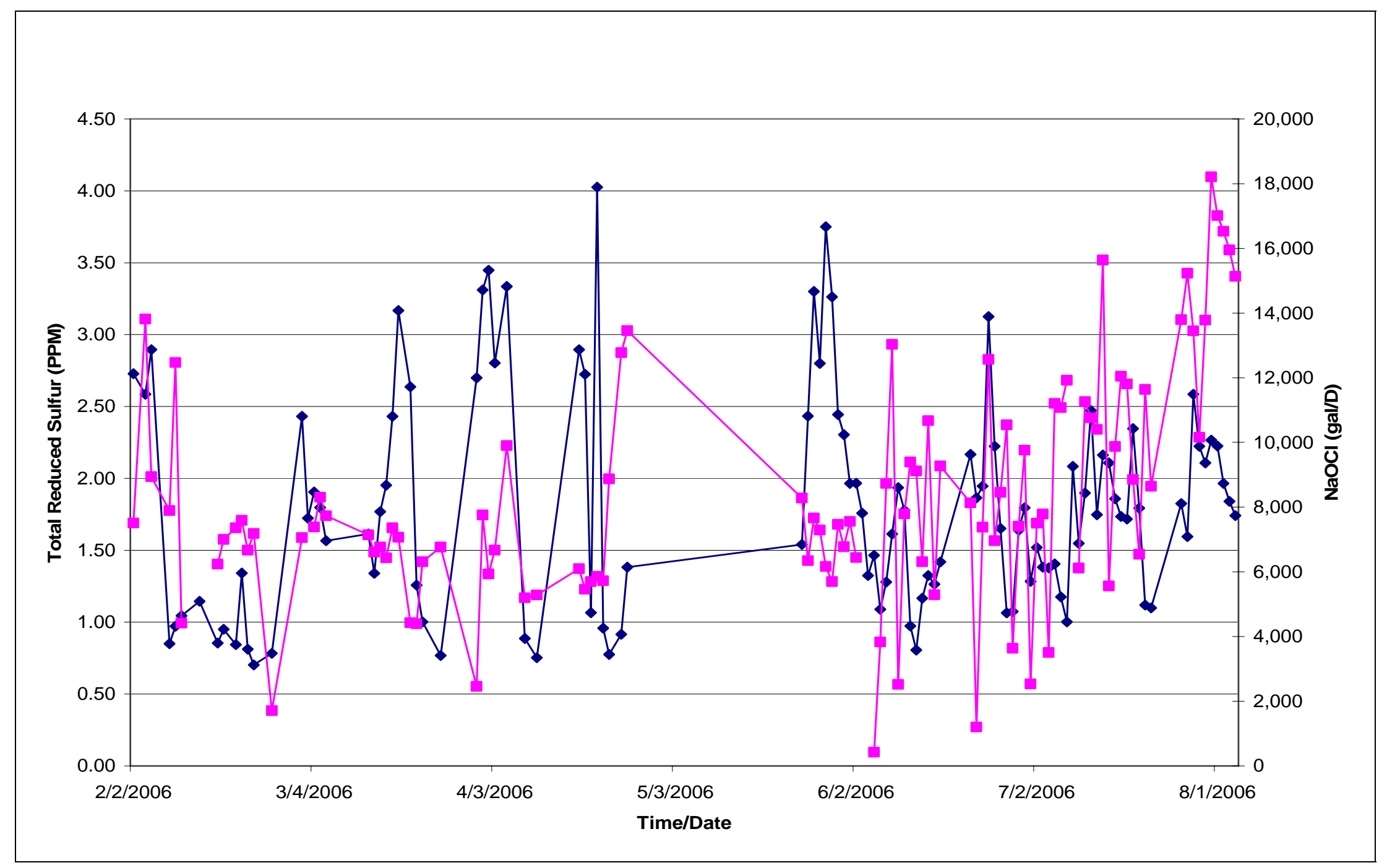

Figure 4-4: Total Reduced Sulfur VS NaOCl 


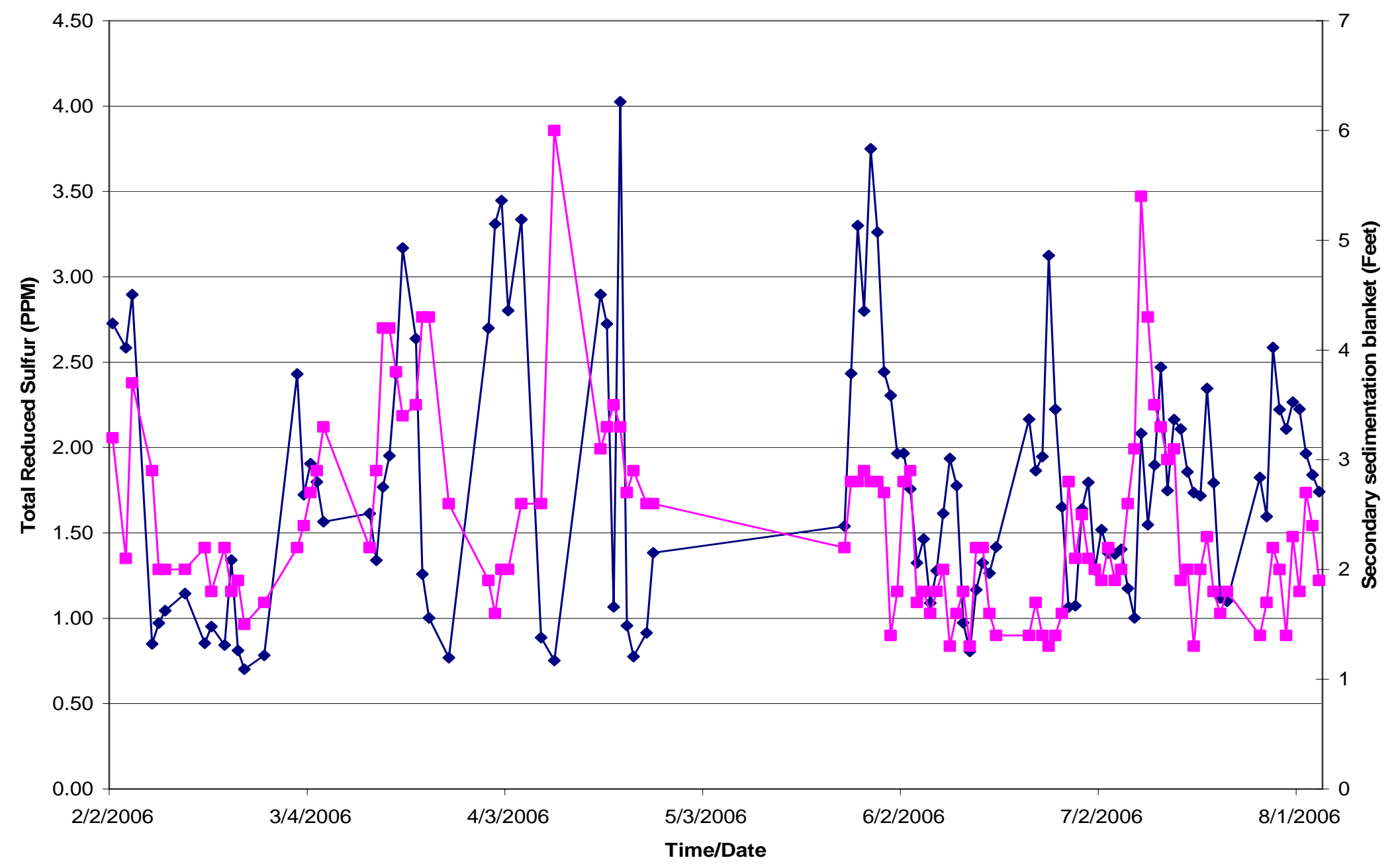

Figure 4-5: Total Reduced Sulfur VS Secondary sedimentation east blanket depth 


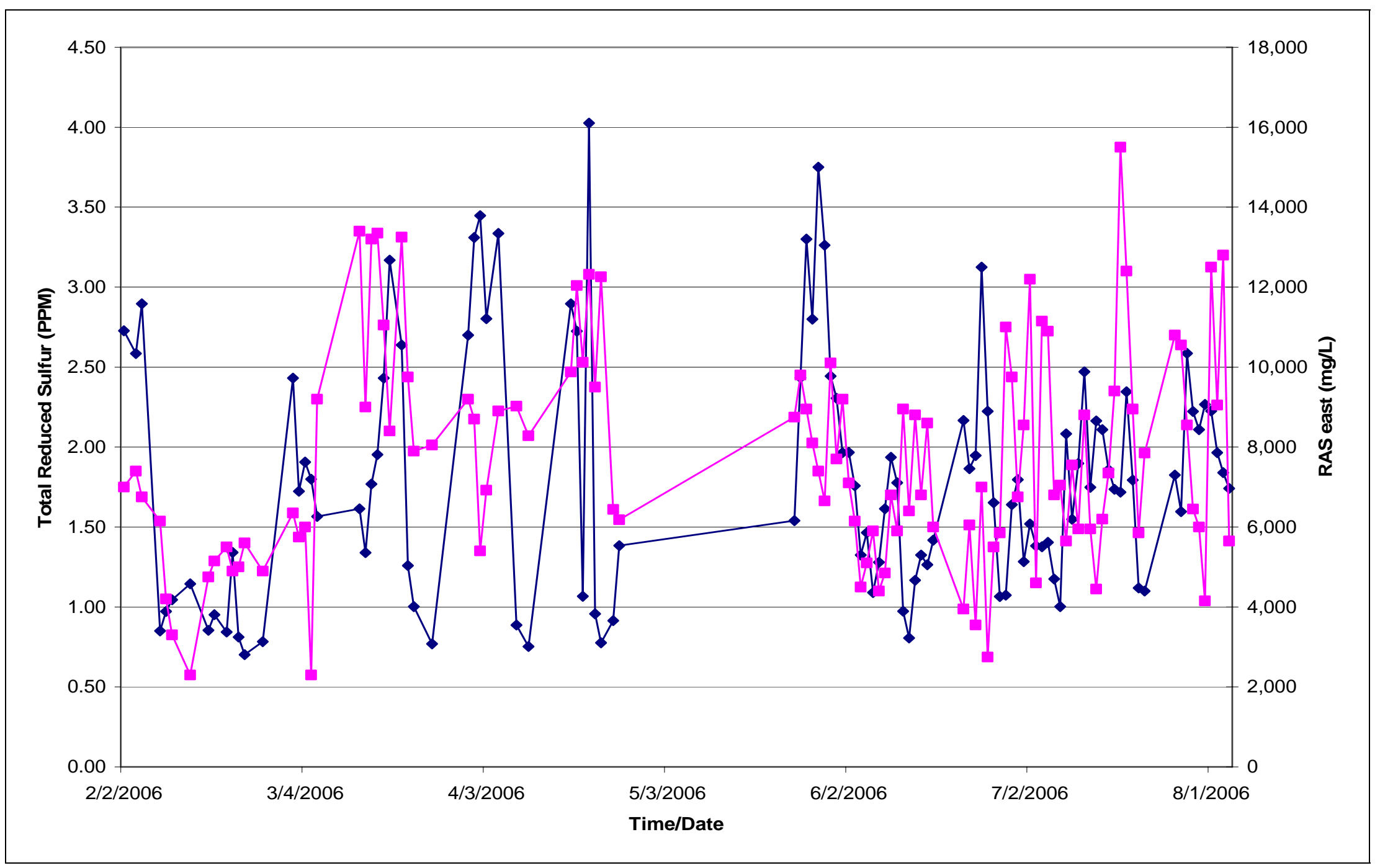

Figure 4-6: Total Reduced Sulfur VS RAS east 


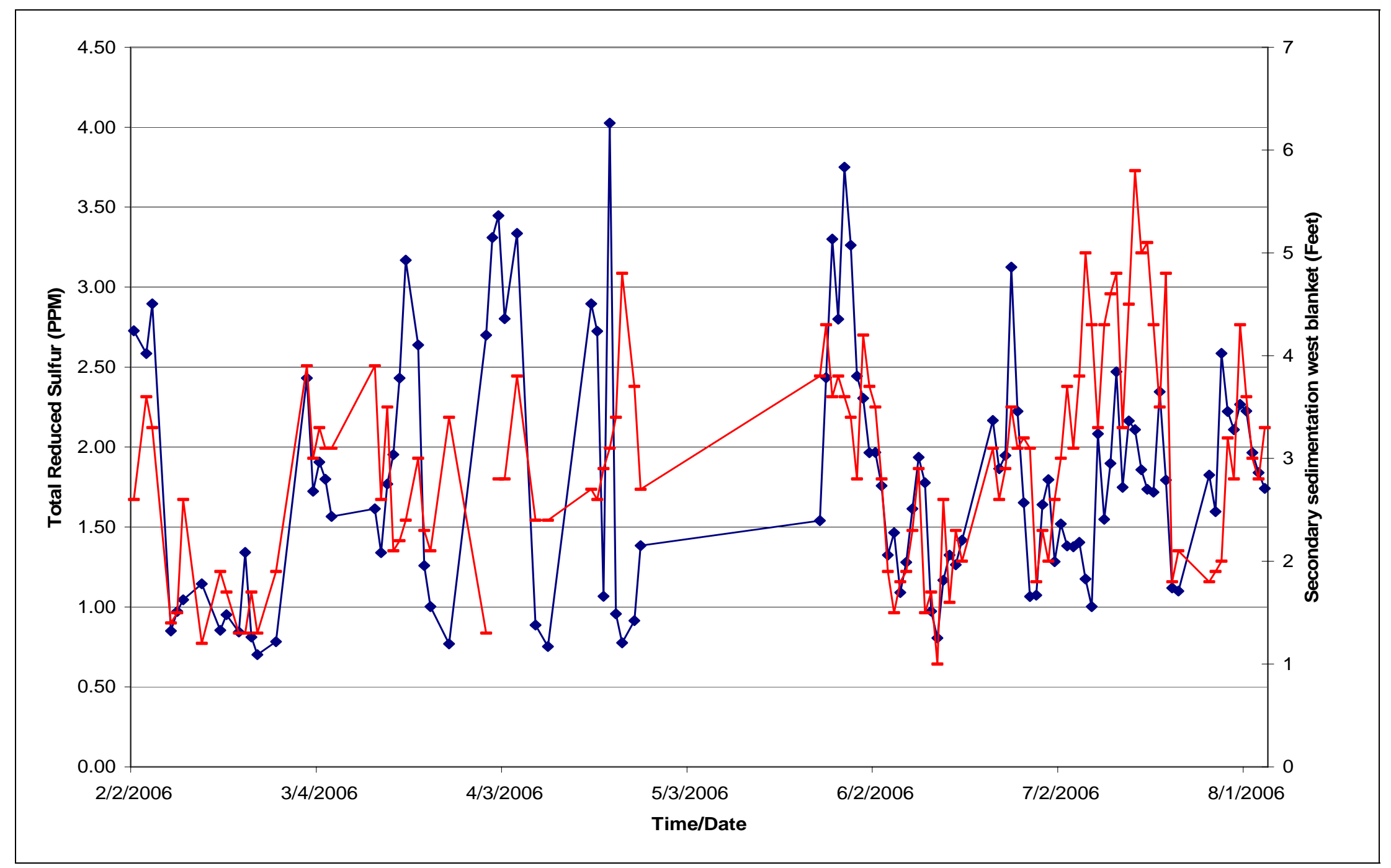

Figure 4-7: Total Reduced Sulfur VS Secondary sedimentation west blanket depth 




Figure 4-8: Total Reduced Sulfur VS RAS West 


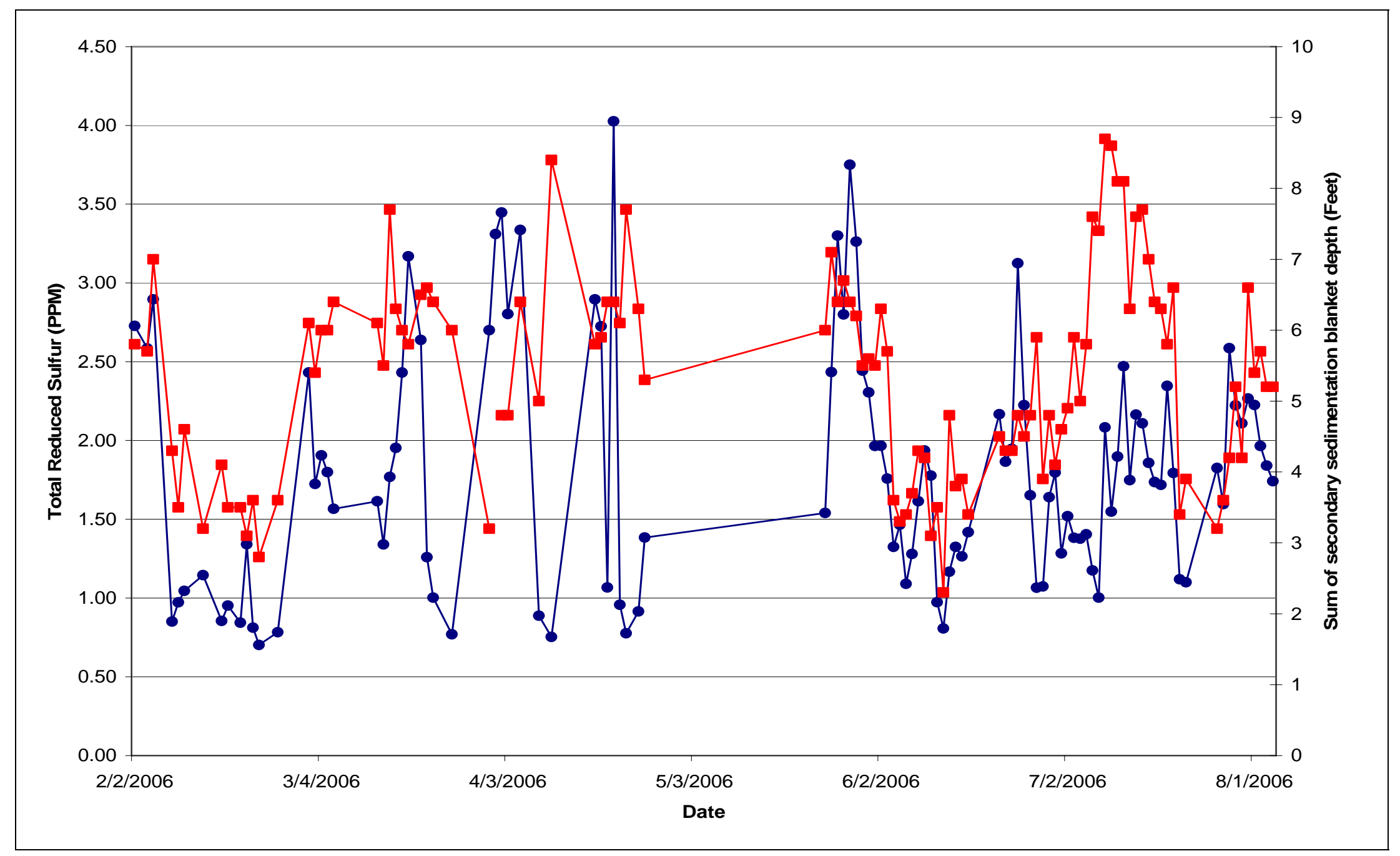

Figure 4-9: Total Reduced Sulfur VS Sum of secondary sedimentation blanket depth 


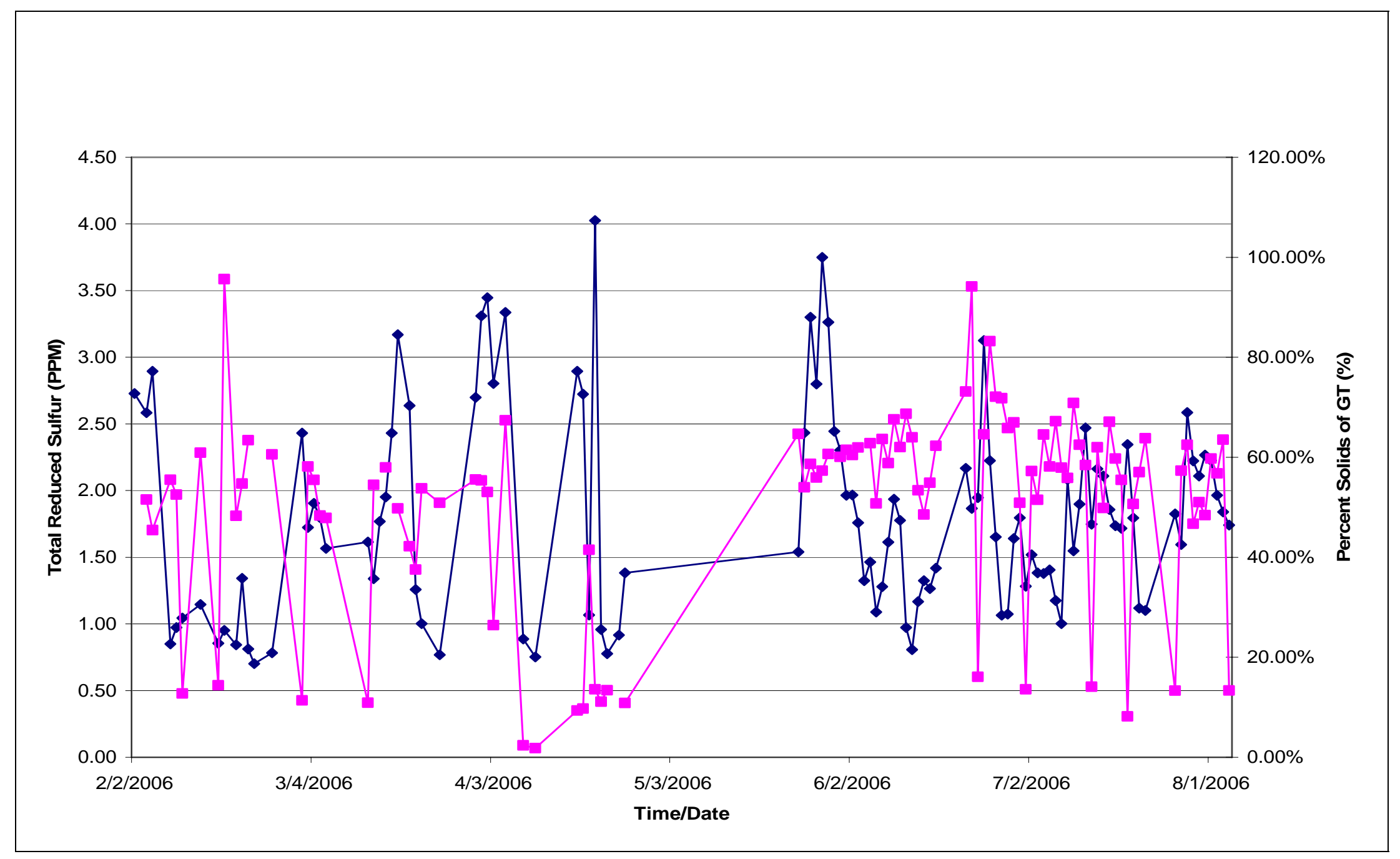

Figure 4-10: Total Reduced Sulfur VS Percent Solids of GT in Blend 


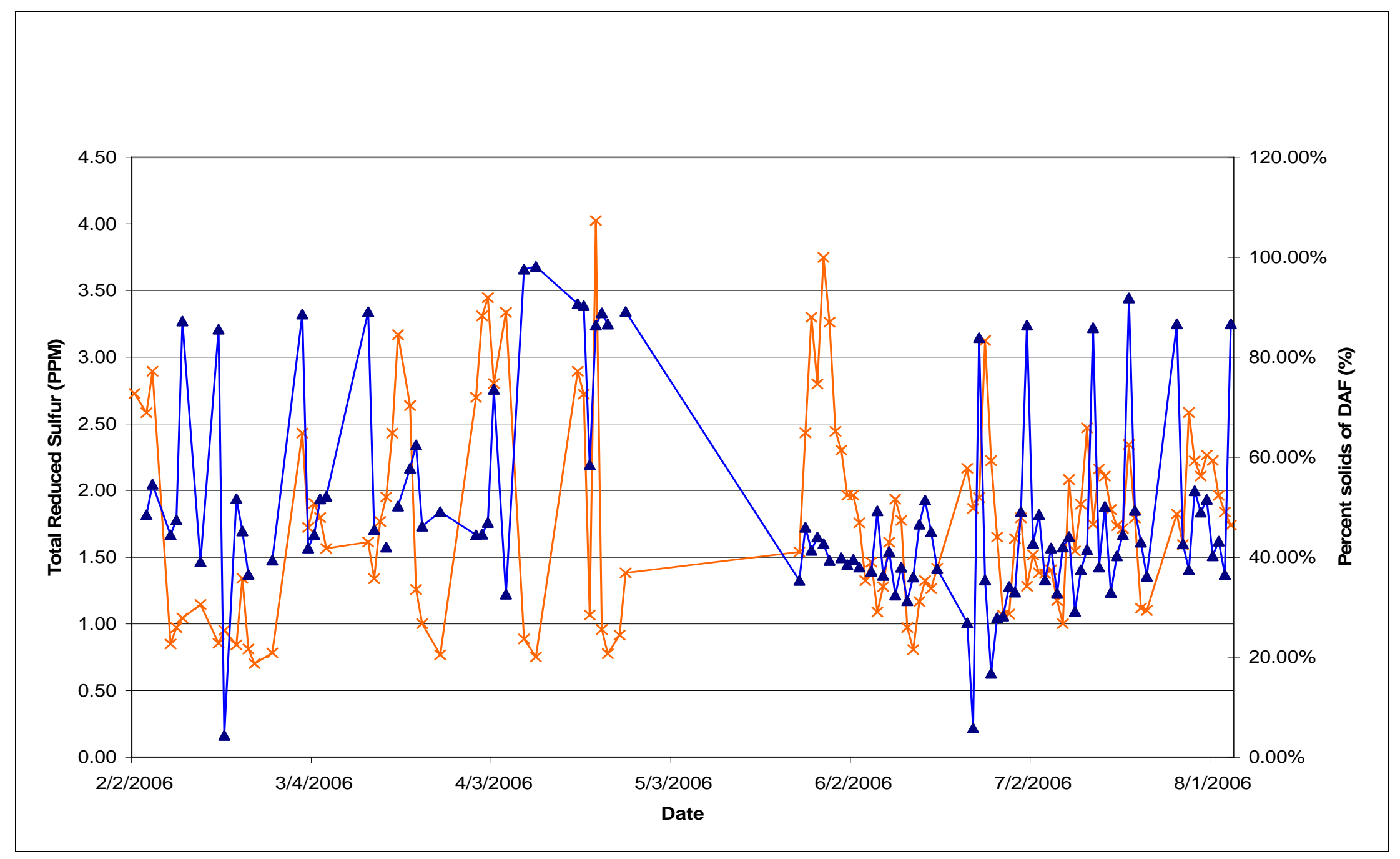

Figure 4-11: Total Reduced Sulfur VS Percent Solids of DAF in Blend 


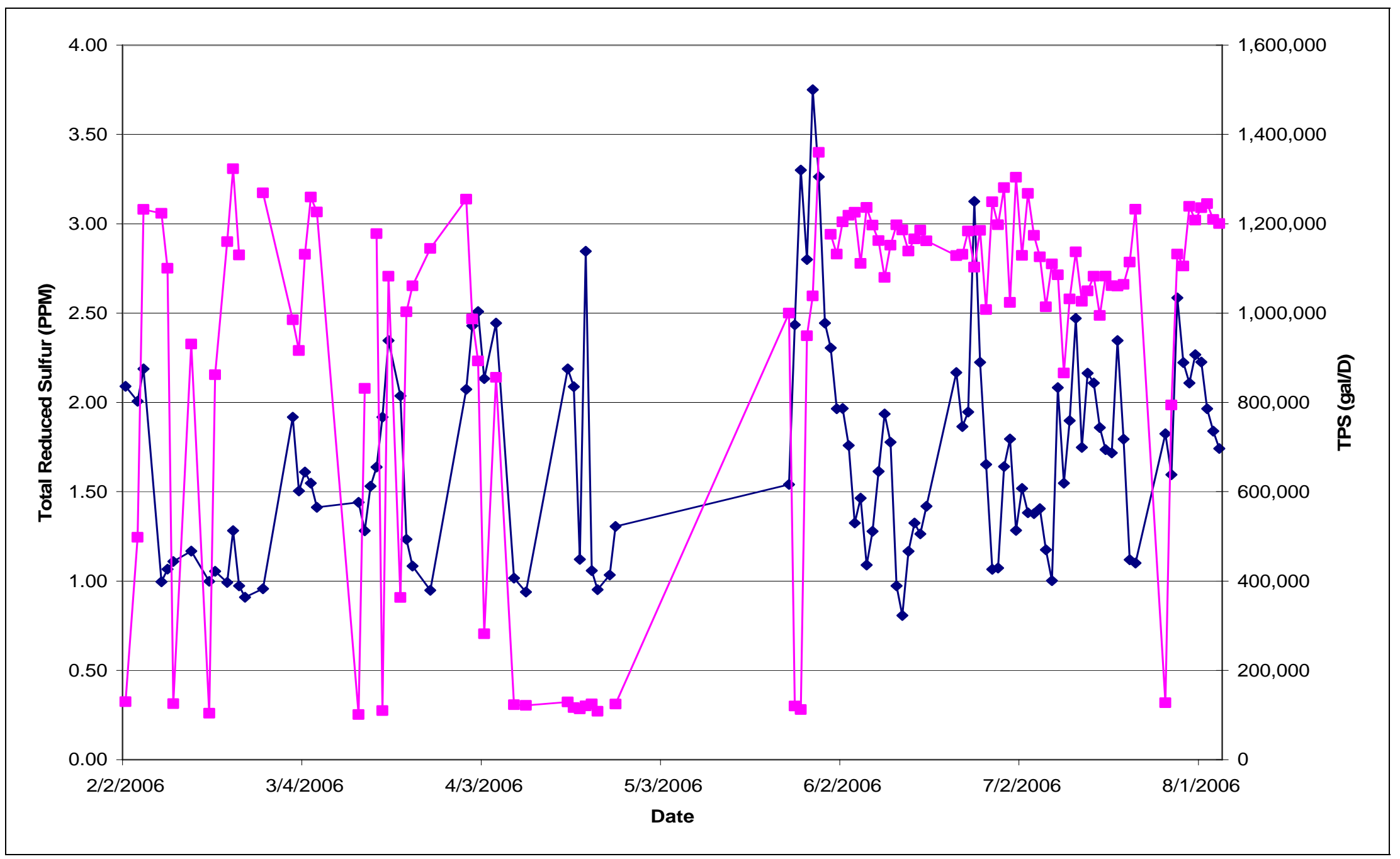

Figure 4-12: Total Reduced Sulfur VS TPS 


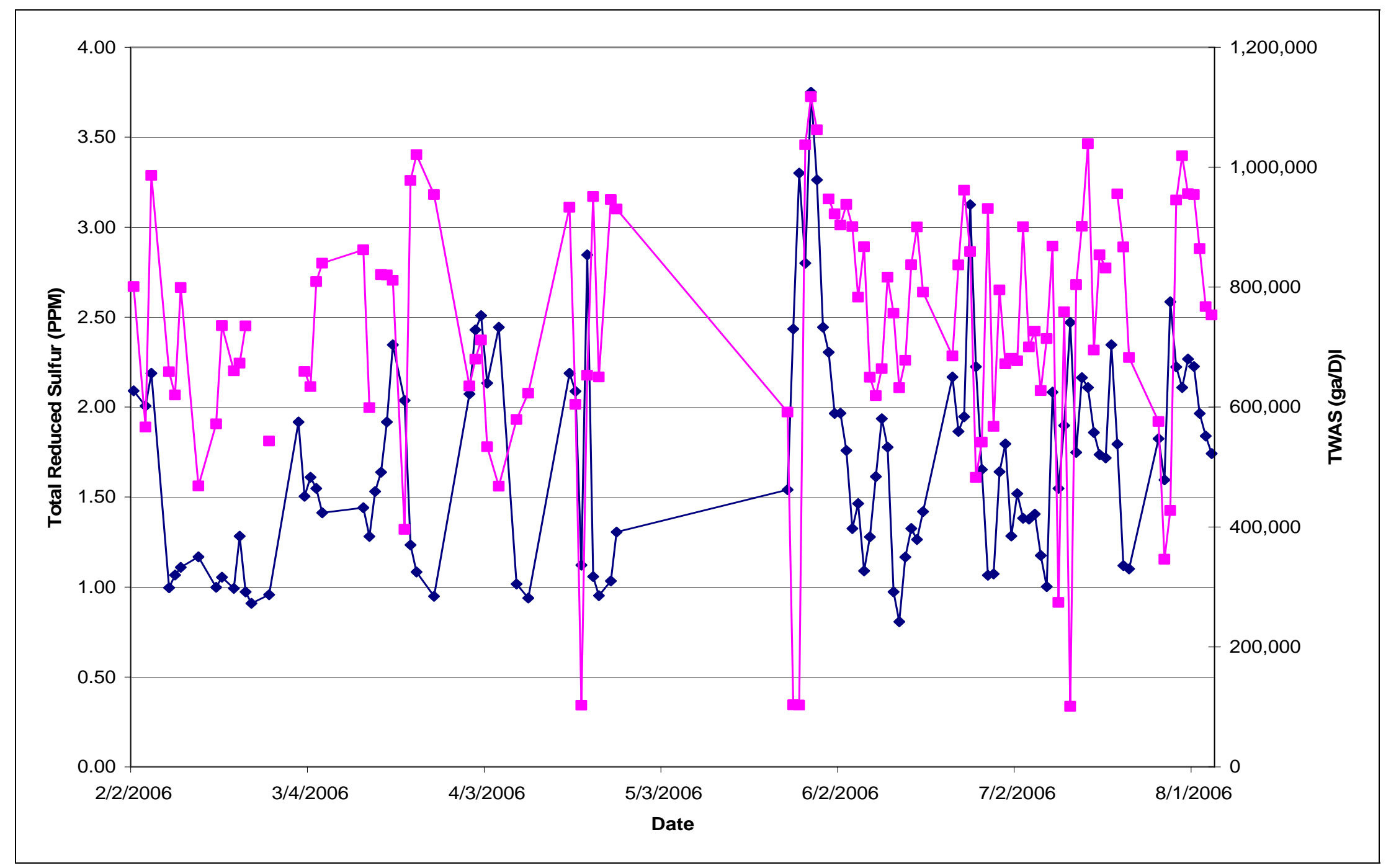

Figure 4-13: Total Reduced Sulfur VS TWAS 


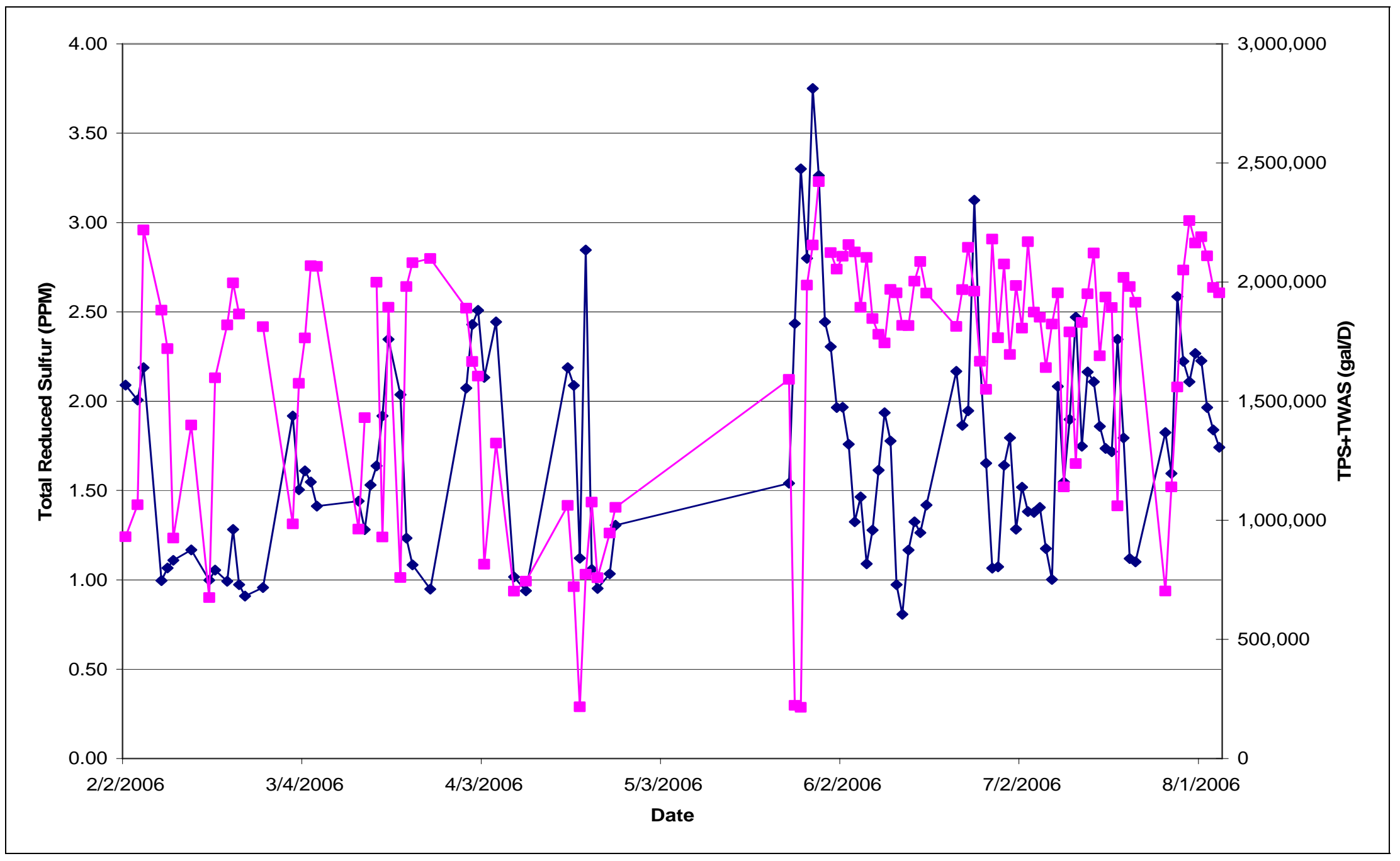

Figure 4-14: Total Reduced Sulfur VS Summation of TPS and TWAS 


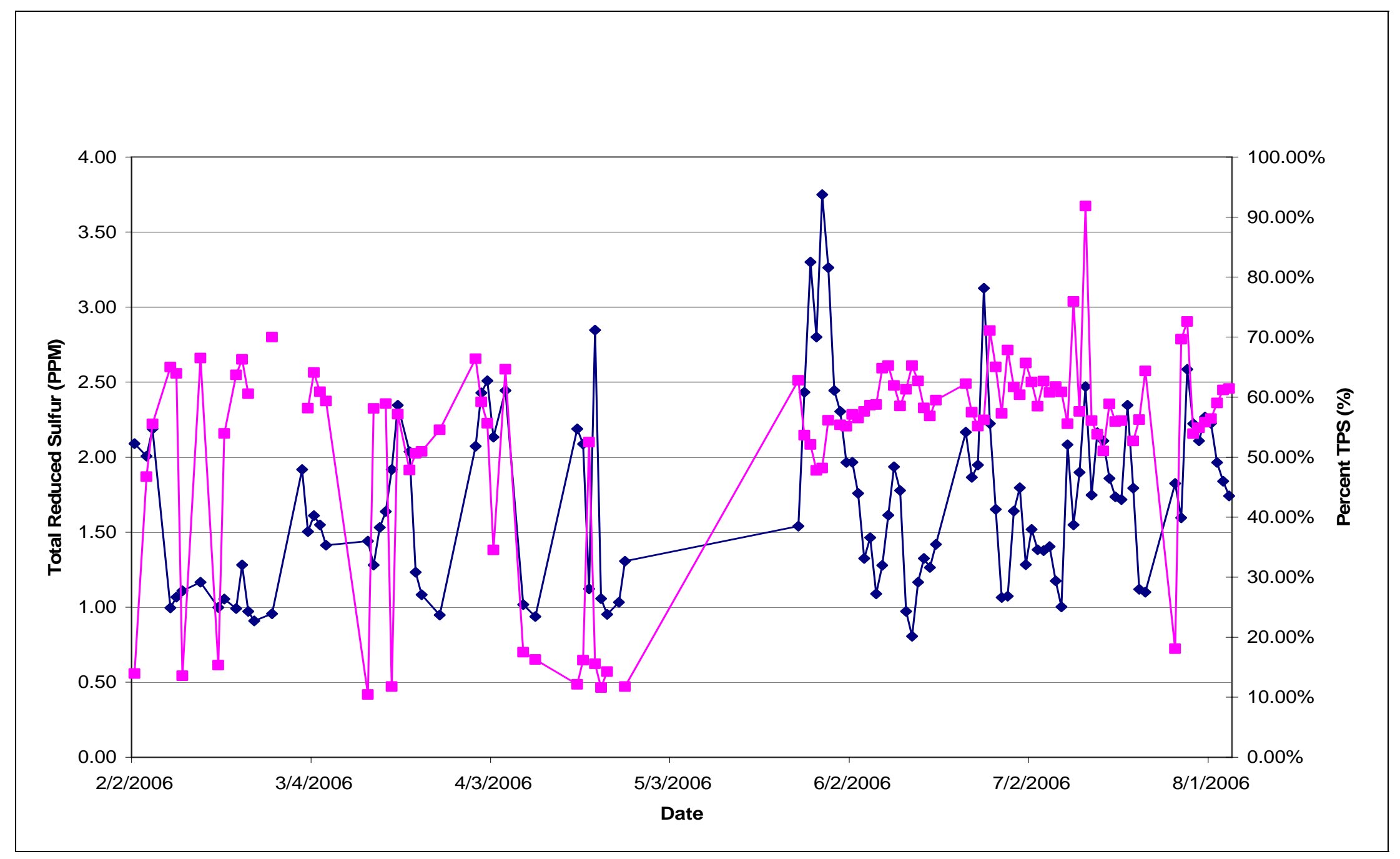

Figure 4-15: Total Reduced Sulfur VS Percent of TPS in Blend Tank 


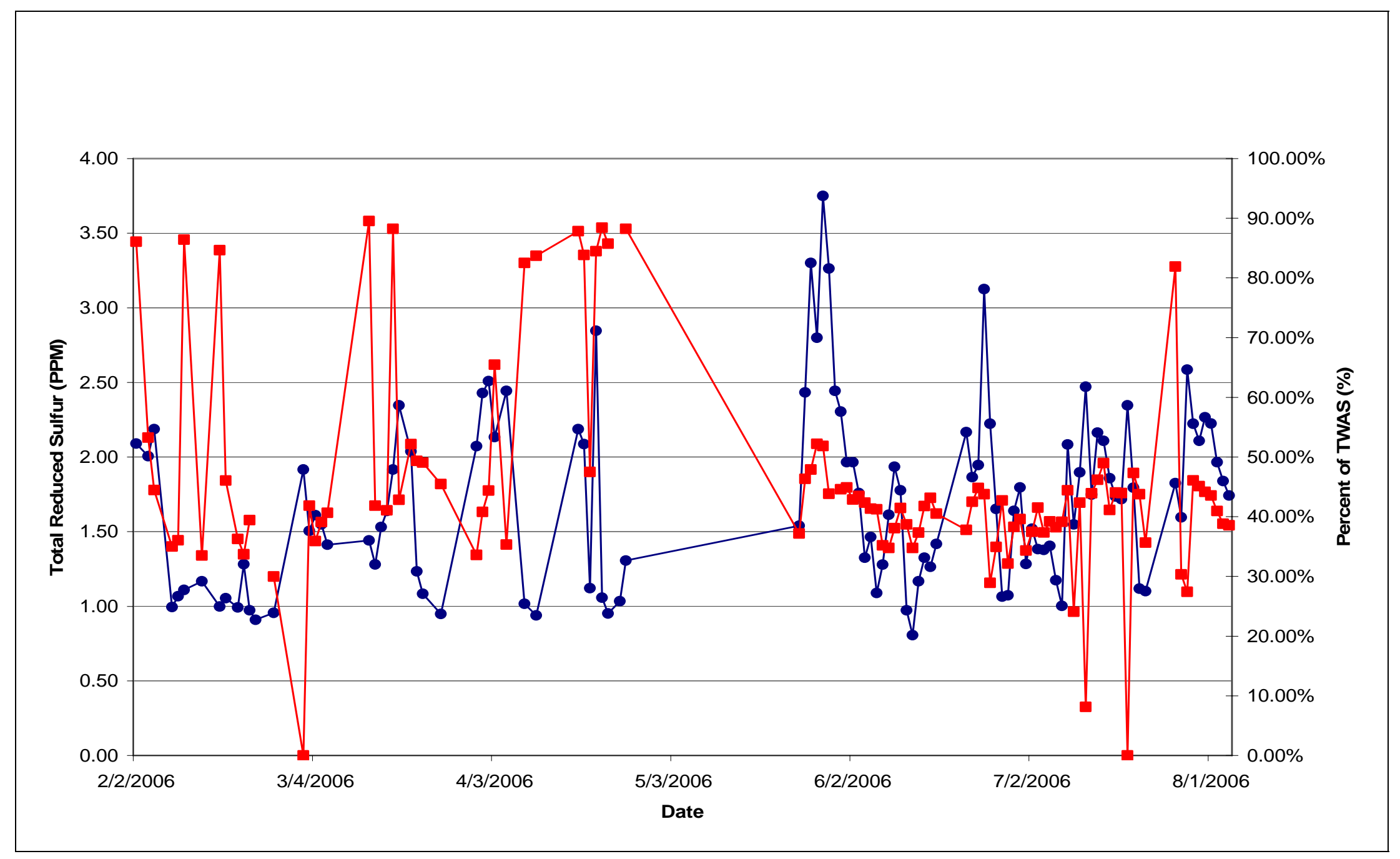

Figure 4-16: Total Reduced Sulfur VS Percent of TWAS in Blend Tank 


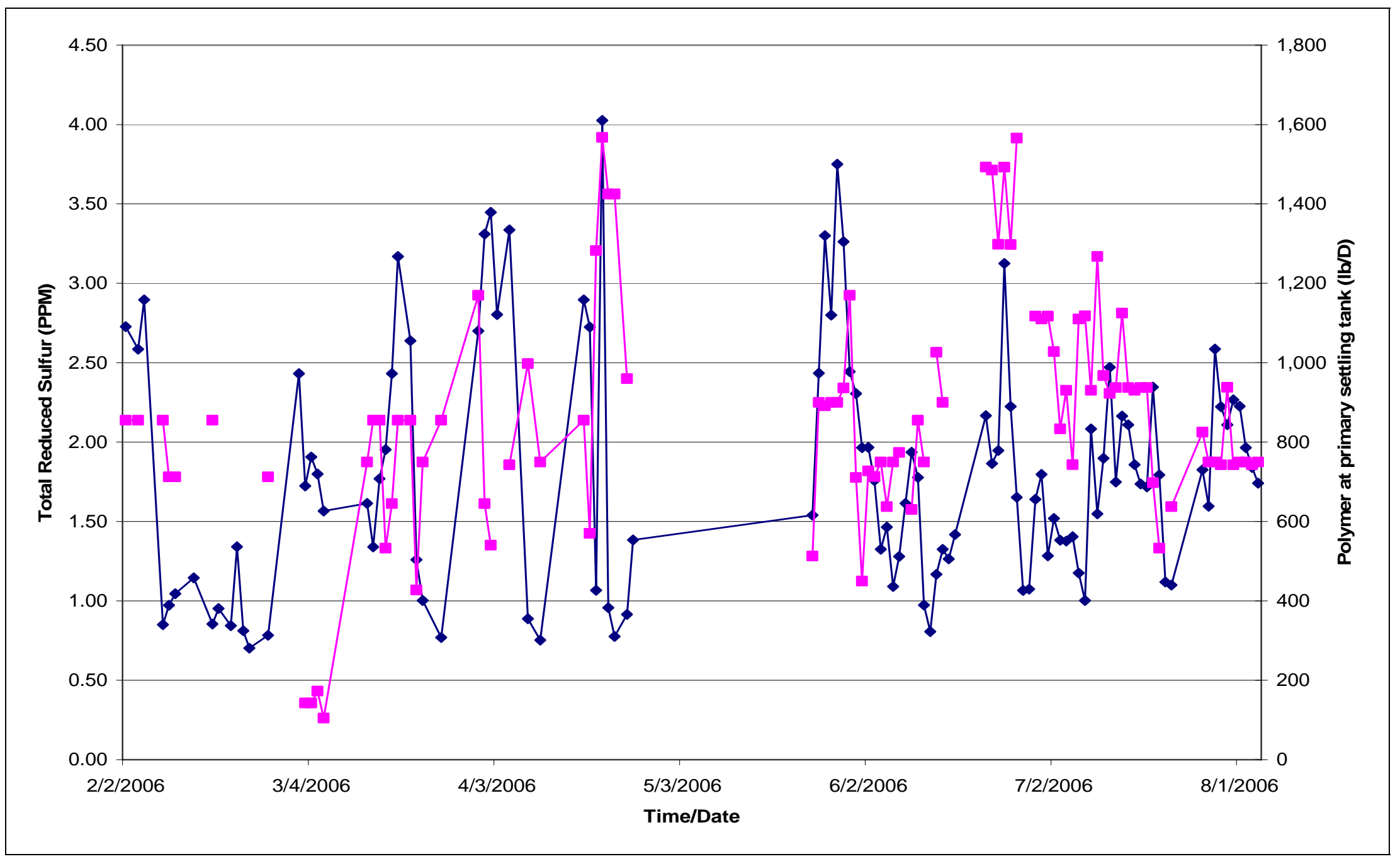

Figure 4-17: Total Reduced Sulfur VS Polymer at primary settling tank 


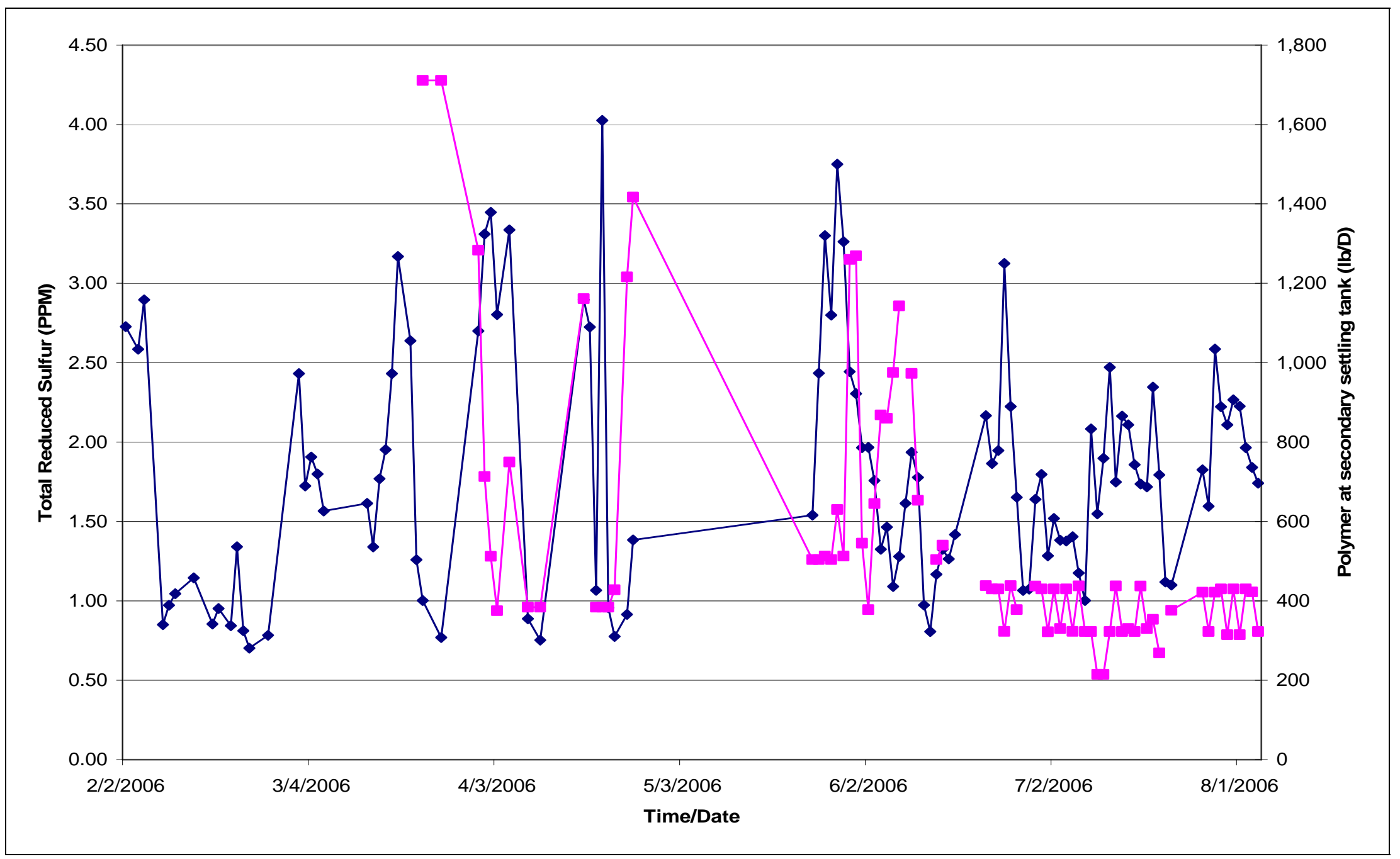

Figure 4-18: Total Reduced Sulfur VS Polymer at secondary settling tank 


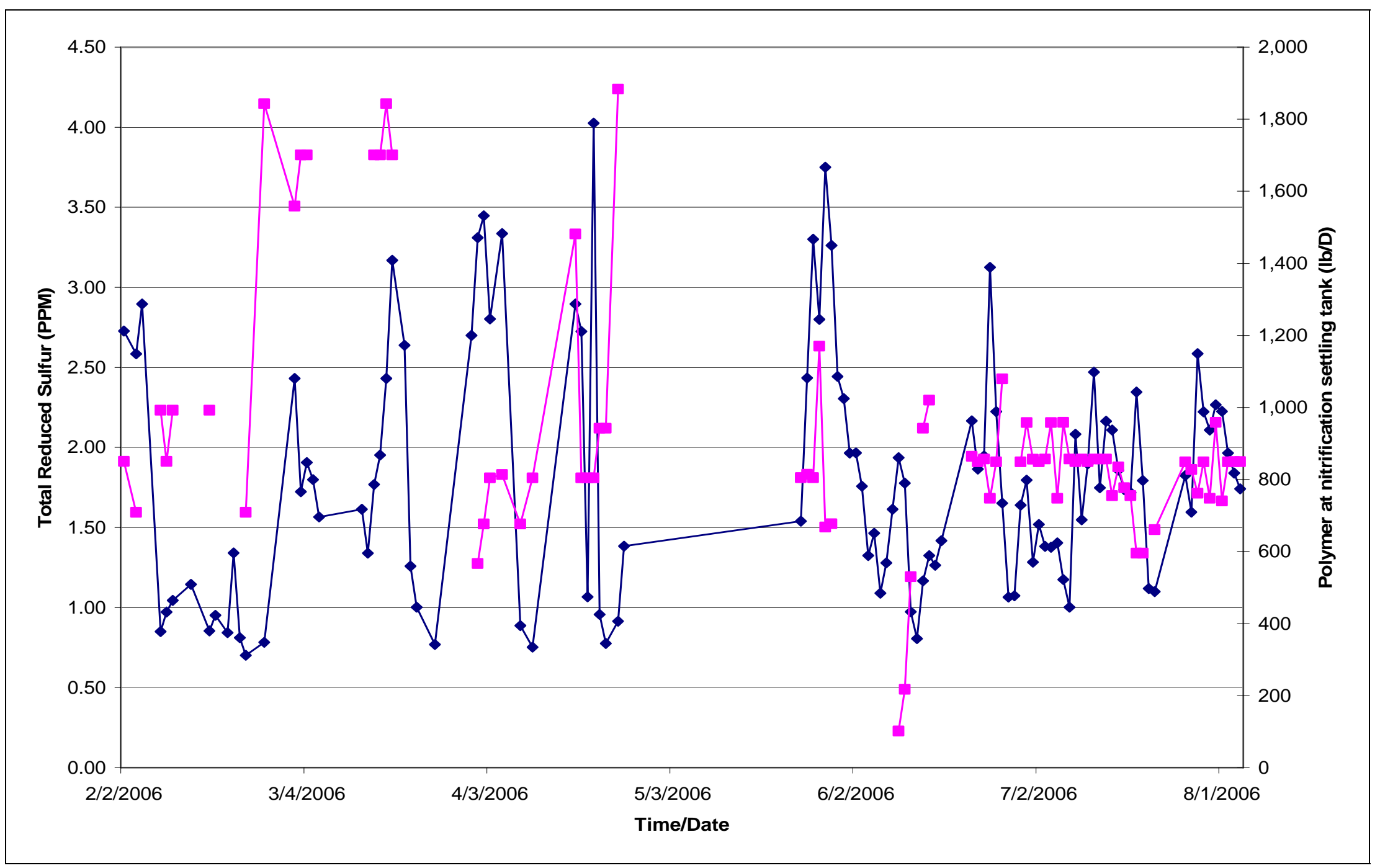

Figure 4-19: Total Reduced Sulfur VS Polymer at Nitrification settling tank 


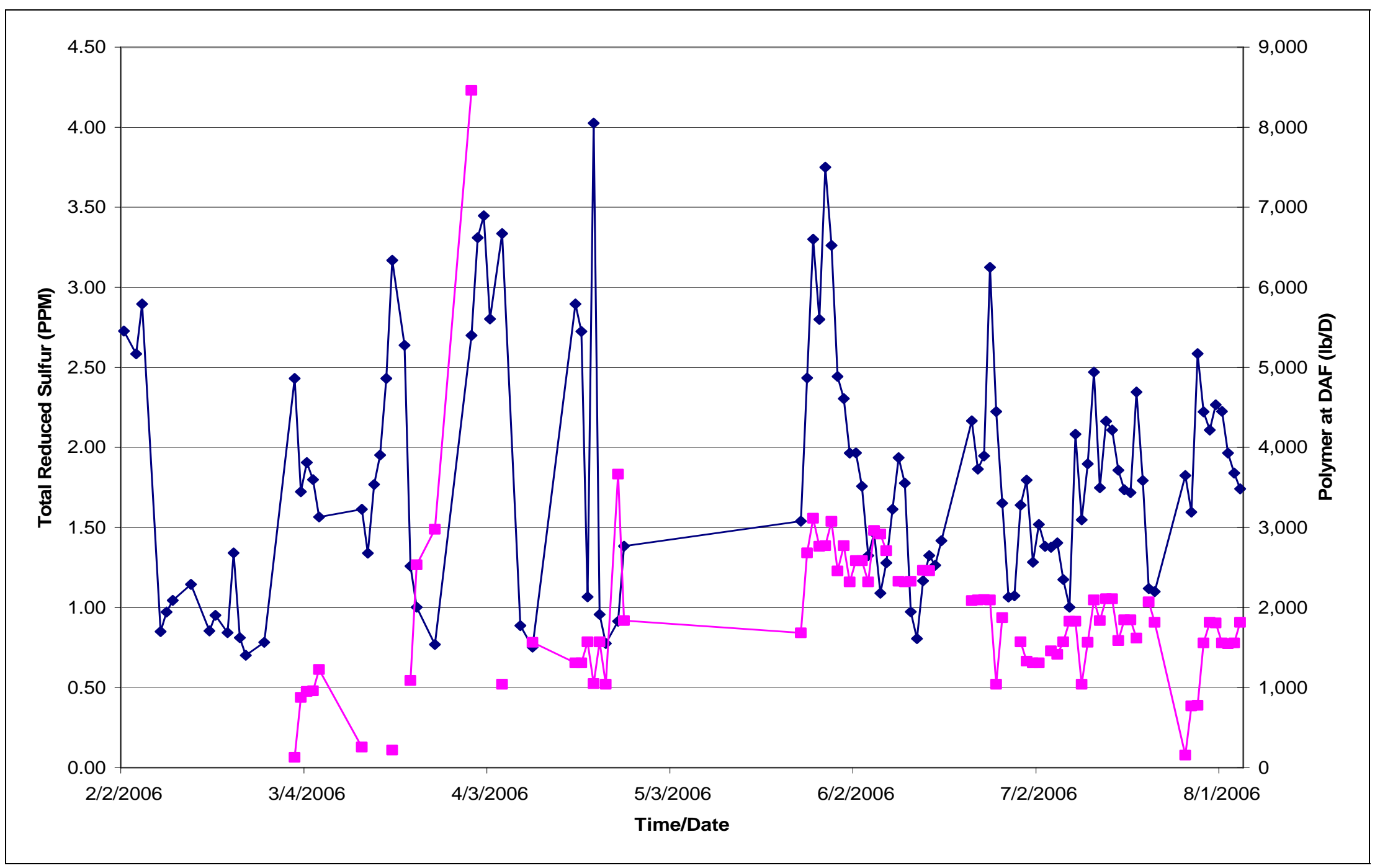

Figure 4-20: Total Reduced Sulfur VS Polymer at DAF 


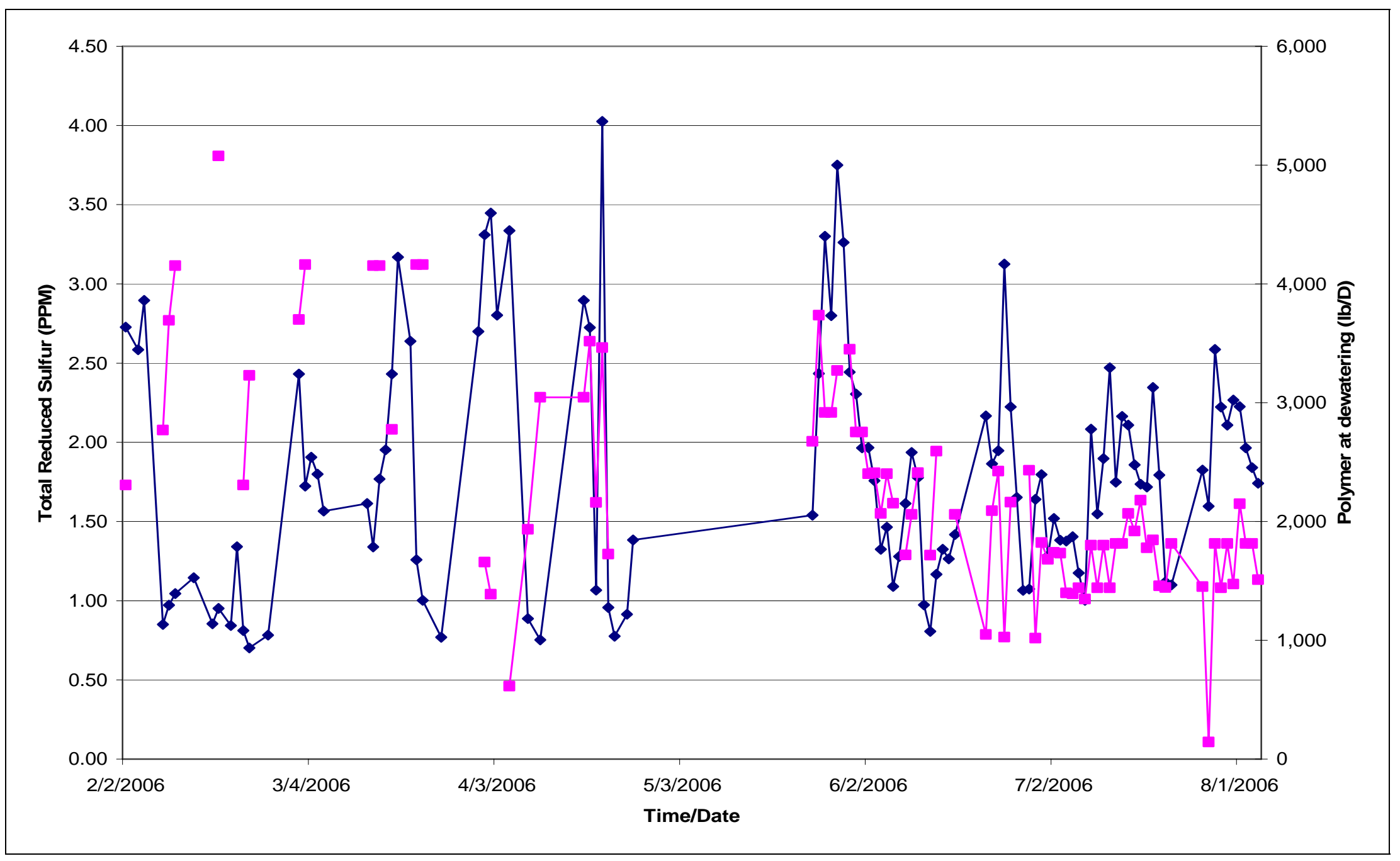

Figure 4-21: Total Reduced Sulfur VS Polymer at Dewatering 
From Figure 4-1 thru 4-21, there are two variables, secondary west odd blanket depth and summation of blanket depth, correlated with volatile sulfur compounds during the entire time span. Since the research divides data into three groups, February to August, February to April and May to August 2006, the result of correlation of each variable will be different. But during May to August, when the device was calibrated, the polymer additions at the dewatering and percent of TWAS in blend tank correlate with total reduced sulfur as well. As DCWASA Department of Wastewater Treatment tried to record all chemical addition to the wastewater treatment process and began setting up a new log sheet system in the middle of April 2006. Therefore all chemical addition such as ferric chloride, waste pickle liquor, sodium hypochlorite and all polymer addition were completely recorded. But data for chemical addition before the middle of April, some data will not be recorded and missing that can be seen from each graph. For this reason, we can not see any graphical correlation between chemical addition and total reduced sulfur during February to April. However, theses are not final decision which variables have strong correlation with total reduced sulfur. The next step for this research was to use the STAT Tool application to compare the result using graphical analysis and select those variables showing the strong correlation.

\subsubsection{Correlation Analysis using STAT Tool}

In probability and statistics, correlation, also call correlation coefficient, is a bivariate measure of association (strength) of the relationship between two variables. It varies from 0 (random relationship) to 1 (perfect linear relationship) or -1 (perfect negative linear relationship). The closer correlation coefficient is to +1 or -1 , the more closely the two variables are related. If correlation coefficient is close to 0 , it means there 
is no relationship between the variables. If correlation coefficient is positive, it means that as one variable gets larger the other gets larger. If correlation coefficient is negative it means that as one gets larger, the other gets smaller (often called an "inverse" correlation). While correlation coefficients are normally reported a value between -1 and +1 , squaring them makes then easier to understand. The square of the coefficient (or $\mathrm{R}$ square) is equal to the percent of the variation in one variable that is related to the variation in the other. For instance, correlation coefficient of 0.5 means $25 \%$ of the variation is related $(0.5$ squared $=0.25$.) The correlation coefficient value of 0.7 means $49 \%$ of the variance is related $(0.7$ square $=0.49$.

As this research would like to find the variables that strongly contribute to the odor level releasing from biosolids, we will select the process variables $\left(\mathrm{x}_{1}, \mathrm{x}_{2}, \ldots \ldots, \mathrm{x}_{\mathrm{n}}\right)$ that have correlation with total volatile reduced sulfur (y), but among those process variables must not have correlation with one another. The term multicollinearity (or collinearity) is used to describe the situation when a high correlation is detected between two or more independent variables. For instance, such high correlations cause problems when trying to draw inferences about the relative contribution of each independent variable to the success of the model. For this reason, even though we can find the process variables that have strong correlation with total volatile reduced sulfur, we have to check the correlation among those variables, and some of them may not be used in the regression model which can be seen in Section 4.2. According to Peot (2006), the maximum of retention time of process variables from upstream process through the dewatering process will be one day. Therefore, the previous data (D-1) of process variables except polymer addition at dewatering will be used with real time monitoring 
data in correlation analysis. For instance, we use monitoring data today but use process variables from yesterday to analyze. In this research uses STAT Tool application to find correlation and regression analysis. To find correlation, firstly we have arrange all data, total volatile reduced sulfur data and process variables data in the same form and then plug in STAT Tool application. The variables considered to be strong correlation with total volatile reduced sulfur must relate with the result of graphical analysis. The example of input data of both process variables and total volatile reduced sulfur can be seen in Table 4-1. Because of the calibration issue during February to April, this research can be divided into three duration groups, February- August, February- April and May -August. Correlation for each duration is discussed in Section 4.1.3 to 4.1.5 and summarized in Table 4-2 to Table 4-4. 
Table 4-1: The sample input data of process variables (D-1) and total reduced sulfur using in STAT Tool for correlation analysis

\begin{tabular}{|c|c|c|c|c|c|c|c|c|c|c|c|c|c|c|c|c|}
\hline Date & (g/D) & $\begin{array}{c}\text { Poly } \\
\text { mer } \\
\text { at } \\
\text { Secon } \\
\text { dary } \\
\text { (lb/D) }\end{array}$ & $\begin{array}{l}\text { Polymer } \\
\text { at } \\
\text { Nitrifica } \\
\text { tion } \\
\text { (lb/D) }\end{array}$ & $\begin{array}{l}\text { Polymer } \\
\text { at DAF }\end{array}$ & $\begin{array}{l}\text { Polymer } \\
\text { at } \\
\text { Dewater } \\
\text {-ing } \\
\text { (lb/D) }\end{array}$ & (g/D) & $\begin{array}{l}\mathrm{NaO} \\
\mathrm{Cl}\end{array}$ & $\begin{array}{l}\text { Secondary } \\
\text { east } \\
\text { blanket } \\
\text { depth } \\
\text { (Feet) }\end{array}$ & $\begin{array}{l}\text { Secondary } \\
\text { west odd } \\
\text { blanket } \\
\text { depth } \\
\text { (Feet) }\end{array}$ & $\begin{array}{l}\% \\
\text { solid } \\
\text { of GT } \\
\text { in } \\
\text { blend } \\
(\%) \\
\end{array}$ & $\begin{array}{l}\% \\
\text { solid } \\
\text { of } \\
\text { DAF } \\
\text { in } \\
\text { blend } \\
(\%)\end{array}$ & $\begin{array}{l}\% \\
\text { TPS } \\
\text { in } \\
\text { blend } \\
\text { tank } \\
\\
(\%) \\
\end{array}$ & $\begin{array}{l}\% \\
\text { TWA } \\
S \text { in } \\
\text { blend } \\
\text { tank } \\
(\%) \\
\end{array}$ & 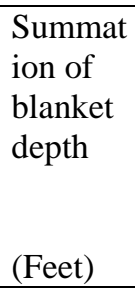 & $\begin{array}{l}\text { Polymer } \\
\text { at } \\
\text { Primary } \\
\text { settling } \\
\text { (lb/D) }\end{array}$ & $\begin{array}{l}\text { Total } \\
\text { Redu } \\
\text { ced } \\
\text { Sulfur }\end{array}$ \\
\hline $5 / 24 / 06$ & 8,253 & 512 & 2,112 & 1,414 & 667 & 9,908 & 8,736 & 2.2 & 3.8 & 64.66 & 35.34 & 62.82 & 37.18 & 6.0 & 427 & 1.54 \\
\hline $5 / 25 / 06$ & 7,963 & 512 & 3,274 & 2,253 & 660 & 9,856 & 8,709 & 2.8 & 4.3 & 53.99 & 46.01 & 53.67 & 46.33 & 7.1 & 750 & $2 ., 43$ \\
\hline $5 / 26 / 06$ & 7,993 & 521 & 3,383 & 2,616 & 660 & 9,857 & 8,684 & 2.8 & 3.6 & 58.64 & 41.36 & 52.10 & 47.90 & 6.4 & 743 & 3.30 \\
\hline $5 / 27 / 06$ & 7,843 & 512 & 3,082 & 2,321 & 548 & 9,632 & 7,656 & 2.9 & 3.8 & 55.95 & 44.05 & 47.78 & 52.22 & 6.7 & 750 & 2.80 \\
\hline $5 / 28 / 06$ & 8,120 & 640 & 4,106 & 2,328 & 555 & 9,850 & 7,656 & 2.8 & 3.6 & 57.31 & 42.69 & 48.17 & 51.83 & 6.4 & 750 & 3.75 \\
\hline $5 / 29 / 06$ & 8,171 & 521 & 3,804 & 2,586 & & 9,850 & 7,656 & 2.8 & 3.4 & 60.66 & 39.34 & 56.14 & 45.86 & 6.2 & 795 & 3.26 \\
\hline$\ldots .$. & $\ldots \ldots$ & $\ldots \ldots$ & $\ldots \ldots$ & $\ldots \ldots$ & $\ldots \ldots$ & $\ldots \ldots$ & $\ldots \ldots$ & $\ldots \ldots$ & $\ldots \ldots$ & $\ldots \ldots$ & $\ldots \ldots$ & $\ldots \ldots$ & $\ldots \ldots$ & $\ldots$ & $\ldots$ & \\
\hline
\end{tabular}


Table 4-2: Correlation between process variables (D-1) and total reduced sulfur from February to August 2006

\begin{tabular}{|l|l|l|l|l|l|l|l|l|l|l|l|l|}
\hline Variables & FeCl3 & WPL & $\begin{array}{l}\text { Summati } \\
\text { on of } \\
\text { FeCl3 } \\
\text { and WPL }\end{array}$ & NaOCl & $\begin{array}{l}\text { Secondary } \\
\text { east } \\
\text { blanket } \\
\text { depth }\end{array}$ & $\begin{array}{l}\text { RAS } \\
\text { east }\end{array}$ & $\begin{array}{l}\text { Secondary } \\
\text { west odd } \\
\text { blanket } \\
\text { depth }\end{array}$ & $\begin{array}{l}\text { RAS } \\
\text { west }\end{array}$ & $\begin{array}{l}\text { \% } \\
\text { solid } \\
\text { of GT } \\
\text { in } \\
\text { blend }\end{array}$ & $\begin{array}{l}\text { \% solid } \\
\text { of DAF } \\
\text { in blend }\end{array}$ & TPS & TWAS \\
\hline $\begin{array}{l}\text { total } \\
\text { reduced } \\
\text { sulfur }\end{array}$ & 0.041 & -0.178 & -0.144 & 0.120 & 0.039 & 0.136 & 0.384 & 0.078 & 0.071 & -0.096 & -0.034 & 0.109 \\
\hline
\end{tabular}

Table 4-2: Correlation between process variables (D-1) and total reduced sulfur from February to August 2006 (Continued)

\begin{tabular}{|l|l|l|l|l|l|l|l|l|}
\hline Variables & $\begin{array}{l}\text { \% TPS } \\
\text { in blend } \\
\text { tank }\end{array}$ & $\begin{array}{l}\text { \% } \\
\text { TWAS } \\
\text { in blend } \\
\text { tank }\end{array}$ & $\begin{array}{l}\text { Sum of } \\
\text { blanket } \\
\text { depth }\end{array}$ & $\begin{array}{l}\text { Polymer } \\
\text { at } \\
\text { Primary } \\
\text { settling }\end{array}$ & $\begin{array}{c}\text { Polymer } \\
\text { at } \\
\text { Secondary }\end{array}$ & $\begin{array}{c}\text { Polymer } \\
\text { at } \\
\text { Nitrification }\end{array}$ & $\begin{array}{l}\text { Polymer } \\
\text { at DAF }\end{array}$ & $\begin{array}{l}\text { Polymer at } \\
\text { Dewatering }\end{array}$ \\
\hline $\begin{array}{l}\text { total } \\
\text { reduced } \\
\text { sulfur }\end{array}$ & -0.023 & 0.023 & 0.301 & 0.116 & -0.143 & -0.148 & 0.102 & -0.094 \\
\hline
\end{tabular}


4.1.3 Correlation between process variables and total reduced sulfur from February to August 2006

From Table 4-2 which is the overall correlation from February to August, we found that the process variables, secondary west odd blanket and summation of secondary blanket have a positive correlation with total reduced Sulfur. This is shown in correlation coefficient (R):

Secondary west odd blanket depth, $\mathrm{R}=0.384$

Summation of secondary blanket depth $\mathrm{R}=0.301$

To compare these two variables with Figure 4-7 and Figure 4-9, indicates that the two variables have correlation with total reduced sulfur. According to Vilalai (2003), the higher the sludge blanket in the secondary sedimentation tanks, the greater the retention time of the waste activated sludge before removing to the DAF thickeners, and the more potential for promote odor level in biosolids after dewatering. Additionally, the study by Sekyiamah (2005) suggested that concentration of reduced sulfur at the bottom of secondary settling tank strongly correlates with the sludge blanket level or the higher the sludge blanket level the greater reduced sulfur produced. In another recent study, Gabriel, et al. (2006) showed that the blanket depth from the day before have the greatest change on the biosolids odor level. But, the correlation of the secondary east blanket is 0.039 which represents virtually no correlation with total reduced sulfur, however only the secondary west odd blanket has a positive correlation with total reduced sulfur. Since the summation of secondary blanket depth is the product between of west odd blanket and east blanket which is a weak correlation with total reduced sulfur, it will make the correlation of summation of secondary blanket depth a little bit lower. Therefore, the 
correlation of summation of secondary blanket depth is lower than the secondary west odd blanket depth. In addition, these two process variables have a strong correlation with each other called multicollinearity in which $\mathrm{R}$ is 0.803 . The reason for this multicollinearity was mentioned previously, and will be discussed later in the next topic, connection with regression analysis. For this period, the secondary west odd blanket has the strongest correlation with total reduced sulfur. The scatter plots in Figure 4-22 and Figure 4-23 can be used to explain and support the correlation between those two independent variables and total reduced sulfur.

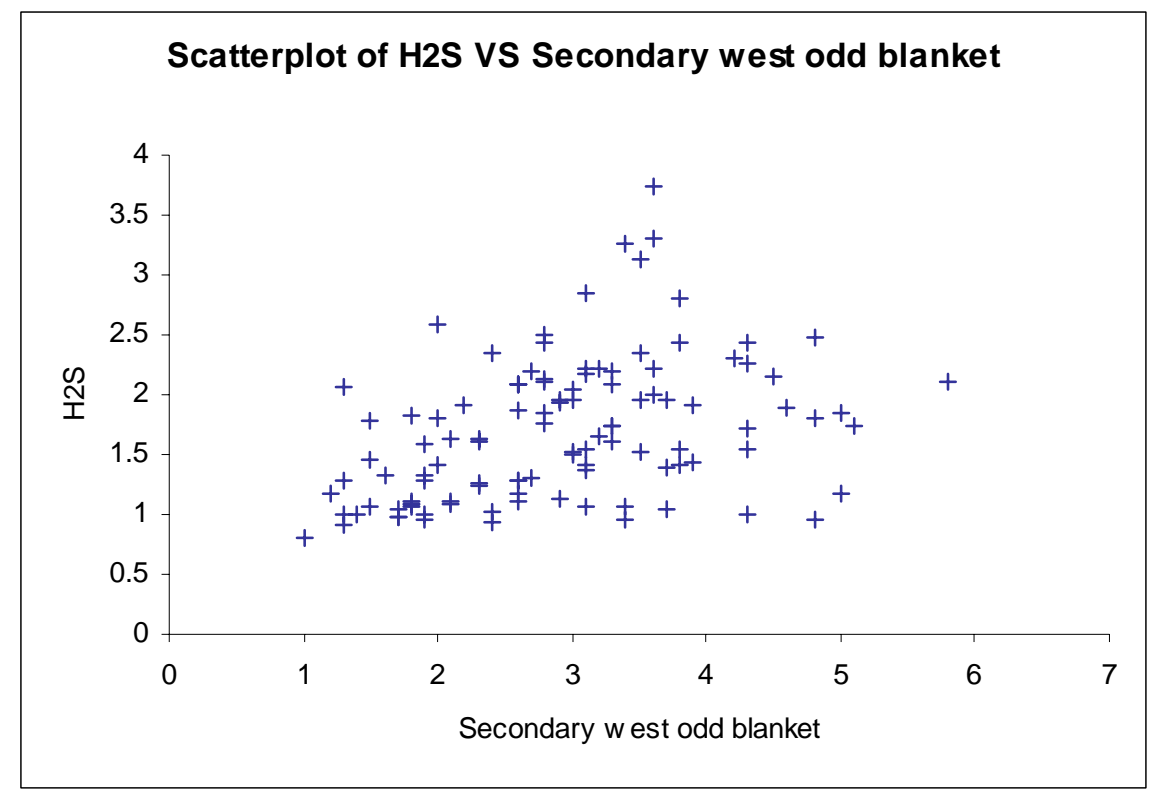

Figure 4-22: Scatter plot total reduced sulfur VS Secondary west odd blanket 


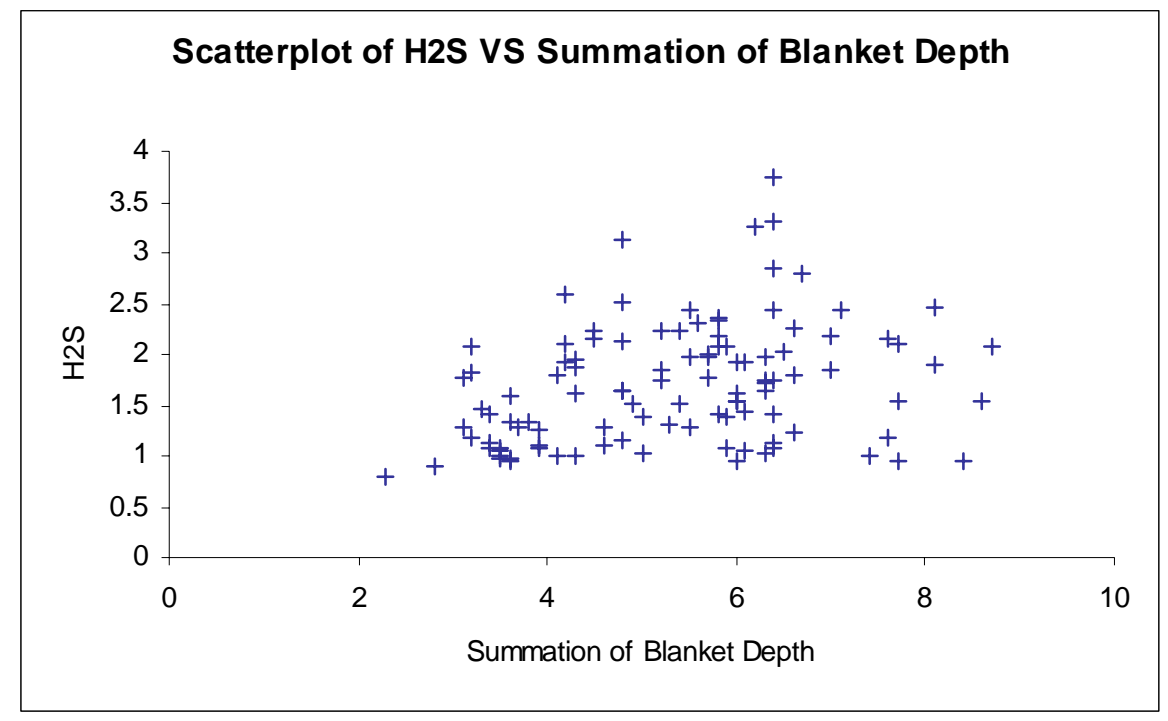

Figure 4-23: Scatter plot total reduced sulfur VS Sum of the blanket depth

4.1.4 Correlation between process variables and total reduced sulfur from February to April 2006

From Table 4-3, three process variables, return activated sludge (RAS) east, secondary west odd blanket and summation of blanket depth are the strongest correlation with total reduced sulfur. The correlation coefficient $(\mathrm{R})$ for each variable:

RAS East, $\mathrm{R}=0.32$

Secondary west odd blanket depth, $\mathrm{R}=0.284$

Summation of blanket depth, $\mathrm{R}=0.247$

The RAS east has positive sign with total reduced sulfur which means the more RAS east the greater the odor level produced. According to Sekyiamah (2005), the bottom of sedimentation tank is a significant source of VSC. For the flow pattern of the secondary process, RAS east was pumped from the bottom of the sedimentation tank and 
Table 4-3: Correlation between Process Variables (D-1) and total reduced sulfur from February to April 2006

\begin{tabular}{|l|l|l|l|l|l|l|l|l|l|l|l|l|}
\hline Variables & FeCl3 & WPL & $\begin{array}{l}\text { Summati } \\
\text { on of } \\
\text { FeCl3 } \\
\text { and WPL }\end{array}$ & NaOCl & $\begin{array}{l}\text { Secondary } \\
\text { east } \\
\text { blanket } \\
\text { depth }\end{array}$ & $\begin{array}{l}\text { RAS } \\
\text { east }\end{array}$ & $\begin{array}{l}\text { Secondary } \\
\text { west odd } \\
\text { blanket } \\
\text { depth }\end{array}$ & $\begin{array}{l}\text { RAS } \\
\text { west }\end{array}$ & $\begin{array}{l}\text { \% solid } \\
\text { of GT } \\
\text { in blend }\end{array}$ & $\begin{array}{l}\text { \% solid of } \\
\text { DAF in } \\
\text { blend }\end{array}$ & TPS & TWAS \\
\hline $\begin{array}{l}\text { total } \\
\text { reduced } \\
\text { sulfur }\end{array}$ & -0.141 & -0.166 & -0.141 & 0.008 & 0.048 & 0.320 & 0.284 & 0.109 & -0.006 & -0.043 & -0.070 & 0.097 \\
\hline
\end{tabular}

Table 4-3: Correlation between Process Variables (D-1) and total reduced sulfur from February to April 2006 (Continued)

\begin{tabular}{|l|l|l|l|l|l|l|l|l|}
\hline Variables & $\begin{array}{l}\text { \% } \\
\text { TPS in } \\
\text { blend } \\
\text { tank }\end{array}$ & $\begin{array}{l}\text { \% } \\
\text { TWAS } \\
\text { in blend } \\
\text { tank }\end{array}$ & $\begin{array}{l}\text { Sum of } \\
\text { blanket } \\
\text { depth }\end{array}$ & $\begin{array}{l}\text { Polymer } \\
\text { at } \\
\text { Primary } \\
\text { settling }\end{array}$ & $\begin{array}{c}\text { Polymer } \\
\text { at } \\
\text { Secondary }\end{array}$ & $\begin{array}{c}\text { Polymer } \\
\text { at } \\
\text { Nitrification }\end{array}$ & $\begin{array}{l}\text { Polymer } \\
\text { at DAF }\end{array}$ & $\begin{array}{l}\text { Polymer at } \\
\text { Dewatering }\end{array}$ \\
\hline $\begin{array}{l}\text { total } \\
\text { reduced } \\
\text { sulfur }\end{array}$ & -0.066 & 0.066 & 0.247 & -0.010 & -0.185 & -0.132 & -0.065 & -0.346 \\
\hline
\end{tabular}


returned to the influent of the secondary east reactor. But RAS west has a weak correlation with total reduced sulfur. In addition, the secondary west odd blanket depth still has a positive sign with total reduced sulfur. That means it is a significant source to promote of odor in biosolids, which means that the higher the secondary west odd blanket level, the greater the odor produced. But there is another process variable, polymer at dewatering, that has a high correlation coefficient as well. However, this time frame doesn't include polymer at dewatering in the regression analysis because data are missing as shown in Figure 3-8 and 4-21. Since we know some recordings for February to April were missing, DCWASA Department of Wastewater Treatment began setting up the new system for recording data and started recording process data after April. For this reason, polymer addition at dewatering can’t be included in the regression analysis during for this period. Comparing the correlation result of these three variables with graphical analysis during this period, the secondary west odd blanket shown in Figure 4-7 correlates closely with total reduced sulfur.

For multicollinearity, the correlation between secondary west odd blanket and summation of blanket is 0.757 , the correlation between RAS East and secondary west odd blanket is 0.470, and between RAS East and summation of blanket depth is 0.619 . Therefore correlation between the secondary west odd blanket and the summation of blanket depth is still high and similar to the February - August period. The scatter plots in Figure 4-24 to 4-26 show the relation of three variables and total reduced sulfur. 


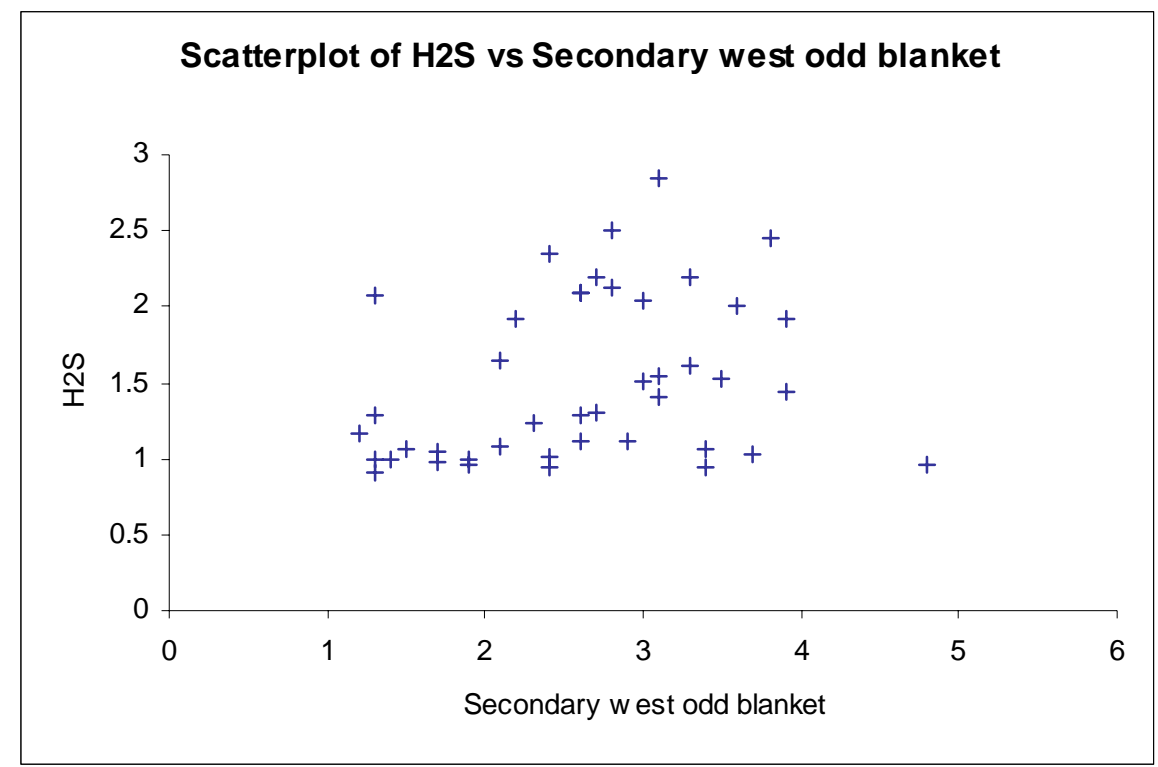

Figure 4-24: Scatter plot total reduced sulfur VS Secondary west odd blanket

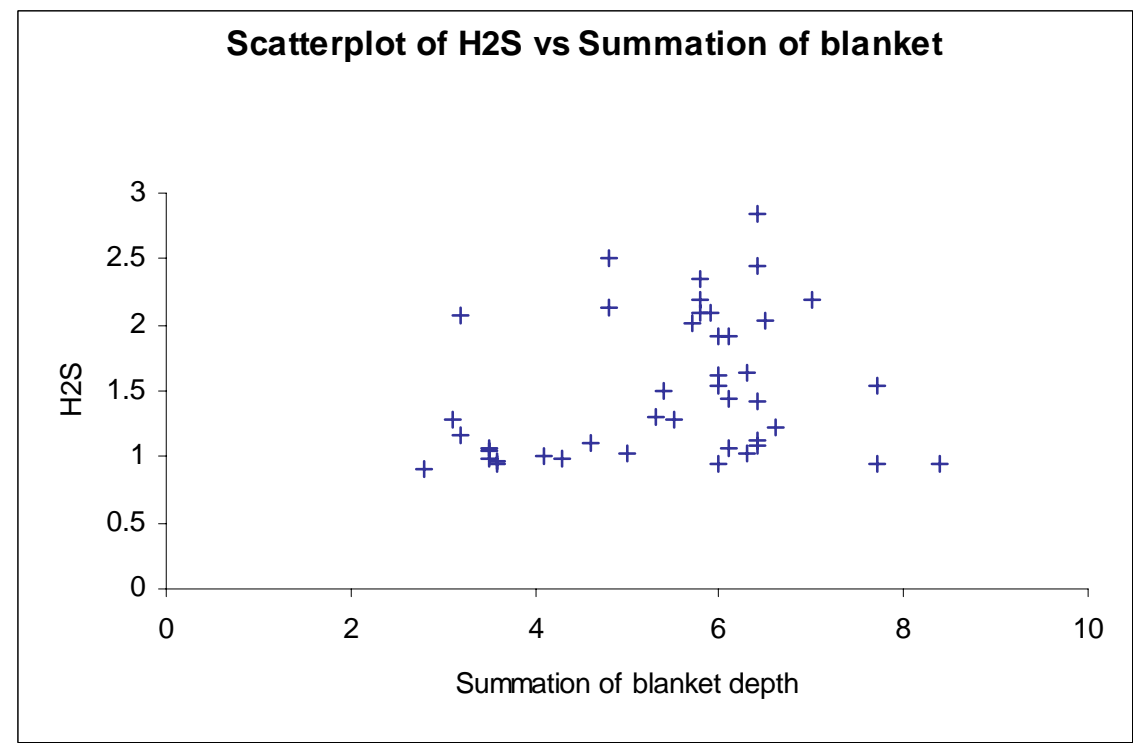

Figure 4-25: Scatter plot total reduced sulfur VS Sum of the blanket 


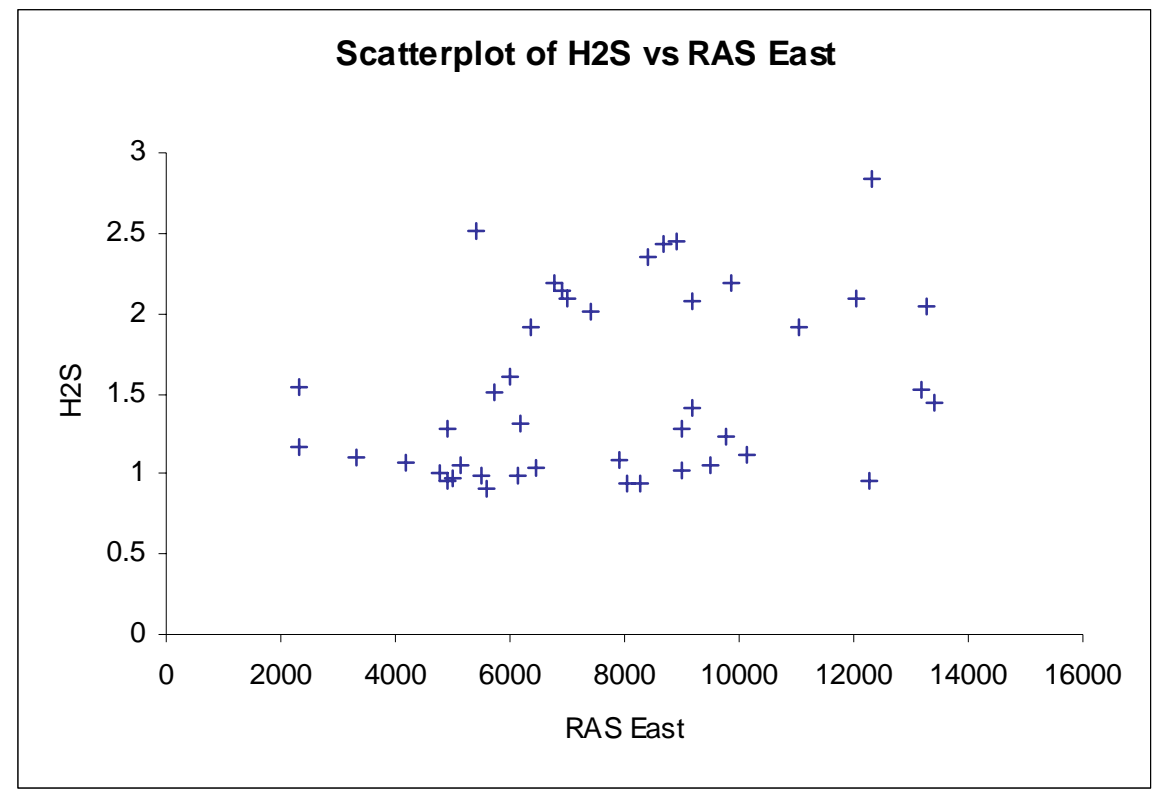

Figure 4-26: Scatter plot of total reduced sulfur VS RAS east

4.1.5 Correlation between process variables and total reduced sulfur from May to August 2006

In this period, there are three process variables, secondary west odd blanket, summation of blanket depth and polymer addition at dewatering, that have high correlation with total reduced sulfur. As both devices were calibrated in the middle of May and DCWASA began recording all chemical addition, this period should be more reliable. From Table 4-4, the correlation coefficients of each variable are:

Secondary west odd blanket $=0.370$

Summation of blanket depth $=0.366$

Polymer addition at dewatering $=0.339$

The secondary west odd blanket still has a positive sign with total reduced sulfur, and is the significant variable in contributing odor after the dewatering process: the higher the secondary west odd blanket level then the greater the odor level. Once again the present 
Table 4-4: Correlation between process variables (D-1) and total reduced sulfur from May to August 2006

\begin{tabular}{|l|l|l|l|l|l|l|l|l|l|l|l|l|}
\hline Variables & FeCl3 & WPL & $\begin{array}{l}\text { Summati } \\
\text { on of } \\
\text { FeCl3 } \\
\text { and WPL }\end{array}$ & NaOCl & $\begin{array}{l}\text { Secondary } \\
\text { east } \\
\text { blanket } \\
\text { depth }\end{array}$ & $\begin{array}{l}\text { RAS } \\
\text { east }\end{array}$ & $\begin{array}{l}\text { Secondary } \\
\text { west odd } \\
\text { blanket } \\
\text { depth }\end{array}$ & $\begin{array}{l}\text { RAS } \\
\text { west }\end{array}$ & $\begin{array}{l}\text { \% solid } \\
\text { of GT } \\
\text { in blend }\end{array}$ & $\begin{array}{l}\text { \% solid of } \\
\text { DAF in } \\
\text { blend }\end{array}$ & TPS & TWAS \\
\hline $\begin{array}{l}\text { Total } \\
\text { Reduce } \\
\text { Sulfur }\end{array}$ & 0.002 & -0.113 & -0.094 & 0.078 & 0.206 & 0.024 & 0.370 & 0.185 & -0.037 & 0.040 & -0.287 & 0.119 \\
\hline
\end{tabular}

Table 4-4: Correlation between process variables (D-1) and total reduced sulfur from May to August 2006 (Continued)

\begin{tabular}{|l|l|l|l|l|l|l|l|l|}
\hline Variables & $\begin{array}{l}\text { \% TPS } \\
\text { in blend } \\
\text { tank }\end{array}$ & $\begin{array}{l}\text { \% } \\
\text { TWAS } \\
\text { in blend } \\
\text { tank }\end{array}$ & $\begin{array}{l}\text { Sum of } \\
\text { blanket } \\
\text { depth }\end{array}$ & $\begin{array}{l}\text { Polymer } \\
\text { at } \\
\text { Primary } \\
\text { settling }\end{array}$ & $\begin{array}{c}\text { Polymer } \\
\text { at } \\
\text { Secondary }\end{array}$ & $\begin{array}{c}\text { Polymer } \\
\text { at } \\
\text { Nitrification }\end{array}$ & $\begin{array}{l}\text { Polymer } \\
\text { at DAF }\end{array}$ & $\begin{array}{l}\text { Polymer at } \\
\text { Dewatering }\end{array}$ \\
\hline $\begin{array}{l}\text { Total } \\
\text { Reduce }\end{array}$ & -0.238 & 0.238 & 0.366 & 0.113 & 0.007 & -0.141 & 0.243 & 0.339 \\
\hline
\end{tabular}


research can support the recent study of Sekyiamah (2005) and Gabriel, et al. (2006). The correlation between secondary west odd blanket and summation of blanket depth is high. Polymer addition at dewatering has a positive sign with total reduced sulfur. That means the more polymers added the greater the odor level produced. The main purpose of polymer addition at dewatering is to promote flocculation on sludge particles stick together and to assist centrifuges in removing water from sludge easily. According to DCWASA, there is not information to show that the polymer addition at dewatering process causes higher reduced volatile sulfur compounds in biosolids, but this research found this variable has a correlation with total reduced sulfur and can be a factor that shows increase odor level. Therefore, it must be investigated further by laboratory experiments, and the results compared with this analysis. In addition, there are the other variables; the percent of TPS in the blend tank, the percent of TWAS in the blend tank, and polymer at DAF, which still have correlation with total reduced sulfur even though they are not strong correlation. However, some of them will used in this research if they show signs of increasing odor in biosolids. The scatter plots of three variables VS total reduced sulfur show in Figure 4-27 to 4-29. 


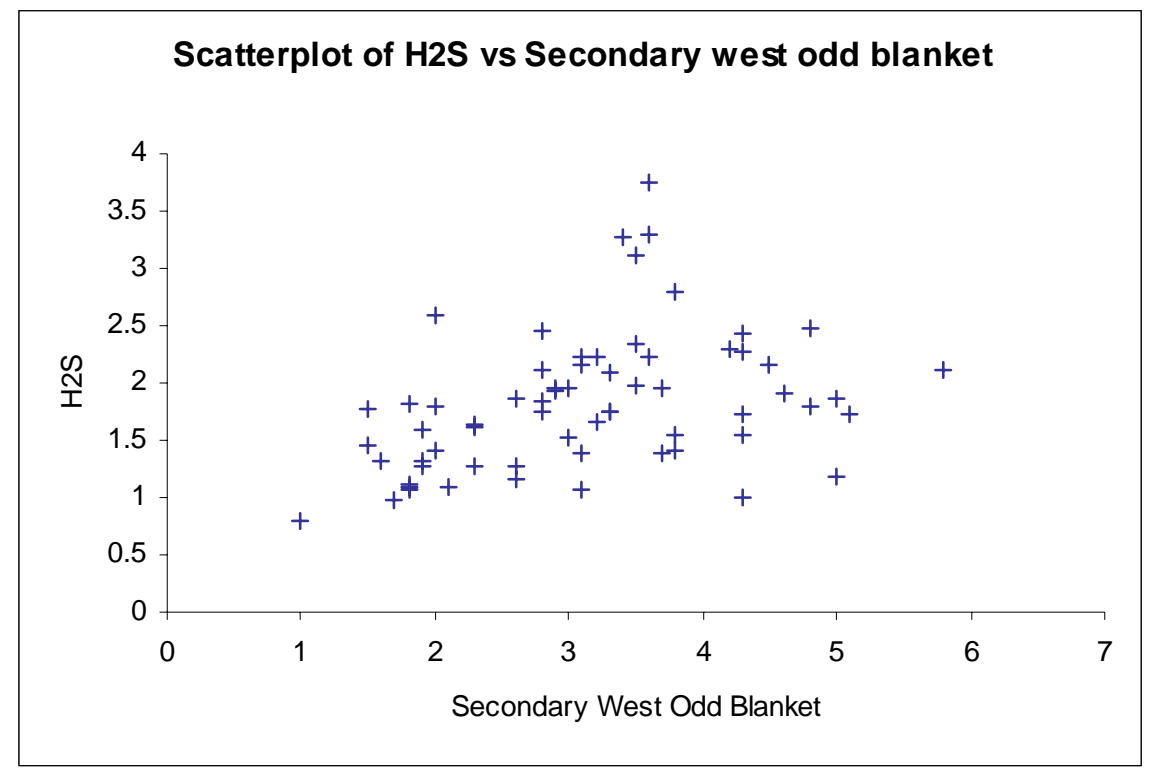

Figure 4-27: Scatterplot total reduced sulfur VS Secondary west odd blanket

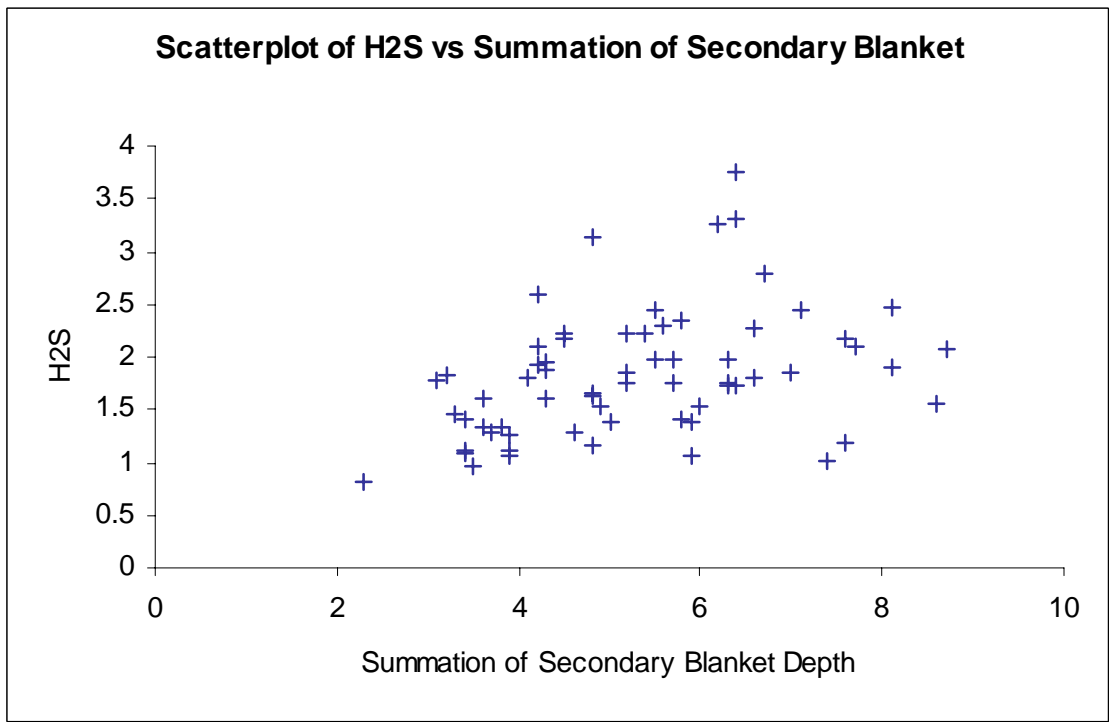

Figure 4-28: Scatterplot total reduced sulfur VS Sum of the secondary blanket 


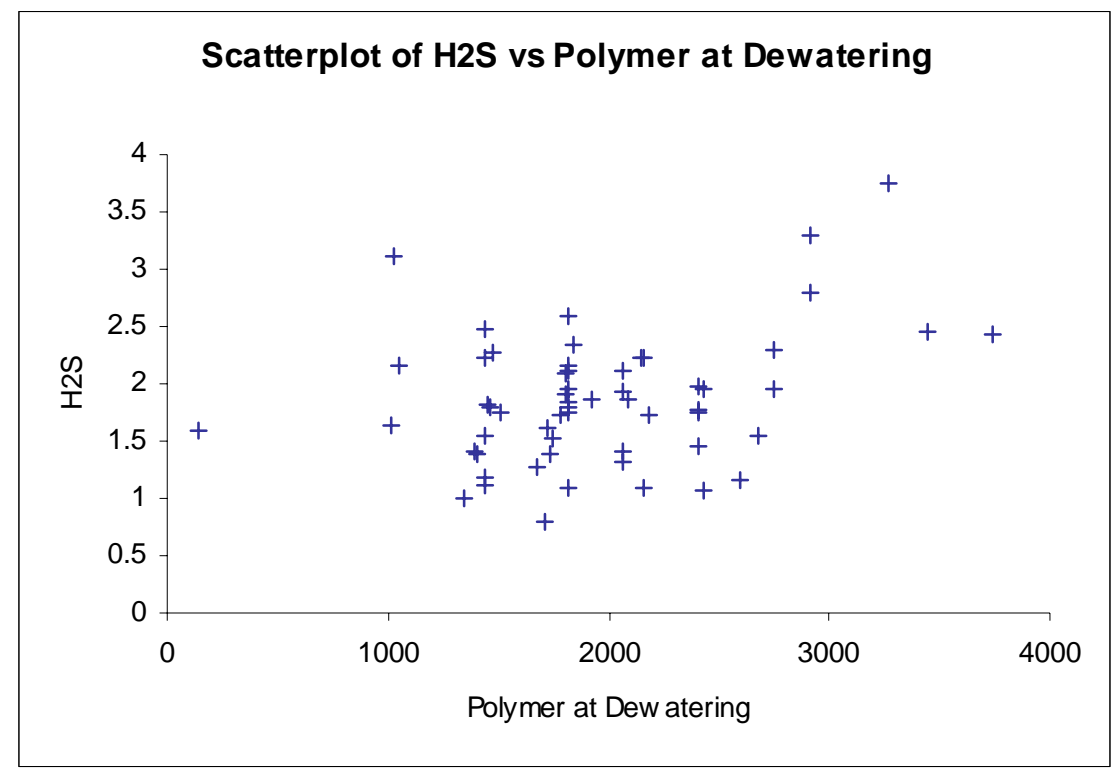

Figure 4-29: Scatterplot total reduced sulfur VS Polymer addition at dewatering

The next step was regression analysis by using multiple regressions. The independents variables having strong correlation with total reduced sulfur in each period of time were selected in multiple regression by the STAT Tool application. In addition, Gabriel, et al. (2006) considered dummy variables and interaction variables can be used to help improve multiple regression models. Therefore, this research will included those techniques in the models as well.

\subsection{Regression Analysis}

The results of correlation analysis in the previous section will be used in this regression analysis. Due to independent variables (predictors or process variables) having strong correlation with total reduced sulfur in this research have more than one variable, it necessary to solve this problem by using suitable regression models. The expectation of 
this analysis is to know which process variables are the main factors in promoting odor level in biosolids after the dewatering process. Since the data collection and analysis was divided into three periods, we have to find the model for each period and then compare each to one another. To use multiple regressions, it is necessary to know the concepts and criteria for selecting which model is the best for this research.

\subsubsection{Overview and Criteria}

Multiple regression is used to forecast the variance of a dependency based on linear combinations, and by establishing that a set of independent variables explains a proportion of the variance in a dependent variable at a significant level (through a significant test of $\mathrm{R}^{2}$ ) (Garson 2006). Since the goal of this research is to find which process variables can be used to explain total reduced sulfur, we define process variables

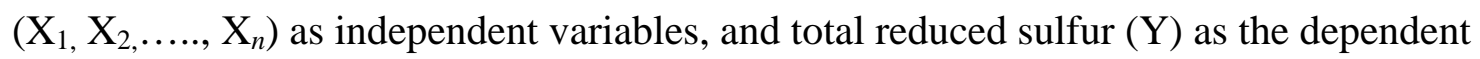
variable. Suppose we have $k$ process variables $\left(\mathrm{X}_{1}, \mathrm{X}_{2}, \ldots ., \mathrm{X}_{k}\right)$ that have strong correlation with total reduced sulfur Y. According to Gabriel, et al. (2006), we can use linear multiple regression to model the relationship between $\mathrm{Y}$ and $k$ independent variables by

$$
Y_{i}=\beta_{0}+\beta_{1} X_{i 1}+\beta_{2} X_{i 2}+\ldots \ldots+\beta_{k} X_{i k}+\varepsilon_{i}
$$

Where;

$$
\begin{aligned}
& \mathrm{Y}_{i}=\text { value of dependent variable (total reduced sulfur) for } i \text { th data point, } i=1, \ldots, n \\
& \mathrm{X}_{i j}=\text { value of } j \text { th independent variable (process variables) for } i \text { th data point, } \\
& \qquad i=1, \ldots, n, j=1, \ldots, k \\
& \beta_{0}=\text { the constant or intercept } \\
& \beta_{j}=\text { regression coefficients of independent variable } j, j=1, \ldots, k
\end{aligned}
$$


$\varepsilon_{i}=$ the error reflected in the residuals

Choosing the best regression equations having different sets of independent variables, we usually want to select the equation with the lowest value of standard error of estimate (SEE) (Winston 2004). Vilalai (2003) and Gabriel, et al. (2006) suggest that adjusted $\mathrm{R}^{2}$, the correct sign of each independent's coefficient, and the $p$-value are three parameters that can be used to identify an appropriate equation in a regression model. In this research will use adjusted $\mathrm{R}^{2}$, significance level (p-value) of variables’ coefficient, and correct sign of independent variables' coefficient to identify which regression model is the best for each period. Additionally, the present research has shown the other criteria in statistical models.

1. Adjusted $\mathrm{R}^{2}$ is an adjustment for the fact that when one has large number of independent, it is possible that $\mathrm{R}^{2}$ will become artificially high simply because some independents' chance variations “explain” small parts of the variance of the dependent (Garson 2006). Normally, when there are as many independent variables as cases in the sample, $R^{2}$ will be close to 1.0 . But, incase $R^{2}$ is lower and we try to increase $R^{2}$ by adding another variable, it will be inappropriate unless variables are added to the equation for sound theoretical reason. For this issue, the adjusted $\mathrm{R}^{2}$ can be used to explain this situation. Gabriel, et al. (2006) considered the model should achieve a relatively high adjusted $\mathrm{R}^{2}$ value. This is one of the criteria that this research uses to select the best model in each period.

2. Significance level ( $p$-value) of variables' coefficient $P$-value is the smallest level of significance at which $H_{0}$ would be rejected when a specified test procedure is used on a given data set. Traditional levels of significance are 
0.10, 0.05, and 0.01 (Devore 1987). In this research, we focus on the significance level of 0.05. But in the practical work, an open system at wastewater treatment plant is significantly different from a close system in laboratory. Therefore, a significance level of $0.1-0.3$ is acceptable for this research.

\section{Correct sign of variables' coefficient}

This is another important parameter which can be used to explain the effect of each independent variable in the model. The positive sign of the coefficient means that if that variable is increased, it will make the total reduced sulfur increases as well. A negative sign for the coefficient means that if that variable increases, it can help decrease total reduced sulfur level in biosolids.

4. F- test is the test statistic to test hypothesis. The followings are overall hypothesis:

$$
\begin{aligned}
& H_{0} \quad: \beta_{1}=\beta_{2}=\ldots \beta_{k}=0 \\
& H_{a} \quad: \text { at least one } \beta_{j} \neq 0
\end{aligned}
$$

The $F$ statistic is the ratio of the explained variability (as reflected by $\mathrm{R}^{2}$ ) and the unexplained variability (as reflected by $1-\mathrm{R}^{2}$ ), each divided by the corresponding degree of freedom. From the definition, if we fail to reject $H_{0}$ that means there is no evidence that any of the independent variables are linearly associated with the dependent variable, and if we reject $H_{0}$ that means at least one of the independent variables is linearly associate with the dependent variable.

\subsubsection{Dummy Variable}

A dummy variable (D), called a dummy-variable regressor or an indicator variable, is a numerical variable used in regression analysis to represent subgroups of the sample in the 
research. In the simplest case, we use a 0 or a 1 for the value of the dummy variable. We give a value of 0 if the condition is not met or 1 if the condition is met. The dummyvariable $\mathrm{D}$ can be explained for the observation $i$ :

$$
D_{i}= \begin{cases}1 & \text { if condition is present } \\ 0 & \text { otherwise }\end{cases}
$$

One of the limitations of multiple regression analysis is that it accommodates only quantitative explanatory variables. We expect that dummy-variable can be used to incorporate qualitative explanatory variables into a linear model, substantially expanding the range of application of regression analysis, and can be used to improve our multiple regression models in each period (Gabriel, et al. 2006). We can modify Equation 5 by adding dummy variables:

$$
\mathrm{Y}_{i}=\beta_{0}+\beta_{1} \mathrm{X}_{1 i}+\beta_{2} \mathrm{X}_{2 i}+\gamma \mathrm{D}_{i} \ldots \ldots+\beta_{k} \mathrm{X}_{k i}
$$

Where;

$$
\gamma=\text { dummy’s coefficient }
$$

With a dummy variable presents in Eq. (5), the interceptor will be change as follows:

$$
\begin{cases}\beta_{0}+\gamma & \text { if condition is present } \\ \beta_{0} & \text { otherwise }\end{cases}
$$

Since this research has many independent variables, we will use the variables that are expected to increase total reduced sulfur to be as dummy variable. We can set up the following dummy variables as:

- D secondary west odd blanket $=1$ if blanket level height $>1.8 \mathrm{ft}$; 0 otherwise. Because the secondary west odd blanket has the strongest correlation with total reduced sulfur, it is essential to know what the height of the blanket level is that affects total reduced sulfur level. This value is taken from scatter plot between the secondary west 
odd blanket and total reduced sulfur from February to August 2006 which shows that after this point odor level will increase. The value was selected from the $20^{\text {th }}$ percentile of secondary west odd data. In addition, DCWASA tries to keep the target of blanket level of both sides at 1.8 -2.0 ft (DCWASA 2006). The scatter plot and percentile of this dummy-variable can be seen in Appendix A.

- $\mathrm{D}$ sum of secondary blanket $=1$ if blanket level height $>3.8 \mathrm{ft}$; 0 otherwise. This dummy-variable is expected to increase biosolids' odor (Vilalai 2003). This number is selected from scatter plot by considering that this level of summation of two sides will promote total reduced sulfur level. This value is also taken from the $20^{\text {th }}$ percentile of the sum of secondary blanket. The scatter plot and percentile can be seen in Appendix A.

- D polymer at dewatering $=1$ if polymer added $>$ 2,760 lb; 0 otherwise. According to Vilalai (2003), polymer can cause biosolids’ odor to increase. This research found that this variable has a correlation with total reduced sulfur in the third period. It would be useful to know how much of this polymer operators could add without causing any odor after dewatering. This value is also taken from scatter plot that at this amount will cause more odors, and selected from the $75^{\text {th }}$ percentile of polymer addition at dewatering. The scatter plot and percentile of this dummy variable can be also seen in Appendix A.

All of the above dummy variables are expected to have the positive signs when they are in the model.

\subsubsection{Interaction Variable}

An interaction variable is the outcome of two or more variables multiplying together, but this relationship implies neither causation nor correlation. In case where one variable that 
has a positive sign with total reduced sulfur but cannot be used alone in the model, unless it is multiplied but if it multiply with another variable having a positive sign, then they can be used to improve the model. Then Eq. (4) can be modified to the following form:

$$
\mathrm{Y}_{i}=\beta_{0}+\beta_{1} \mathrm{X}_{1 i}+\beta_{2} \mathrm{X}_{2 i}+\beta_{3} \mathrm{X}_{1} \mathrm{X}_{2} \ldots \ldots+\beta_{k} \mathrm{X}_{k i}
$$

The followings are interaction variables:

- Sum of secondary blanket * sum of RAS

- Sum of TPS\&TWAS * polymer at dewatering

- Sum of secondary blanket * polymer at DAF

All of the above interaction variables are expected increase amount of total reduced sulfur in biosolids if they multiplied by each other. For instance, if the sum of secondary blanket from east side and west side are high and the sum of RAS from east and west are also high, they can increase the odor level. All the interaction variables above, we will have positive signs when they are in the model.

\subsection{Multiple Regression Analysis}

As this research has data from three time periods, February-August 2006, February-April 2006, and May-August 2006, the followings are the best result of multiple regression models including dummy variable and interaction variable in each period. The fact that each period has many models to select, we will use the criteria discussed above to classify the best model for each period. In addition, to review another model in each period, please see in Appendix B, Appendix C, and Appendix D respectively. To get the best multiple regression model, this research uses STAT Tool application to analyze these data. After comparing each model, we will get the best regression model for this 
research as shown in Section 4.4. The following diagram in Figure 4-30 explains the procedure to get the best model for this research: 


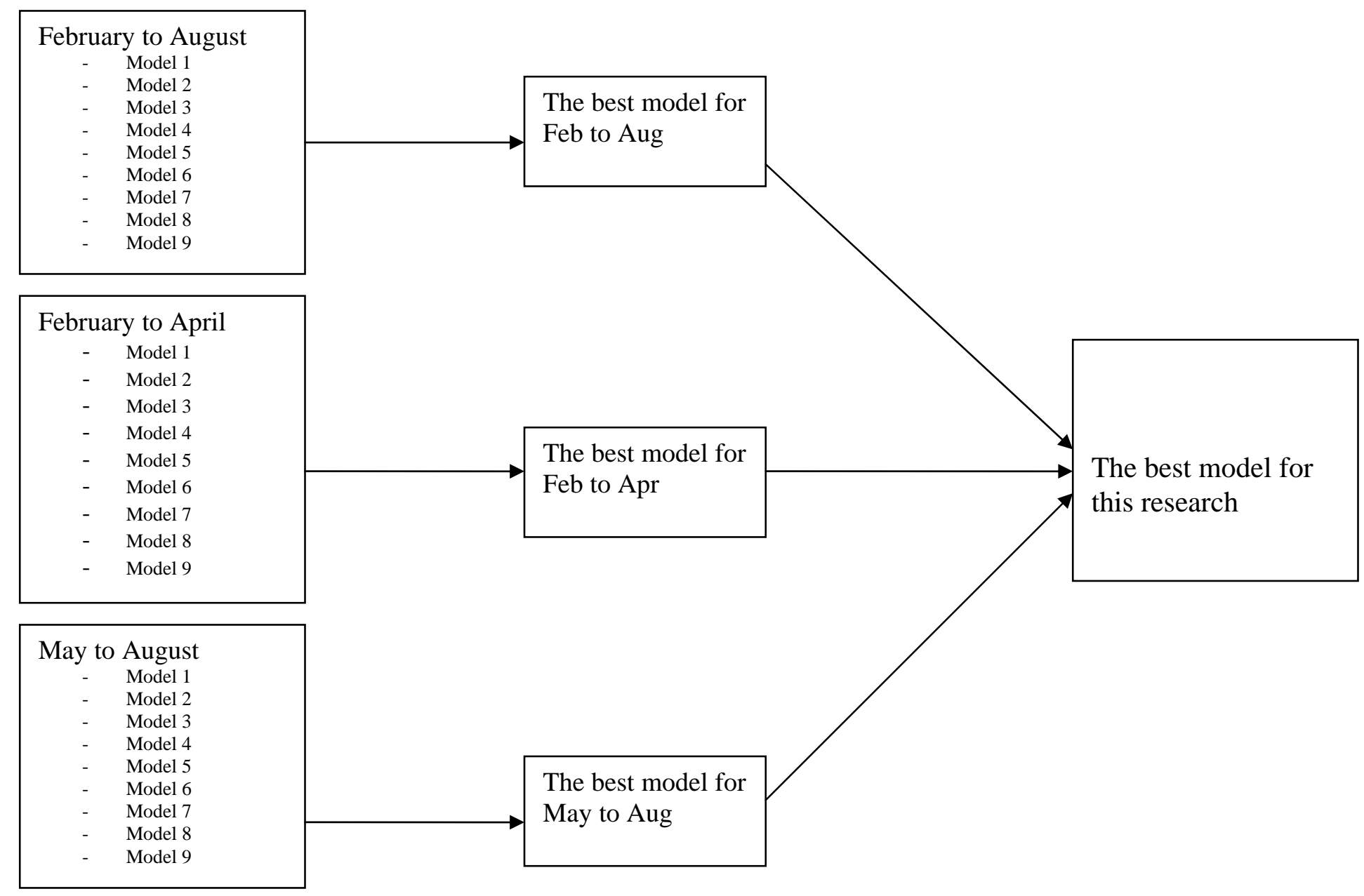

Figure 4-30: Diagram of procedure to get the best model in this research 
4.3.1 Multiple regression model for the February to August 2006

For this period, we found the following result as shown in Table 4-5 to be the best model for this period. To compare with another model in this period, please see in Appendix B. In Table 4-5, we can transform to the following equation:

$$
\begin{aligned}
& \text { Y }=0.852+0.409 \mathrm{X}_{1}+0.182 \mathrm{X}_{2}+0.170 \mathrm{X}_{3} \\
& \qquad \begin{array}{r}
\mathrm{Y}=\text { Total reduced sulfur } \\
\mathrm{X}_{1}=\text { D secondary west odd blanket }>1.8 \mathrm{ft} . \\
\mathrm{X}_{2}=\text { D polymer at dewatering }>2760 \mathrm{lbs} / \mathrm{D} . \\
\mathrm{X}_{3}=\text { Secondary west odd blanket depth }
\end{array}
\end{aligned}
$$

From Table 4-5, that model can reject the null hypothesis and that the $p$-value of the overall model in ANOVA is 0.0001 which is less than 0.05 that means the overall of this model is statistically significant. The adjusted $\mathrm{R}^{2}$ of this model is 0.2038 which is pretty low because there is some issue about calibration from February to April 2006. The $\mathrm{R}^{2}$ of this model is 0.2337 which means about 23 percent of the variance in total reduced sulfur is explained by secondary west odd blanket variable, D secondary west odd blanket $>1.8 \mathrm{ft}$., and D polymer at dewatering $>2760 \mathrm{lbs} / \mathrm{D}$. The $p$-value of each variable, the secondary west odd blanket having a $p$-value of 0.02 and the $\mathrm{D}$ secondary west odd blanket $>1.8 \mathrm{ft}$. having a $p$-value of 0.05 (which are lower than 0.05 ), and the D polymer at dewatering $>2760 \mathrm{lbs} / \mathrm{D}$ having a $p$-value of 0.186 (which is higher than 0.1 
but lower than 0.2) but are acceptable for practical work. For the sign of all variables' coefficient, they follow the correlation analysis result in Section 4.1.3. As the correlation analysis shows that the secondary west odd blanket has the strongest correlation with total reduced sulfur, and from the model the sign is positive, it confirms that when the higher blanket level of secondary west odd is present, the more total reduced sulfur is produced (Sekyiamah 2005). According this period includes dummy variable in the model, and it was found that if the blanket level of secondary west odd blanket is higher than $1.8 \mathrm{ft}$., it promote total reduced sulfur level in biosolids, and the sign of the variable's coefficient is positive. Another dummy variable is the polymer at dewatering process $>2760 \mathrm{lbs} / \mathrm{D}$ which means if the operators add polymer at dewatering more than $2760 \mathrm{lb}$, it will promote odor level in biosolids. The purpose of adding polymer at dewatering is to help centrifuges remove water easily from biosolids. However the amounts of polymer that are added depend on the decision of operators so this variable can be artificial. However, it can help DCWASA to decrease odor level in biosolids but allows dewatering to be performed at the necessary level. In addition, it can help DCWASA to save the cost of polymer addition at dewatering if this number can be used in the model. The comparison between the predicted value of total reduced sulfur and the monitored data can be seen in Figure4-31 and Table 4-6. 
Table 4-5: Regression result for the February to August 2006

\begin{tabular}{|c|c|c|c|c|c|c|}
\hline Summary & $\begin{array}{l}\text { Multiple } \\
\quad \text { R } \\
0.4834\end{array}$ & $\begin{array}{c}\text { R-Square } \\
0.2337\end{array}$ & $\begin{array}{c}\text { Adjusted } \\
\text { R-Square } \\
0.2038\end{array}$ & $\begin{array}{c}\text { StErr of } \\
\text { Estimate } \\
0.530157096\end{array}$ & & \\
\hline $\begin{array}{l}\text { ANOVA Table } \\
\text { Explained } \\
\text { Unexplained }\end{array}$ & $\begin{array}{c}\text { Degrees of } \\
\text { Freedom } \\
3 \\
77\end{array}$ & $\begin{array}{c}\begin{array}{c}\text { Sum of } \\
\text { Squares }\end{array} \\
6.599526249 \\
21.64212404\end{array}$ & $\begin{array}{c}\text { Mean of } \\
\text { Squares } \\
2.199842083 \\
0.281066546\end{array}$ & $\begin{array}{l}\text { F-Ratio } \\
7.8268\end{array}$ & $\begin{array}{l}p \text {-Value } \\
0.0001\end{array}$ & \\
\hline & Coefficient & Standard & t-Value & p-Value & \multicolumn{2}{|c|}{ Confidence Interval 95\% } \\
\hline Regression Table & & Error & & & Lower & Upper \\
\hline Constant & 0.851639371 & 0.200333578 & 4.2511 & $<0.0001$ & 0.452724254 & 1.250554488 \\
\hline D secondary west odd blanket $>1.8 \mathrm{ft}$ & 0.409425821 & 0.206062594 & 1.9869 & 0.0505 & -0.000897224 & 0.819748866 \\
\hline D polymer at dewatering $>2760 \mathrm{lbs} / \mathrm{D}$ & 0.182400111 & 0.136730007 & 1.3340 & 0.1861 & -0.089864116 & 0.454664339 \\
\hline Secondary west odd blanket & 0.170364219 & 0.072445612 & 2.3516 & 0.0213 & 0.026106576 & 0.314621861 \\
\hline
\end{tabular}




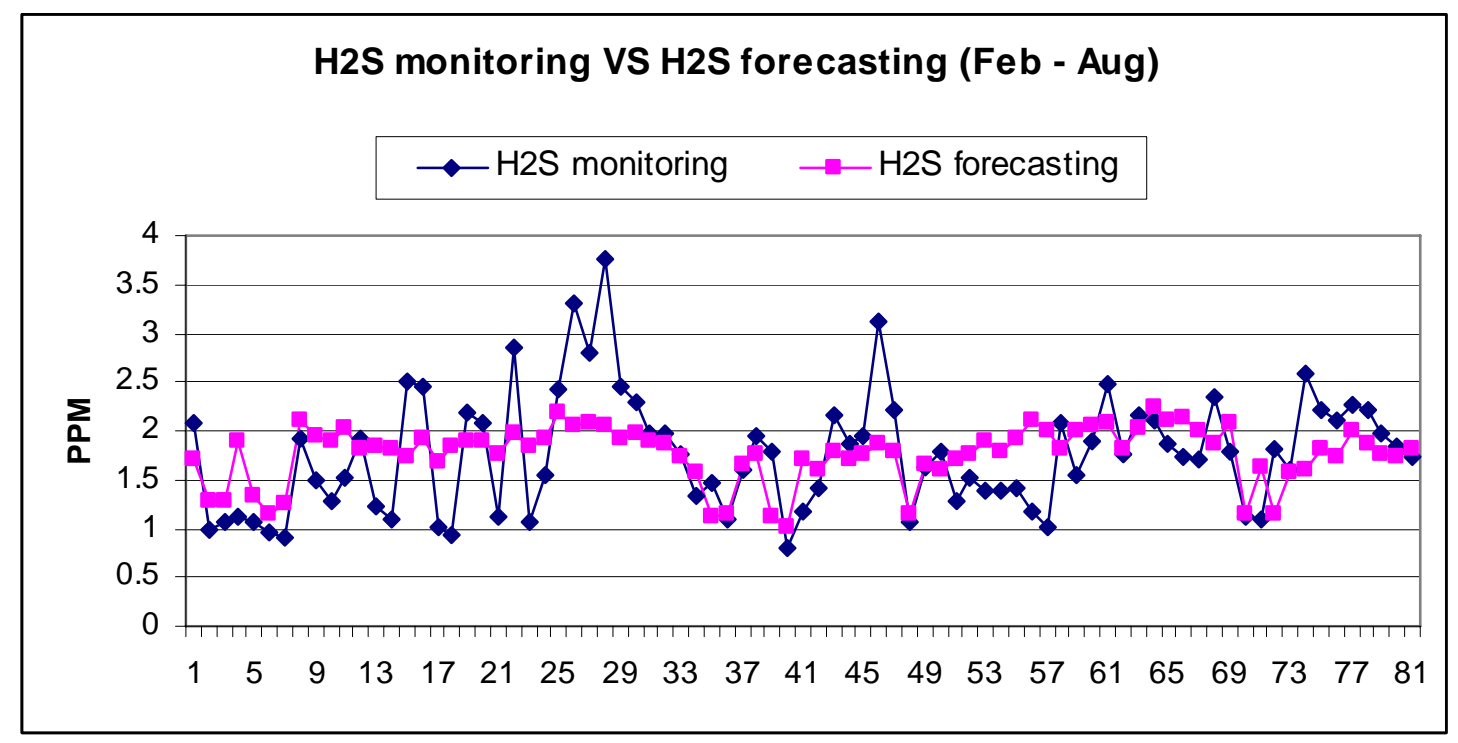

Figure 4-31: Total reduced sulfur monitoring VS Total reduced sulfur forecasting

Table 4-6: Summary of monitored data and forecasted data in the Feb to Aug 2006

\begin{tabular}{|c|c|c|}
\hline & Actual H2S & Forecasting \\
\hline Variable Summary & & \\
\hline Mean & 1.7626 & 1.7626 \\
Variance & 0.3530 & 0.0825 \\
Std. Dev. & 0.5942 & 0.2872 \\
Skewness & 0.7192 & -1.0162 \\
Kurtosis & 3.6946 & 3.4490 \\
Median & 1.7583 & 1.8233 \\
Mean Abs. Dev. & 0.4704 & 0.2135 \\
Minimum & 0.8067 & 1.0220 \\
Maximum & 3.7500 & 2.2492 \\
Range & 2.9433 & 1.2272 \\
Count & 81 & 81 \\
Sum & 142.7687 & 142.7687 \\
\hline
\end{tabular}




\subsubsection{Multiple regression model for February to April 2006}

In this period, we have 44 data points for monitored data. We have limiting data of chemical addition. The Department of Wastewater Treatment began setting up the new data recording system in the middle of April for collecting chemical addition data, especially polymer addition. Therefore, some data are still missing. Another issue during this period is that monitors were not calibrated properly which could affect in data analysis. For this period, even though we used dummy variable and interaction variable to improve the model, we didn't get the good result from both techniques. The following is the result from Stat Tool analysis and can be seen in Table 4-7. To compare it with another model, please see Appendix C. Data from Table 4-7 can be transformed to the following equation:

$$
\begin{aligned}
& \text { Y }=0.2896+0.491 \mathrm{X}_{1} \\
& \text { Where; } \\
& \qquad \mathrm{Y}=\text { Total reduced sulfur } \\
& \qquad \mathrm{X}_{1}=\text { Secondary west odd blanket depth }
\end{aligned}
$$

The above equation is the best model for this period. We found that only the secondary west odd blanket variable is the significant source for total reduced sulfur. From Table 4-7, the adjusted $\mathrm{R}^{2}$ is 0.2582 . The $\mathrm{R}^{2}$ is 0.295 which means about 30 percent of variance in total reduced sulfur explained by secondary west odd blanket. The $p$-value of the overall model in ANOVA about 0.01 which is less than 0.05 and means this model is statistically significant. The $p$-value of the secondary west odd blanket is 0.01 which 
means the secondary west odd has a significant relationship with total reduced sulfur, and the sign of the variable' s coefficient is still positive. Therefore, the higher the blanket level of the secondary west odd blanket, the more total reduced sulfur is produced. The graph and table of total reduced sulfur from monitored data and forecasted data can be seen in Figure 4-32 and Table 4-8. 
Table 4-7: Regression result for the February to April 2006

\begin{tabular}{|c|c|c|c|c|c|c|}
\hline Summary & $\begin{array}{l}\text { Multiple } \\
\quad \mathbf{R} \\
0.5434\end{array}$ & $\begin{array}{l}\text { R-Square } \\
0.2953\end{array}$ & $\begin{array}{l}\text { Adjusted } \\
\text { R-Square } \\
0.2582\end{array}$ & $\begin{array}{c}\text { StErr of } \\
\text { Estimate } \\
0.525426953\end{array}$ & & \\
\hline $\begin{array}{l}\text { ANOVA Table } \\
\text { Explained } \\
\text { Unexplained }\end{array}$ & $\begin{array}{c}\text { Degrees of } \\
\text { Freedom } \\
1 \\
19\end{array}$ & $\begin{array}{c}\text { Sum of } \\
\text { Squares } \\
2.198260417 \\
5.245396174\end{array}$ & $\begin{array}{c}\text { Mean of } \\
\text { Squares } \\
2.198260417 \\
0.276073483\end{array}$ & $\begin{array}{l}\text { F-Ratio } \\
7.9626\end{array}$ & $\begin{array}{l}p \text {-Value } \\
0.0109\end{array}$ & \\
\hline $\begin{array}{l}\text { Regression Table } \\
\text { Constant } \\
\text { Secondary west odd blanket dept }\end{array}$ & $\begin{array}{c}\text { Coefficient } \\
0.289619753 \\
0.490648196\end{array}$ & $\begin{array}{c}\text { Standard } \\
\text { Error }\end{array}$ & $\begin{array}{l}\text { t-Value } \\
\\
0.6307 \\
2.8218\end{array}$ & $\begin{array}{l}p \text {-Value } \\
0.5357 \\
0.0109\end{array}$ & $\begin{array}{c}\begin{array}{c}\text { Confidenc } \\
\text { Lower }\end{array} \\
-0.671444102 \\
0.126718744\end{array}$ & $\begin{array}{c}\text { terval } 95 \% \\
\text { Upper } \\
1.250683608 \\
0.854577648\end{array}$ \\
\hline
\end{tabular}




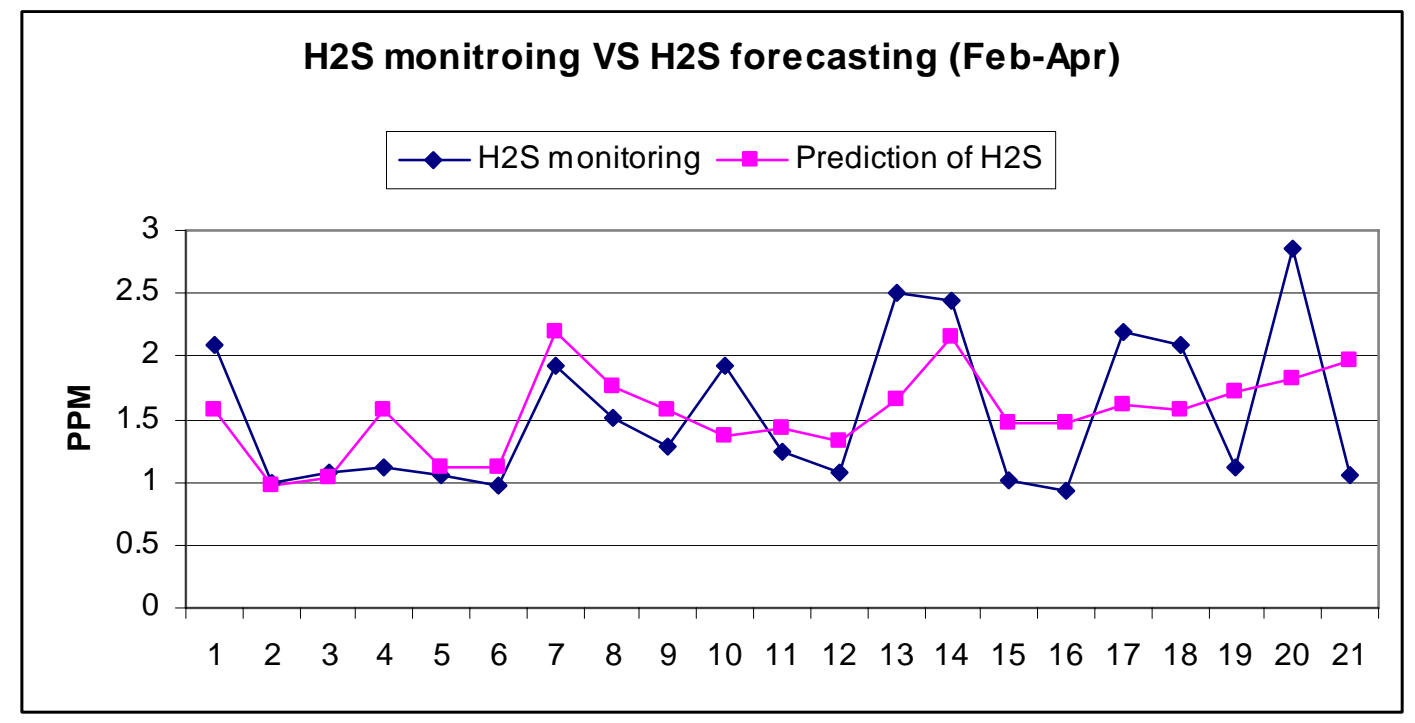

Figure 4-32: Total reduced sulfur monitoring VS Total reduced sulfur forecasting

Table 4-8: Summary of monitored data and forecasted data in the Feb to Apr 2006

\begin{tabular}{|c|c|c|}
\hline Variable Summary & Actual H2S & Forecasting \\
\hline Mean & 1.5443 & 1.5443 \\
Variance & 0.3722 & 0.1099 \\
Std. Dev. & 0.6101 & 0.3315 \\
Skewness & 0.7676 & 0.1950 \\
Kurtosis & 2.1620 & 2.8845 \\
Median & 1.2333 & 1.5653 \\
Mean Abs. Dev. & 0.5373 & 0.2483 \\
Minimum & 0.9383 & 0.9765 \\
Maximum & 2.8458 & 2.2031 \\
Range & 1.9075 & 1.2266 \\
Count & 21 & 21 \\
Sum & 32.4298 & 32.4298 \\
\hline
\end{tabular}




\subsubsection{Multiple regression model for May to August 2006}

For this period, both monitored devices were calibrated, and all chemical additions were recorded in order. Therefore, we expect to get the a good model and good result from this period. The following is the best model for this period. To compare this one with another model from this period, please see in Appendix D. Using data from Table 4-9, we can make the following equation:

$$
\begin{aligned}
& \text { Y }=1.1098+0.3664 \mathrm{X}_{1}+1.1037 \mathrm{X}_{2}+0.101 \mathrm{X}_{3} \\
& \text { Where; } \\
& \qquad \begin{array}{l}
\mathrm{Y}=\text { Total reduced sulfur } \\
\mathrm{X}_{1}=\text { D secondary west odd blanket }>1.8 \mathrm{ft} . \\
\mathrm{X}_{2}=\text { D polymer at dewatering }>2,760 \mathrm{lbs} \text {. } \\
\mathrm{X}_{3}=\text { Secondary west odd blanket depth }
\end{array}
\end{aligned}
$$

From the equation above and the result from Table 4-9, the adjusted $\mathrm{R}^{2}$ is 0.389 . The $\mathrm{R}^{2}$ is 0.418 which means about 42 percent of variance in total reduced sulfur explained by the secondary west odd blanket, D secondary west odd $>1.8 \mathrm{ft}$, and D polymer at dewatering $>2,760$ lbs. The $p$-value of the overall model in ANOVA is less than $<0.0001$ which means this model is statistically significant. The $p$-value of the $\mathrm{D}$ polymer at dewatering $>2760$ is $<0.0001$ which is less than 0.05 and very significant. The $p$-value of the $\mathrm{D}$ secondary west odd blanket is 0.08 which is lower than 0.1 and still significant. But the secondary west odd blanket has a $p$-value $=0.136$ which is higher 
than 0.1 . However, the $p$-value of secondary west odd blanket is still lower than 0.15 and can be acceptable for the practical work. The signs of all the variable’s coefficients are positive which means they have the potential to promote total reduced sulfur level in biosolids. Again the independent variables of this model are similar to those in the model for February to August 2006. The graph and table showing the relation ship between total reduced sulfur monitoring and total reduced sulfur forecasting and the summary value can be seen in Figure 4-33 and Table 4-10, respectively. In Section 4.4, we will compare all three models and select the best model for this research.

According to Figure 4-33, at the point 28 has monitoring data higher than the forecasting data because centrifuges were turned off on the day before and there were some old biosolids left in centrifuges and in conveyor for 10 hours, and they became septic in conveyor. Then after the operator turned on the centrifuges, the odor of the old biosolids can affect the monitoring data. But for the other points, the monitoring and forecasting are slightly different. 
Table 4-9: Regression result for the May to August 2006

\begin{tabular}{|c|c|c|c|c|c|c|}
\hline Summary & $\begin{array}{c}\text { Multiple } \\
\quad \mathbf{R} \\
0.6464\end{array}$ & $\begin{array}{c}\text { R-Square } \\
0.4179\end{array}$ & $\begin{array}{c}\text { Adjusted } \\
\text { R-Square } \\
0.3892\end{array}$ & $\begin{array}{c}\text { StErr of } \\
\text { Estimate } \\
0.46641899\end{array}$ & & \\
\hline $\begin{array}{l}\text { ANOVA Table } \\
\text { Explained } \\
\text { Unexplained }\end{array}$ & $\begin{array}{c}\text { Degrees of } \\
\text { Freedom } \\
3 \\
61\end{array}$ & $\begin{array}{c}\text { Sum of } \\
\text { Squares } \\
9.525825092 \\
13.27034711\end{array}$ & $\begin{array}{c}\text { Mean of } \\
\text { Squares } \\
3.175275031 \\
0.217546674\end{array}$ & $\begin{array}{c}\text { F-Ratio } \\
14.5958\end{array}$ & $\begin{array}{c}\text { p-Value } \\
<0.0001\end{array}$ & \\
\hline $\begin{array}{l}\text { Regression Table } \\
\text { Constant } \\
\text { D secondary west odd blanket }>1.8 \\
\text { D polymer at dewatering }>2760 \\
\text { Secondary west odd blanket } \\
\end{array}$ & \begin{tabular}{c|} 
Coefficient \\
1.109769043 \\
0.36646254 \\
1.103733584 \\
0.100953453 \\
\end{tabular} & $\begin{array}{c}\text { Standard } \\
\text { Error } \\
0.189169221 \\
0.204892671 \\
0.219314268 \\
0.066888178 \\
\end{array}$ & $\begin{array}{l}\mathrm{t}-\text { Value } \\
5.8665 \\
1.7886 \\
5.0327 \\
1.5093 \\
\end{array}$ & $\begin{array}{c}\text { p-Value } \\
<0.0001 \\
0.0787 \\
<0.0001 \\
0.1364 \\
\end{array}$ & $\begin{array}{c}\text { Confiden } \\
\text { Lower } \\
0.731501808 \\
-0.043245677 \\
0.665187601 \\
-0.032797725 \\
\end{array}$ & $\begin{array}{c}\text { terval } 95 \% \\
\text { Upper } \\
1.488036278 \\
0.776170758 \\
1.542279567 \\
0.234704631 \\
\end{array}$ \\
\hline
\end{tabular}




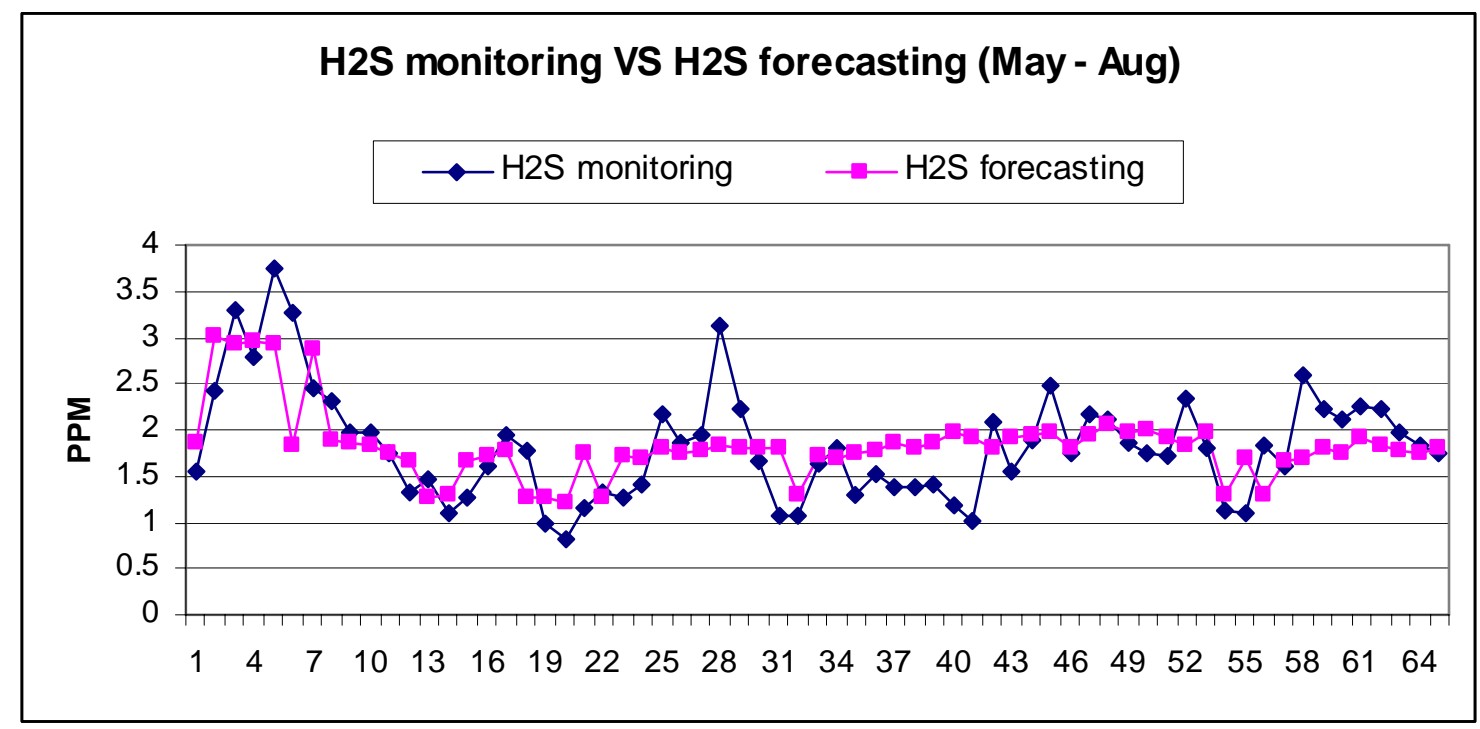

Figure 4-33: Total reduced sulfur monitoring VS Total reduced sulfur forecasting

Table 4-10: Summary of monitored data and forecasted data in the May to Aug 2006

\begin{tabular}{|c|c|c|}
\hline & Actual H2S & Forecasting \\
\hline Variable Summary & & \\
\hline Mean & 1.8265 & 1.8265 \\
Variance & 0.3562 & 0.1488 \\
Std. Dev. & 0.5968 & 0.3858 \\
Skewness & 0.9236 & 1.5460 \\
Kurtosis & 4.1800 & 6.6681 \\
Median & 1.7771 & 1.7892 \\
Mean Abs. Dev. & 0.4511 & 0.2257 \\
Minimum & 0.8067 & 1.2107 \\
Maximum & 3.7500 & 3.0141 \\
Range & 2.9433 & 1.8033 \\
Count & 65 & 65 \\
Sum & 118.7196 & 118.7196 \\
\hline
\end{tabular}




\subsection{Final Multiple Regression Model}

After getting the best model for each period, next we will compare those models. Table 4-11 compares the properties of each model in order to determine which will be selected to be the best for this research.

To compare between two models or more models, adjusted $\mathrm{R}^{2}$, significance level ( $p$-value) of variables' coefficient, correct sign of independent variables' coefficient, and standard error of estimate (SEE) will be used. Adjusted $\mathrm{R}^{2}$, significance level ( $p$-value) of variables’ coefficient, and correct sign of independent variables’ coefficient were explained previously in Section 4.2.1. In addition, adjusted $\mathrm{R}^{2}$ is used as a conservative reduction to $\mathrm{R}^{2}$ to penalize for adding variables and is required when comparing models with different number of independent variables (Garson 2006). According to Achen (1982), $\mathrm{R}^{2}$ cannot be compared between samples due to differences in variances of the independent and dependent variables. But, for SEE, it is used to estimate the standard error of predicted value so, the good model should have SEE less than the standard deviation of the dependent variable, and the mean of the dependent variable will be greater than 1.96 multiplied by standard error of estimate (Garson 2006). According to Winston (2004), the best regression model has the lowest value of SEE.

From the above criteria and from Table 4-11, we find the model from the May to August 2006 has an adjusted $\mathrm{R}^{2}=0.3892$ which is higher than the other models. The $p$ value in ANOVA $=<0.0001$ which is the lowest value among these models and confirm that this model is statistically significant. The model from the May to August 2006 has the lowest standard error of estimate (SEE), but it is necessary to consider another factor of SEE in the other models. 
The SEE for the model from the February to Aug 2006 is less than the standard deviation of total reduced sulfur $=0.0641(0.5942-0.53015)$. The SEE of the model from the February to April 2006 is less than the standard deviation of total reduced sulfur = 0.0847 (0.6101-0.5254). And the SEE of the model in the May to August 2006 is less than the standard deviation of total reduced sulfur $=0.1304(0.5968-0.4664)$. Therefore, the SEE of the model from the May to August 2006 is markedly less than the standard deviation of total reduced sulfur. In addition, the followings results show the difference between the mean of total reduced sulfur and 1.96 times the SEE of each model:

$$
\begin{array}{lll}
\text { Feb }- \text { Aug } & =0.7235 & (1.7626-(1.96 * 0.53015)) \\
\text { Feb }- \text { Apr } & =0.5145 & (1.5443-(1.96 * 0.5254)) \\
\text { May }- \text { Aug } & =0.9124 & (1.8265-(1.96 * 0.4664))
\end{array}
$$

These indicate that the mean of total reduced sulfur of the model for the May to August 2006 is greater than 1.96 times SEE.

From all of the above analysis, model in the May to Aug 2006 is the best model for this research. This model will be used in the next chapter to draw conclusions and as a basis for future work. 
Table 4-11 Comparison among the best models of each period

\begin{tabular}{|c|c|c|c|c|c|c|c|c|c|}
\hline \multirow{2}{*}{$\begin{array}{l}\text { Model/ } \\
\text { Period }\end{array}$} & \multirow{2}{*}{$\begin{array}{c}\text { Independent } \\
\text { variables }\end{array}$} & \multirow{2}{*}{$\begin{array}{c}\text { Standard } \\
\text { deviation of } \\
\text { Total reduced } \\
\text { sulfur }\end{array}$} & \multirow{2}{*}{$\begin{array}{c}\text { Mean of } \\
\text { Total } \\
\text { reduced } \\
\text { sulfur }\end{array}$} & \multirow[t]{2}{*}{$\mathrm{R}^{2}$} & \multirow{2}{*}{$\begin{array}{c}\text { Adjusted } \\
\mathrm{R}^{2}\end{array}$} & \multicolumn{2}{|c|}{ ANOVA } & \multirow{2}{*}{$\begin{array}{c}p \text {-value of } \\
\text { each } \\
\text { variable }\end{array}$} & \multirow{2}{*}{$\begin{array}{r}\text { Standard } \\
\text { error of } \\
\text { estimate } \\
\text { (SEE) }\end{array}$} \\
\hline & & & & & & F-test & $p$-value & & \\
\hline Feb - Aug & $\begin{array}{l}\text {-D secondary west odd blanket }>1.8 \\
\text {-D polymer at dewatering }>2670 \\
\text {-Secondary west odd blanket }\end{array}$ & 0.5942 & 1.7626 & 0.2337 & 0.2038 & 7.8268 & 0.0001 & $\begin{array}{l}0.0505 \\
0.1861 \\
0.0213\end{array}$ & 0.53015 \\
\hline Feb - Apr & -Secondary west odd blanket & 0.6101 & 1.5443 & 0.2953 & 0.2582 & 7.9626 & 0.0109 & 0.0109 & 0.5254 \\
\hline May - Aug & $\begin{array}{l}\text {-D secondary west odd blanket>1.8 } \\
\text {-D polymer at dewatering }>2670 \\
\text {-Secondary west odd blanket }\end{array}$ & 0.5968 & 1.8265 & 0.4179 & 0.3892 & 14.5958 & $<0.0001$ & $\begin{array}{l}0.0787 \\
<0.0001 \\
0.1364\end{array}$ & 0.4664 \\
\hline
\end{tabular}




\section{Chapter 5: Conclusions and Future Research}

This chapter draws conclusions from the analysis of Chapter 4, and discussed future work.

\subsection{Best model for this research and DCWASA}

The model of May - Aug including the secondary west odd blanket, D secondary west odd $>1.8 \mathrm{ft}$, and D polymer at dewatering $>2760 \mathrm{lbs}$ appears to be the best model from this research. The multiple regression equation for this model is:

$$
\begin{aligned}
& \text { Y }=1.1098+0.3664 \mathrm{X}_{1}+1.1037 \mathrm{X}_{2}+0.101 \mathrm{X}_{3} \\
& \text { Where; } \\
& \qquad \mathrm{Y}=\text { Total reduced sulfur } \\
& \qquad \mathrm{X}_{1}=\text { D secondary west odd blanket }>1.8 \mathrm{ft} . \\
& \mathrm{X}_{2}=\text { D polymer at dewatering }>2,760 \mathrm{lbs} \text {. } \\
& \mathrm{X}_{3}=\text { Secondary west odd blanket }
\end{aligned}
$$

(F-test $=14.5958, p$-value $<0.0001$, Adjusted $\mathrm{R}^{2}=0.3892$, Standard Error of estimate $(\mathrm{SEE})=0.466$. Significant Variables are shown below:

Predictor Variable (Independent variables)

D secondary west odd blanket $>1.8 \mathrm{ft}$

D polymer at dewatering $>2,760$

Secondary west odd blanket

\section{Coefficient}

0.3664

1.1037

0.101 p-value

0.0787

$<0.0001$

$0.1364)$ 
- The model is significant with $p$-value $<0.0001$, and accounts for about 42 percent of total reduced sulfur variance. As $\mathrm{R}^{2}$ increases the SEE decreases so, a better fit leads to less estimation error.

- All coefficients' sign in this model are positive which means if the independent variables increase, total reduced sulfur will increases as well. The regression coefficient is the average amount the dependent variable increases when the independent variable increases one unit and other independent variables are held constant. Therefore, the coefficient 0.101 indicates that if secondary west odd blanket variable increases 1 unit, total reduced sulfur increases 0.101 units, when other independent variables are held constant. The coefficient of $\mathrm{D}$ secondary west odd blanket $>1.8 \mathrm{ft}$ is 0.3664 . This means that the secondary west odd blanket is higher than $1.8 \mathrm{ft}$, it will cause total reduced sulfur to increase by 0.3664 units. Like D secondary west odd blanket, the coefficient of D polymer at dewatering process $>2760 \mathrm{lbs}$ is 1.1037 , this means that if polymer at dewatering was added more than $2760 \mathrm{lb} / \mathrm{D}$, it will cause total reduced sulfur to increase by 1.1037 units.

- All three independent variables are statistically significant. We would typically prefer the $p$-value to be less than 0.05 or 0.1 , but secondary west odd blanket has $p$-value 0.136 . However, it is still less than 0.2 , and may be acceptable for practical work.

The model confirms that the secondary west odd blanket is the main variable to promote total reduced sulfur in biosolids after dewatering process (before lime addition), and supports DCWASA’s research by Sekyiamah (2005). According to Sekyiamah (2005), Volatile Sulfur Compounds (VSCs) concentrations at the bottom of the secondary treatment system are markedly dependent on the sludge blanket levels (SBLs), which 
means the higher the SBLs the greater the production of VSCs. In addition, the present model suggests that if the blanket level at the secondary west odd is higher than $1.8 \mathrm{ft}$, it will promote total reduced sulfur in biosolids, which can be seen from the multiple regression equation. DCWASA's target for the secondary blanket level is $1.8-2.0 \mathrm{ft}$, so the model gives the optimal blanket level. Another variable in this model is D polymer at dewatering. The purpose of adding polymer is to hold sludge particle together and increase the performance of the centrifuge for removing water, but this research found that adding polymer at dewatering promotes total reduced sulfur level. According to Vilalai (2003), polymer addition and the dummy variable of polymer at dewatering are expected to increase biosolids odor and should have a positive sign. According to the present model, if operators add more than $2760 \mathrm{lbs} /$ day of polymer, it indicates that the total reduced volatile sulfur is high after dewatering.

\subsection{The Advantage of this Model for DCWASA}

This research found that a secondary west odd blanket, more than $1.8 \mathrm{ft}$, and polymer addition at dewatering process more than $2760 \mathrm{lb}$ /day affect total reduced sulfur. The biosolids manager or all supervisors at DWT can apply this model to control total reduced sulfur before biosolids have been trucked to the field site. For instance, if they found that secondary sedimentation at the west side is higher than $1.8 \mathrm{ft}$ and polymer at dewatering are added more than $2760 \mathrm{lb}$, they can schedule the new routes for trucks to distribute biosolids to the remote field sites or not close to residential areas. However, they have to concern about dewatering performance. Because if they have to decrease amount of polymer at dewatering in order to control odor, it will affect dewatering efficiency. Therefore, it must be investigated further by laboratory experiments, and the 
results compared with this analysis. If the result is higher than $2760 \mathrm{lb} / \mathrm{D}$, this model will be valid. Another benefit for DCWASA is they can save cost for purchase polymer at dewatering. Because if operators allow the blanket level to become high, they have to operate more centrifuges for removing sludge out of the system, and the operators at dewatering process have to add more polymer in order to help centrifuge to remove water. When the sludge in blend tank is high, operators have to operate more centrifuges in order to take sludge out of blend tank to keep the blend ratio good, and they have also added more polymers at dewatering, so it costs more to remove water from biosolids.

\section{$\underline{5.3 \text { Future Work }}$}

This research monitored total reduced sulfur after dewatering process (before lime addition), and identified process parameters promoting total reduced sulfur in biosolids. The next research will use the information from this study to compare the monitored data after lime addition process. DCWASA will transfer biosolids after lime addition from the bunker, which is the old storage of biosolids after lime addition, to Silo storage which is the newest technology. Therefore, if we know the level of total reduced sulfur at the outlet to trucks before distributing to field sites, we can compare these levels with those before lime addition. In addition, we can use this information to support other research studying odor at field sites. Another confirmation would be to study the temperature of biosolids before and after lime addition, and use statistical method to find out the correlation between temperature of biosolids before and after lime addition and total reduced sulfur before and after lime addition. These further studying will help DCWASA improve the efficiency of biosolids management and performance of wastewater treatment. 


\section{Appendix A}

1. D secondary west odd blanket $>1.8 \mathrm{ft}$ :

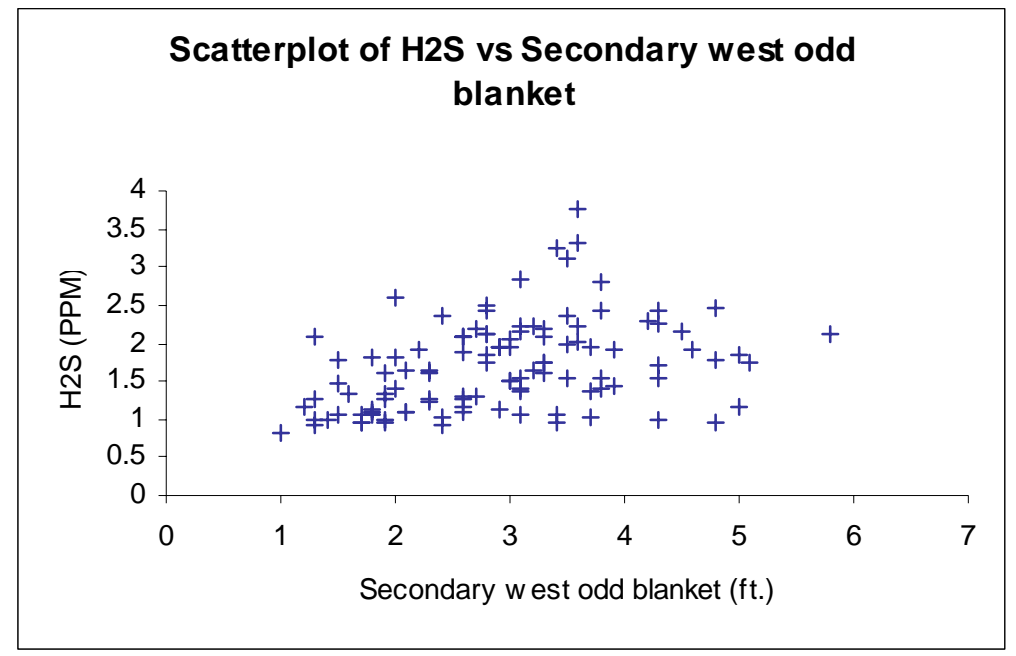

Appendix A-1: Scatterplot total reduced sulfur VS Secondary west odd blanket

\begin{tabular}{|ll|}
\hline & Secondary west odd blanket \\
Mean & 2.927 \\
Variance & 1.036 \\
Std. Dev. & 1.018 \\
Skewness & 0.3307 \\
Kurtosis & 2.6814 \\
Median & 2.900 \\
Mean Abs. Dev. & 0.820 \\
Minimum & 1.000 \\
Maximum & 5.800 \\
Range & 4.800 \\
Count & 108 \\
Sum & 316.100 \\
$\mathbf{1 . 0 0 \%}$ & 1.200 \\
$\mathbf{2 . 5 0 \%}$ & 1.300 \\
$\mathbf{5 . 0 0 \%}$ & 1.300 \\
$\mathbf{1 0 . 0 0 \%}$ & 1.600 \\
$\mathbf{2 0 . 0 0 \%}$ & 1.900 \\
$\mathbf{8 0 . 0 0 \%}$ & 3.700 \\
$\mathbf{9 0 . 0 0 \%}$ & 4.300 \\
$\mathbf{9 5 . 0 0 \%}$ & 4.800 \\
$\mathbf{9 7 . 5 0 \%}$ & 5.000 \\
$\mathbf{9 9 . 0 0 \%}$ & 5.100 \\
\hline
\end{tabular}


2. D secondary blanket $>3.8 \mathrm{ft}$ :

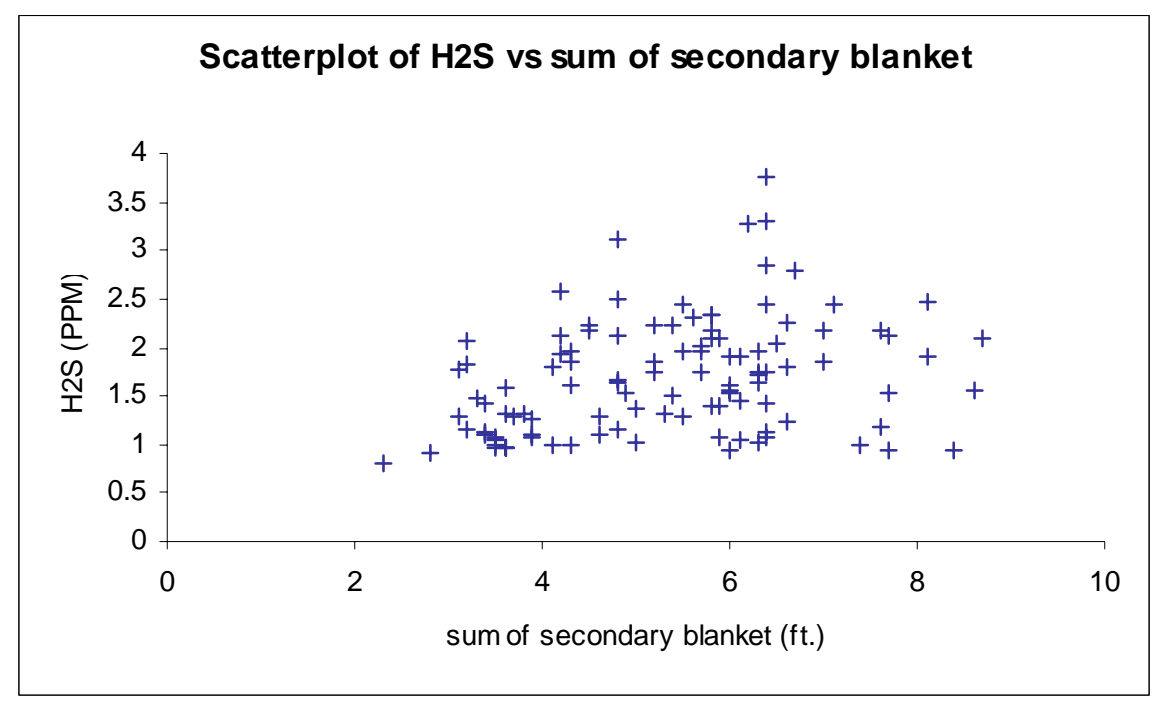

Appendix A-2: Scatter plot total reduced sulfur VS sum of secondary blanket

\begin{tabular}{|ll|}
\hline & sum of secondary blanket \\
Mean & 5.356 \\
Variance & 2.083 \\
Std. Dev. & 1.443 \\
Skewness & 0.1321 \\
Kurtosis & 2.3841 \\
Median & 5.500 \\
Mean Abs. Dev. & 1.203 \\
Minimum & 2.300 \\
Maximum & 8.700 \\
Range & 6.400 \\
Count & 108 \\
Sum & 578.400 \\
$\mathbf{1 . 0 0 \%}$ & 2.800 \\
$\mathbf{2 . 5 0 \%}$ & 3.100 \\
$\mathbf{5 . 0 0 \%}$ & 3.200 \\
$\mathbf{1 0 . 0 0 \%}$ & 3.400 \\
$\mathbf{2 0 . 0 0 \%}$ & 3.900 \\
$\mathbf{8 0 . 0 0 \%}$ & 6.400 \\
$\mathbf{9 0 . 0 0 \%}$ & 7.400 \\
$\mathbf{9 5 . 0 0 \%}$ & 7.700 \\
$\mathbf{9 7 . 5 0 \%}$ & 8.400 \\
$\mathbf{9 9 . 0 0 \%}$ & 8.600 \\
\hline
\end{tabular}


3. D polymer at dewatering process $>2760 \mathrm{lbs} / \mathrm{D}$ :

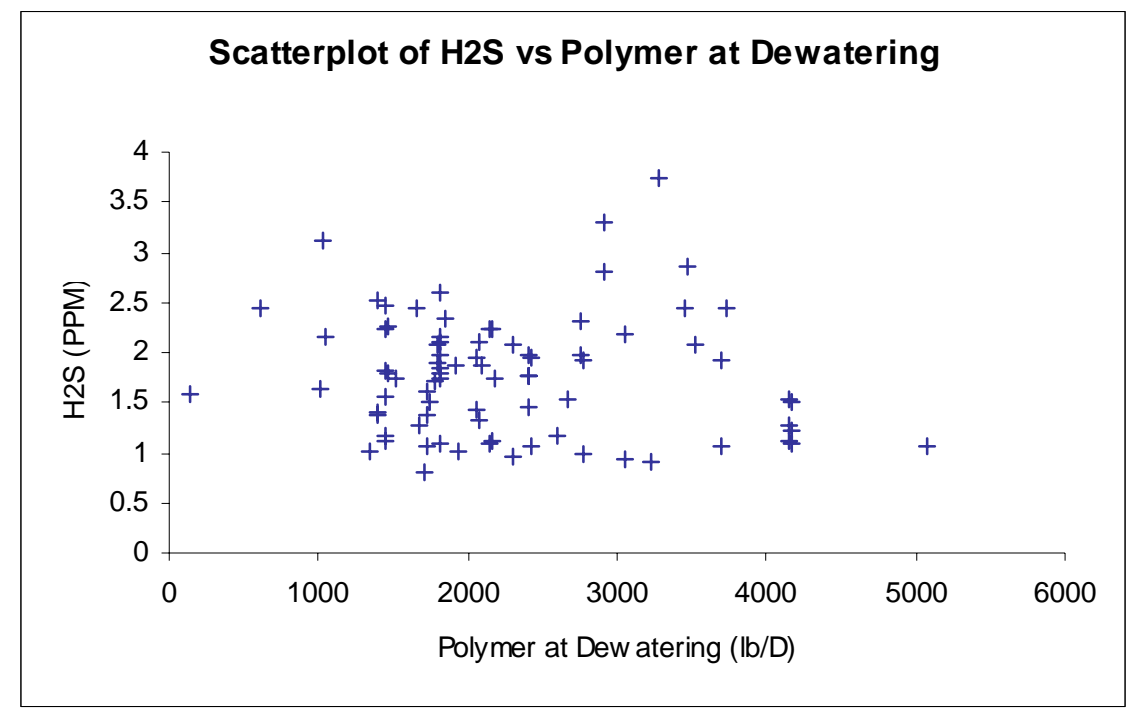

Appendix A-3: Scatter plot of total reduced sulfur VS polymer at dewatering process

\begin{tabular}{|ll|}
\hline & Polymer at Dewatering \\
Mean & 2276.24 \\
Variance & 881229.09 \\
Std. Dev. & 938.74 \\
Skewness & 0.7552 \\
Kurtosis & 3.3489 \\
Median & 2061.00 \\
Mean Abs. Dev. & 739.36 \\
Minimum & 145.00 \\
Maximum & 5076.92 \\
Range & 4931.92 \\
Count & 82 \\
Sum & 186651.67 \\
$\mathbf{1 . 0 0 \%}$ & 145.00 \\
$\mathbf{2 . 5 0} \%$ & 1019.00 \\
$\mathbf{5 . 0 0 \%}$ & 1049.00 \\
$\mathbf{7 0 . 0 0 \%}$ & 2592.00 \\
$\mathbf{7 5 . 0 0 \%}$ & 2769.23 \\
$\mathbf{8 5 . 0 0 \%}$ & 3450.00 \\
$\mathbf{9 0 . 0 0 \%}$ & 3700.10 \\
$\mathbf{9 5 . 0 0 \%}$ & 4153.84 \\
$\mathbf{9 7 . 5 0 \%}$ & 4162.61 \\
$\mathbf{9 9 . 0 0 \%}$ & 5076.92 \\
\hline
\end{tabular}




\section{Appendix B}

The followings are the models used to compare with the best model in February to August period:

Model 1. (Best)

\begin{tabular}{|c|c|c|c|c|c|c|}
\hline Summary & $\begin{array}{c}\text { Multiple } \\
\text { R } \\
0.4834\end{array}$ & $\begin{array}{c}\text { R-Square } \\
0.2337\end{array}$ & $\begin{array}{c}\text { Adjusted } \\
\text { R-Square } \\
0.2038\end{array}$ & $\begin{array}{c}\begin{array}{c}\text { StErr of } \\
\text { Estimate }\end{array} \\
0.530157096\end{array}$ & & \\
\hline $\begin{array}{l}\text { ANOVA Table } \\
\text { Explained } \\
\text { Unexplained }\end{array}$ & $\begin{array}{l}\text { Degrees of } \\
\text { Freedom } \\
3 \\
77\end{array}$ & $\begin{array}{c}\text { Sum of } \\
\text { Squares } \\
6.599526249 \\
21.64212404\end{array}$ & $\begin{array}{c}\text { Mean of } \\
\text { Squares } \\
2.199842083 \\
0.281066546\end{array}$ & $\begin{array}{l}\text { F-Ratio } \\
7.8268\end{array}$ & $\begin{array}{l}\text { p-Value } \\
0.0001\end{array}$ & \\
\hline $\begin{array}{l}\text { Regression Table } \\
\text { Constant } \\
\text { D secondary west odd blanket }>1.8 \mathrm{ft} \\
\text { D polymer at dewatering }>2760 \\
\text { Secondary west odd blanket }\end{array}$ & $\begin{array}{c}\text { Coefficient } \\
0.851639371 \\
0.409425821 \\
0.182400111 \\
0.170364219 \\
\end{array}$ & $\begin{array}{c}\text { Standard } \\
\text { Error }\end{array}$ & $\begin{array}{l}\text { t-Value } \\
4.2511 \\
1.9869 \\
1.3340 \\
2.3516 \\
\end{array}$ & $\begin{array}{c}\text { p-Value } \\
<0.0001 \\
0.0505 \\
0.1861 \\
0.0213 \\
\end{array}$ & $\begin{array}{c}\begin{array}{c}\text { Confider } \\
\text { Lower }\end{array} \\
0.452724254 \\
-0.00089722 \\
-0.08986412 \\
0.026106576\end{array}$ & $\begin{array}{c}\text { nterval 95\% } \\
\text { Upper } \\
1.250554488 \\
0.819748866 \\
0.454664339 \\
0.314621861\end{array}$ \\
\hline
\end{tabular}


Model 2.

\begin{tabular}{|l|c|c|c|c|c|c|}
\hline Summary & $\begin{array}{c}\text { Multiple } \\
\mathbf{R} \\
0.4175\end{array}$ & $\begin{array}{c}\text { R-Square } \\
0.1743\end{array}$ & $\begin{array}{c}\text { Adjusted } \\
\text { R-Square } \\
0.1449\end{array}$ & $\begin{array}{c}\text { StErr of } \\
\text { Estimate } \\
0.5797016\end{array}$ & & \\
\hline ANOVA Table & $\begin{array}{c}\text { Degrees of } \\
\text { Freedom }\end{array}$ & $\begin{array}{c}\text { Sum of } \\
\text { Squares }\end{array}$ & $\begin{array}{c}\text { Mean of } \\
\text { Squares }\end{array}$ & F-Ratio & p-Value & \\
$\begin{array}{l}\text { Explained } \\
\text { Unexplained }\end{array}$ & 3 & 5.960817919 & 1.98693931 & 5.9126 & 0.0010 & \\
\hline & 84 & 28.2285307 & 0.33605394 & & & \\
Regression Table & Coefficient & Standard & Error & t-Value & p-Value & \multicolumn{2}{|c|}{ Confidence Interval 95\% } \\
Constant & 1.200090081 & 0.333526047 & 3.5982 & 0.0005 & 0.536836961 & 1.863343202 \\
WPL & $-1.62509 \mathrm{E}-05$ & $1.63096 \mathrm{E}-05$ & -0.9964 & 0.3219 & $-4.86844 \mathrm{E}-05$ & $1.61826 \mathrm{E}-05$ \\
sum of secondary blanket & -0.021601524 & 0.070005023 & -0.3086 & 0.7584 & -0.160814189 & 0.117611141 \\
Secondary west odd blanket & 0.271733929 & 0.104323351 & 2.6047 & 0.0109 & 0.064275505 & 0.479192353 \\
\hline
\end{tabular}


Model 3.

\begin{tabular}{|c|c|c|c|c|c|c|}
\hline Summary & $\begin{array}{c}\text { Multiple } \\
\quad \mathbf{R} \\
0.6517\end{array}$ & $\begin{array}{c}\text { R-Square } \\
0.4248\end{array}$ & $\begin{array}{c}\text { Adjusted } \\
\text { R-Square } \\
0.2679\end{array}$ & $\begin{array}{c}\text { StErr of } \\
\text { Estimate } \\
0.55424814\end{array}$ & & \\
\hline $\begin{array}{l}\text { ANOVA Table } \\
\text { Explained } \\
\text { Unexplained }\end{array}$ & $\begin{array}{c}\text { Degrees of } \\
\text { Freedom } \\
9 \\
33\end{array}$ & $\begin{array}{c}\begin{array}{c}\text { Sum of } \\
\text { Squares }\end{array} \\
7.485557467 \\
10.13730286\end{array}$ & $\begin{array}{c}\text { Mean of } \\
\text { Squares } \\
0.831728607 \\
0.307190996\end{array}$ & $\begin{array}{l}\text { F-Ratio } \\
2.7075\end{array}$ & $\begin{array}{l}\text { p-Value } \\
0.0176\end{array}$ & \\
\hline & Coefficient & Standard & $t$-Value & $p$-Value & \multicolumn{2}{|c|}{ Confidence Interval 95\% } \\
\hline Regression Table & & Error & & & Lower & Upper \\
\hline Constant & 1.585531202 & 0.672784531 & 2.3567 & 0.0245 & 0.216740783 & 2.954321622 \\
\hline WPL & $-1.59826 \mathrm{E}-05$ & 3.89952E-05 & -0.4099 & 0.6846 & $-9.53188 E-05$ & 6.33537E-05 \\
\hline sum of secondary blanket & -0.28729951 & 0.137474406 & -2.0898 & 0.0444 & -0.566993292 & -0.007605727 \\
\hline D sum of secondary blanket (>3.8ft) & 0.35600799 & 0.62580827 & 0.5689 & 0.5733 & -0.917208509 & 1.629224489 \\
\hline D secondary west odd blanket $>1.8 \mathrm{ft}$ & -0.137027553 & 0.642588744 & -0.2132 & 0.8324 & -1.444384182 & 1.170329076 \\
\hline Sum of secondary blanket *Sum of RAS & $-1.55998 E-06$ & 6.19682E-06 & -0.2517 & 0.8028 & $-1.41675 E-05$ & 1.10475E-05 \\
\hline Sum of TPS\&TWAS * Polymer at dewatering & $-1.99354 \mathrm{E}-11$ & $2.28554 \mathrm{E}-11$ & -0.8722 & 0.3894 & $-6.6435 \mathrm{E}-11$ & $2.65642 \mathrm{E}-11$ \\
\hline Sum of secondary blanket * Polymer at DAF & 3.85405E-05 & 2.881E-05 & 1.3378 & 0.1901 & $-2.00738 \mathrm{E}-05$ & 9.71549E-05 \\
\hline D polymer at dewatering $>\mathbf{2 7 6 0}$ & 0.802775408 & 0.283499437 & 2.8317 & 0.0078 & 0.225991467 & 1.379559349 \\
\hline Secondary west odd blanket & 0.462409101 & 0.153466404 & 3.0131 & 0.0049 & 0.150179354 & 0.774638847 \\
\hline
\end{tabular}


Model 4

\begin{tabular}{|c|c|c|c|c|c|c|}
\hline Summary & $\begin{array}{c}\text { Multiple } \\
\text { R } \\
0.5142\end{array}$ & $\begin{array}{c}\text { R-Square } \\
0.2644\end{array}$ & $\begin{array}{c}\text { Adjusted } \\
\text { R-Square } \\
0.1418\end{array}$ & $\begin{array}{c}\text { StErr of } \\
\text { Estimate } \\
0.600088665\end{array}$ & & \\
\hline $\begin{array}{l}\text { ANOVA Table } \\
\text { Explained } \\
\text { Unexplained }\end{array}$ & $\begin{array}{c}\text { Degrees of } \\
\text { Freedom } \\
6 \\
36\end{array}$ & $\begin{array}{c}\text { Sum of } \\
\text { Squares } \\
4.659029716 \\
12.96383061\end{array}$ & $\begin{array}{c}\text { Mean of } \\
\text { Squares } \\
0.776504953 \\
0.360106406\end{array}$ & $\begin{array}{l}\text { F-Ratio } \\
2.1563\end{array}$ & $\begin{array}{l}\text { p-Value } \\
0.0705\end{array}$ & \\
\hline & Coefficient & Standard & t-Value & p-Value & \multicolumn{2}{|c|}{ Confidence Interval 95\% } \\
\hline Regression Table & & Error & & & Lower & Upper \\
\hline Constant & 0.988612049 & 0.675240974 & 1.4641 & 0.1518 & -0.380840119 & 2.358064217 \\
\hline WPL & 2.56999E-05 & 3.75512E-05 & 0.6844 & 0.4981 & $-5.04575 E-05$ & 0.000101857 \\
\hline sum of secondary blanket & -0.329503606 & 0.144889726 & -2.2742 & 0.0290 & -0.623353591 & -0.035653621 \\
\hline Sum of secondary blanket *Sum of RAS & 8.70364E-06 & 5.59891E-06 & 1.5545 & 0.1288 & $-2.65149 E-06$ & 2.00588E-05 \\
\hline Sum of TPS\&TWAS * Polymer at dewatering & $1.54814 \mathrm{E}-11$ & 2.07473E-11 & 0.7462 & 0.4604 & $-2.6596 E-11$ & 5.75588E-11 \\
\hline Sum of secondary blanket * Polymer at DAF & 7.29913E-05 & 2.81174E-05 & 2.5959 & 0.0136 & 1.59666E-05 & 0.000130016 \\
\hline Secondary west odd blanket & 0.315565757 & 0.136533263 & 2.3113 & 0.0267 & 0.038663465 & 0.592468049 \\
\hline
\end{tabular}


Model 5

\begin{tabular}{|c|c|c|c|c|c|c|}
\hline Summary & $\begin{array}{c}\text { Multiple } \\
\text { R } \\
0.4865\end{array}$ & $\begin{array}{c}\text { R-Square } \\
0.2367\end{array}$ & $\begin{array}{c}\text { Adjusted } \\
\text { R-Square } \\
0.1965\end{array}$ & $\begin{array}{c}\text { StErr of } \\
\text { Estimate } \\
0.532590902\end{array}$ & & \\
\hline $\begin{array}{l}\text { ANOVA Table } \\
\text { Explained } \\
\text { Unexplained }\end{array}$ & $\begin{array}{c}\text { Degrees of } \\
\text { Freedom } \\
4 \\
76\end{array}$ & $\begin{array}{c}\text { Sum of } \\
\text { Squares } \\
6.684017016 \\
21.55763328\end{array}$ & $\begin{array}{c}\text { Mean of } \\
\text { Squares } \\
1.671004254 \\
0.283653069\end{array}$ & $\begin{array}{l}\text { F-Ratio } \\
5.8910\end{array}$ & $\begin{array}{l}\text { p-Value } \\
0.0003\end{array}$ & \\
\hline $\begin{array}{l}\text { Regression Table } \\
\text { Constant } \\
\text { D sum of secondary blanket }(>3.8 \mathrm{ft}) \\
\text { D secondary west odd blanket }>1.8 \mathrm{ft} \\
\text { D polymer at dewatering }>2700 \\
\text { Secondary west odd blanket }\end{array}$ & $\begin{array}{c}\text { Coefficient } \\
0.855217441 \\
0.01495452 \\
0.401523714 \\
0.188511129 \\
0.165189222\end{array}$ & $\begin{array}{c}\begin{array}{c}\text { Standard } \\
\text { Error }\end{array} \\
0.198990817 \\
0.262810074 \\
0.269724533 \\
0.134332173 \\
0.075240439 \\
\end{array}$ & $\begin{array}{l}\text { t-Value } \\
4.2978 \\
0.0569 \\
1.4886 \\
1.4033 \\
2.1955\end{array}$ & $\begin{array}{c}\text { p-Value } \\
<0.0001 \\
0.9548 \\
0.1407 \\
0.1646 \\
0.0312\end{array}$ & $\begin{array}{c}\text { Confidence } \\
\text { Lower } \\
0.458892881 \\
-0.508477106 \\
-0.13567925 \\
-0.07903458 \\
0.015334899\end{array}$ & $\begin{array}{c}\text { erval 95\% } \\
\text { Upper } \\
1.251542 \\
0.538386146 \\
0.938726678 \\
0.456056837 \\
0.315043544\end{array}$ \\
\hline
\end{tabular}


Model 6.

\begin{tabular}{|c|c|c|c|c|c|c|}
\hline Summary & $\begin{array}{l}\text { Multiple } \\
\quad \mathbf{R} \\
0.4528\end{array}$ & $\begin{array}{l}\text { R-Square } \\
0.2050\end{array}$ & $\begin{array}{c}\text { Adjusted } \\
\text { R-Square } \\
0.1019\end{array}$ & $\begin{array}{c}\text { StErr of } \\
\text { Estimate } \\
0.549837962\end{array}$ & & \\
\hline $\begin{array}{l}\text { ANOVA Table } \\
\text { Explained } \\
\text { Unexplained }\end{array}$ & $\begin{array}{c}\text { Degrees of } \\
\text { Freedom } \\
7 \\
54\end{array}$ & $\begin{array}{c}\text { Sum of } \\
\text { Squares } \\
4.209293046 \\
16.32537639\end{array}$ & $\begin{array}{c}\text { Mean of } \\
\text { Squares } \\
0.601327578 \\
0.302321785\end{array}$ & $\begin{array}{l}\text { F-Ratio } \\
1.9890\end{array}$ & $\begin{array}{l}p \text {-Value } \\
0.0735\end{array}$ & \\
\hline & Coefficient & Standard & t-Value & p-Value & \multicolumn{2}{|c|}{ Confidence Interval 95\% } \\
\hline Regression Table & & $\begin{array}{c}\text { Error } \\
0303336338\end{array}$ & & & $\begin{array}{c}\text { Lower } \\
\text { (1) }\end{array}$ & Upper \\
\hline Constant & 1.203061421 & 0.302336338 & 3.9792 & 0.0002 & 0.596913561 & 1.809209282 \\
\hline D sum of secondary blanket (>3.8ft) & 0.149000721 & 0.423119671 & 0.3521 & 0.7261 & -0.699303143 & 0.997304585 \\
\hline D secondary west odd blanket $>1.8 \mathrm{ft}$ & 0.015812672 & 0.463377923 & 0.0341 & 0.9729 & -0.913204129 & 0.944829473 \\
\hline Sum of secondary blanket *Sum of RAS & $-4.8412 \mathrm{E}-06$ & 3.32495E-06 & -1.4560 & 0.1512 & -1.15073E-05 & 1.82493E-06 \\
\hline Sum of TPS\&TWAS * Polymer at dewatering & $-7.97678 \mathrm{E}-12$ & 1.73114E-11 & -0.4608 & 0.6468 & $-4.26841 E-11$ & 2.67305E-11 \\
\hline Sum of secondary blanket * Polymer at DAF & 8.65487E-06 & 2.06959E-05 & 0.4182 & 0.6775 & $-3.2838 \mathrm{E}-05$ & 5.01477E-05 \\
\hline D polymer at dewatering $>2760$ & 0.520420916 & 0.226086194 & 2.3019 & 0.0252 & 0.067145388 & 0.973696445 \\
\hline Secondary west odd blanket & 0.221426462 & 0.11848694 & 1.8688 & 0.0671 & -0.016125549 & 0.458978473 \\
\hline
\end{tabular}


Model 7.

\begin{tabular}{|c|c|c|c|c|c|c|}
\hline Summary & $\begin{array}{c}\text { Multiple } \\
\text { R } \\
0.4218\end{array}$ & $\begin{array}{c}\text { R-Square } \\
0.1780\end{array}$ & $\begin{array}{c}\text { Adjusted } \\
\text { R-Square } \\
0.1542\end{array}$ & $\begin{array}{c}\text { StErr of } \\
\text { Estimate } \\
0.544786014\end{array}$ & & \\
\hline $\begin{array}{l}\text { ANOVA Table } \\
\text { Explained } \\
\text { Unexplained }\end{array}$ & $\begin{array}{l}\text { Degrees of } \\
\text { Freedom } \\
3 \\
104\end{array}$ & $\begin{array}{c}\text { Sum of } \\
\text { Squares } \\
6.681924301 \\
30.86634732\end{array}$ & $\begin{array}{c}\text { Mean of } \\
\text { Squares } \\
2.2273081 \\
0.296791801\end{array}$ & $\begin{array}{l}\text { F-Ratio } \\
7.5046\end{array}$ & $\begin{array}{l}\text { p-Value } \\
0.0001\end{array}$ & \\
\hline $\begin{array}{l}\text { Regression Table } \\
\text { Constant } \\
\text { D sum of secondary blanket }(>3.8 \mathrm{ft}) \\
\text { D secondary west odd blanket }>1.8 \mathrm{ft} \\
\text { Secondary west odd blanket }\end{array}$ & $\begin{array}{c}\text { Coefficient } \\
1.00081331 \\
0.178672964 \\
0.203117617 \\
0.132054954 \\
\end{array}$ & $\begin{array}{c}\text { Standard } \\
\text { Error } \\
0.16304465 \\
0.225237944 \\
0.23454697 \\
0.069843953\end{array}$ & $\begin{array}{l}\text { t-Value } \\
6.1383 \\
0.7933 \\
0.8660 \\
1.8907 \\
\end{array}$ & $\begin{array}{c}\text { p-Value } \\
<0.0001 \\
0.4294 \\
0.3885 \\
0.0614 \\
\end{array}$ & $\begin{array}{c}\begin{array}{c}\text { Confidence } \\
\text { Lower }\end{array} \\
0.67748965 \\
-0.267982333 \\
-0.261997825 \\
-0.006448226\end{array}$ & $\begin{array}{c}\text { erval 95\% } \\
\text { Upper } \\
1.32413697 \\
0.62532826 \\
0.66823306 \\
0.270558134\end{array}$ \\
\hline
\end{tabular}


Model 8.

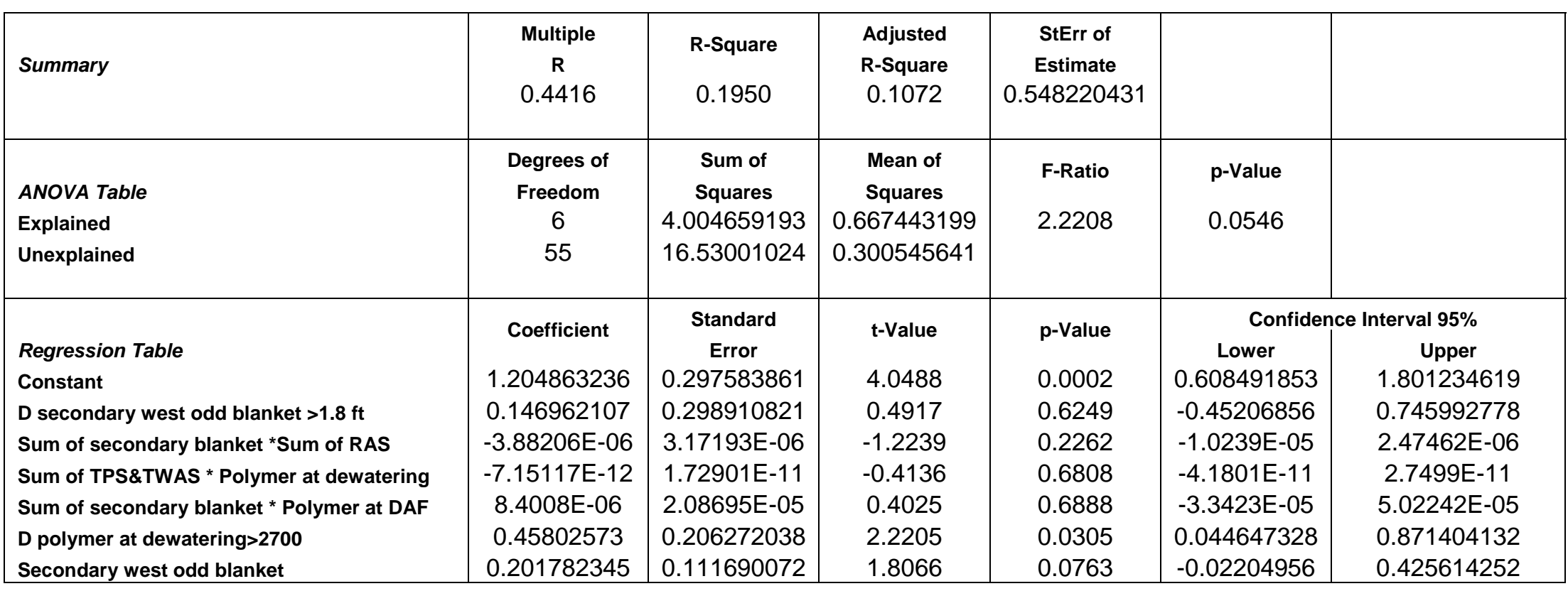


Model 9.

\begin{tabular}{|c|c|c|c|c|c|c|}
\hline Summary & $\begin{array}{l}\text { Multiple } \\
\quad \mathbf{R} \\
0.4602\end{array}$ & $\begin{array}{c}\text { R-Square } \\
0.2118\end{array}$ & $\begin{array}{c}\text { Adjusted } \\
\text { R-Square } \\
0.1811\end{array}$ & $\begin{array}{c}\text { StErr of } \\
\text { Estimate } \\
0.537666862\end{array}$ & & \\
\hline $\begin{array}{l}\text { ANOVA Table } \\
\text { Explained } \\
\text { Unexplained }\end{array}$ & $\begin{array}{c}\text { Degrees of } \\
\text { Freedom } \\
3 \\
77\end{array}$ & $\begin{array}{c}\begin{array}{c}\text { Sum of } \\
\text { Squares }\end{array} \\
5.982054864 \\
22.25959543\end{array}$ & $\begin{array}{c}\text { Mean of } \\
\text { Squares } \\
1.994018288 \\
0.289085655\end{array}$ & $\begin{array}{l}\text { F-Ratio } \\
6.8977\end{array}$ & $\begin{array}{l}p \text {-Value } \\
0.0004\end{array}$ & \\
\hline $\begin{array}{l}\text { Regression Table } \\
\text { Constant } \\
\text { D sum of secondary blanket (>3.8ft) } \\
\text { D polymer at dewatering }>2760 \\
\text { Secondary west odd blanket }\end{array}$ & $\begin{array}{c}\text { Coefficient } \\
0.901089415 \\
0.266121078 \\
0.163773961 \\
0.197079267 \\
\end{array}$ & \begin{tabular}{c|}
$\begin{array}{c}\text { Standard } \\
\text { Error }\end{array}$ \\
0.200334174 \\
0.203966597 \\
0.140502516 \\
0.07424874 \\
\end{tabular} & $\begin{array}{l}\text { t-Value } \\
4.4979 \\
1.3047 \\
1.1656 \\
2.6543 \\
\end{array}$ & $\begin{array}{c}p \text {-Value } \\
<0.0001 \\
0.1959 \\
0.2474 \\
0.0097\end{array}$ & $\begin{array}{c}\text { Confide } \\
\text { Lower } \\
0.50217311 \\
-0.140028305 \\
-0.116002291 \\
0.049231137 \\
\end{array}$ & $\begin{array}{c}\text { terval } 95 \% \\
\text { Upper } \\
1.30000572 \\
0.672270462 \\
0.443550214 \\
0.344927398 \\
\end{array}$ \\
\hline
\end{tabular}




\section{Appendix C}

The followings are the models used to compare with the best model in February to April period:

Model 1. (Best)

\begin{tabular}{|c|c|c|c|c|c|c|}
\hline Summary & $\begin{array}{l}\text { Multiple } \\
\quad \mathbf{R} \\
0.5434\end{array}$ & $\begin{array}{l}\text { R-Square } \\
0.2953\end{array}$ & $\begin{array}{c}\text { Adjusted } \\
\text { R-Square } \\
0.2582\end{array}$ & $\begin{array}{c}\text { StErr of } \\
\text { Estimate } \\
0.52542695\end{array}$ & & \\
\hline $\begin{array}{l}\text { ANOVA Table } \\
\text { Explained } \\
\text { Unexplained }\end{array}$ & $\begin{array}{c}\text { Degrees of } \\
\text { Freedom } \\
1 \\
19\end{array}$ & $\begin{array}{c}\text { Sum of } \\
\text { Squares } \\
2.198260417 \\
5.245396174\end{array}$ & $\begin{array}{c}\text { Mean of } \\
\text { Squares } \\
2.198260417 \\
0.276073483\end{array}$ & $\begin{array}{l}\text { F-Ratio } \\
7.9626\end{array}$ & $\begin{array}{l}\text { p-Value } \\
0.0109\end{array}$ & \\
\hline $\begin{array}{l}\text { Regression Table } \\
\text { Constant } \\
\text { Secondary west odd blanket dept }\end{array}$ & $\begin{array}{c}\text { Coefficient } \\
\\
0.289619753 \\
0.490648196 \\
\end{array}$ & $\begin{array}{c}\text { Standard } \\
\text { Error } \\
0.459174778 \\
0.173877339 \\
\end{array}$ & $\begin{array}{l}\text { t-Value } \\
0.6307 \\
2.8218\end{array}$ & $\begin{array}{l}\text { p-Value } \\
0.5357 \\
0.0109\end{array}$ & $\begin{array}{c}\text { Confidenc } \\
\text { Lower } \\
-0.671444102 \\
0.126718744\end{array}$ & $\begin{array}{c}\text { terval 95\% } \\
\text { Upper } \\
1.250683608 \\
0.854577648 \\
\end{array}$ \\
\hline
\end{tabular}


Model 2.

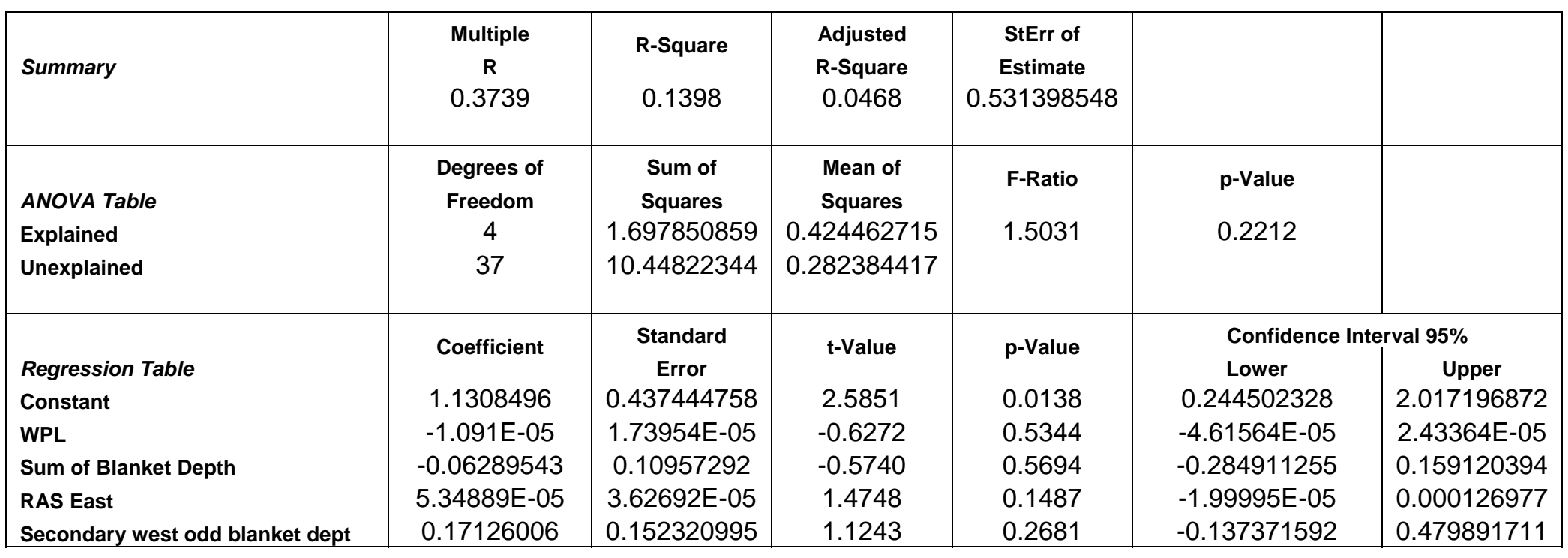


Model 3.

\begin{tabular}{|c|c|c|c|c|c|c|}
\hline Summary & $\begin{array}{l}\text { Multiple } \\
\quad \mathbf{R} \\
0.3635\end{array}$ & $\begin{array}{c}\text { R-Square } \\
0.1321\end{array}$ & $\begin{array}{c}\text { Adjusted } \\
\text { R-Square } \\
0.0636\end{array}$ & $\begin{array}{c}\text { StErr of } \\
\text { Estimate } \\
0.526689363\end{array}$ & & \\
\hline $\begin{array}{l}\text { ANOVA Table } \\
\text { Explained } \\
\text { Unexplained }\end{array}$ & $\begin{array}{c}\text { Degrees of } \\
\text { Freedom } \\
3 \\
38\end{array}$ & $\begin{array}{c}\text { Sum of } \\
\text { Squares } \\
1.604810272 \\
10.54126402\end{array}$ & $\begin{array}{c}\text { Mean of } \\
\text { Squares } \\
0.5349368 \\
0.2774017\end{array}$ & $\begin{array}{l}\text { F-Ratio } \\
1.9284\end{array}$ & $\begin{array}{l}p \text {-Value } \\
0.1414\end{array}$ & \\
\hline & Coefficient & Standard & t-Value & p-Value & \multicolumn{2}{|c|}{ Confidence Interval 95\% } \\
\hline Regression Table & & Error & & & Lower & Upper \\
\hline Constant & 0.99730465 & 0.367162517 & 2.7162 & 0.0099 & 0.254022994 & 1.740586307 \\
\hline WPL & -8.68637E-06 & 1.68083E-05 & -0.5168 & 0.6083 & $-4.2713 \mathrm{E}-05$ & $2.53402 \mathrm{E}-05$ \\
\hline RAS East & 4.37039E-05 & 3.17297E-05 & 1.3774 & 0.1765 & $-2.053 E-05$ & 0.000107937 \\
\hline Secondary west odd blanket dept & 0.109989769 & 0.107701179 & 1.0212 & 0.3136 & -0.10803987 & 0.328019407 \\
\hline
\end{tabular}


Model 4.

\begin{tabular}{|c|c|c|c|c|c|c|}
\hline Summary & $\begin{array}{c}\text { Multiple } \\
\quad \mathbf{R} \\
0.6341\end{array}$ & $\begin{array}{c}\text { R-Square } \\
0.4020\end{array}$ & $\begin{array}{c}\text { Adjusted } \\
\text { R-Square } \\
0.2027\end{array}$ & $\begin{array}{c}\text { StErr of } \\
\text { Estimate } \\
0.505194747\end{array}$ & & \\
\hline $\begin{array}{l}\text { ANOVA Table } \\
\text { Explained } \\
\text { Unexplained }\end{array}$ & $\begin{array}{c}\text { Degrees of } \\
\text { Freedom } \\
5 \\
15\end{array}$ & $\begin{array}{c}\text { Sum of } \\
\text { Squares } \\
2.574057985 \\
3.828325986\end{array}$ & $\begin{array}{c}\text { Mean of } \\
\text { Squares } \\
0.514811597 \\
0.255221732\end{array}$ & $\begin{array}{l}\text { F-Ratio } \\
2.0171\end{array}$ & $\begin{array}{l}p \text {-Value } \\
0.1343\end{array}$ & \\
\hline & Coefficient & Standard & t-Value & p-Value & \multicolumn{2}{|c|}{ Confidence Interval 95\% } \\
\hline Regression Table & & & & & Lower & Upper \\
\hline Constant & 4.244125645 & 1.176279453 & 3.6081 & 0.0026 & 1.736945339 & 6.75130595 \\
\hline WPL & $-3.38125 E-05$ & 3.44933E-05 & -0.9803 & 0.3425 & -0.000107333 & 3.97083E-05 \\
\hline D sum of secondary blanket $>3.8$ & -1.694507562 & 0.813955628 & -2.0818 & 0.0549 & -3.429412916 & 0.040397792 \\
\hline Sum of secondary blanket * Polymer at DAF & $-5.25789 \mathrm{E}-05$ & 2.14408E-05 & -2.4523 & 0.0269 & $-9.82788 E-05$ & $-6.87907 E-06$ \\
\hline RAS East & 2.55571E-05 & $4.36252 \mathrm{E}-05$ & 0.5858 & 0.5667 & $-6.74278 \mathrm{E}-05$ & 0.000118542 \\
\hline Secondary west odd blanket dept & -0.10971923 & 0.177782129 & -0.6172 & 0.5464 & -0.488652869 & 0.269214409 \\
\hline
\end{tabular}


Model 5.

\begin{tabular}{|c|c|c|c|c|c|c|}
\hline Summary & $\begin{array}{c}\text { Multiple } \\
\text { R } \\
0.3967\end{array}$ & $\begin{array}{c}\text { R-Square } \\
0.1574\end{array}$ & $\begin{array}{c}\text { Adjusted } \\
\text { R-Square } \\
0.0403\end{array}$ & $\begin{array}{c}\text { StErr of } \\
\text { Estimate } \\
0.533195619\end{array}$ & & \\
\hline $\begin{array}{l}\text { ANOVA Table } \\
\text { Explained } \\
\text { Unexplained }\end{array}$ & $\begin{array}{c}\text { Degrees of } \\
\text { Freedom } \\
5 \\
36\end{array}$ & $\begin{array}{c}\text { Sum of } \\
\text { Squares } \\
1.911361831 \\
10.23471247\end{array}$ & $\begin{array}{c}\text { Mean of } \\
\text { Squares } \\
0.382272366 \\
0.284297568\end{array}$ & $\begin{array}{l}\text { F-Ratio } \\
1.3446\end{array}$ & $\begin{array}{l}\text { p-Value } \\
0.2681\end{array}$ & \\
\hline $\begin{array}{l}\text { Regression Table } \\
\text { Constant } \\
\text { WPL } \\
\text { D secondary west odd blanket }>1.8 \\
\text { D sum of secondary blanket }>3.8 \\
\text { RAS East } \\
\text { Secondary west odd blanket dept }\end{array}$ & $\begin{array}{c}\text { Coefficient } \\
1.061883568 \\
-8.68893 \mathrm{E}-06 \\
0.177426098 \\
0.157062825 \\
3.80231 \mathrm{E}-05 \\
0.002167611 \\
\end{array}$ & $\begin{array}{c}\begin{array}{c}\text { Standard } \\
\text { Error }\end{array} \\
0.377272377 \\
1.70286 \mathrm{E}-05 \\
0.42172285 \\
0.403982787 \\
3.26929 \mathrm{E}-05 \\
0.151250904 \\
\end{array}$ & $\begin{array}{c}\text { t-Value } \\
\\
2.8146 \\
-0.5103 \\
0.4207 \\
0.3888 \\
1.1630 \\
0.0143 \\
\end{array}$ & $\begin{array}{l}\text { p-Value } \\
0.0079 \\
0.6130 \\
0.6765 \\
0.6997 \\
0.2525 \\
0.9886 \\
\end{array}$ & $\begin{array}{c}\text { Confide } \\
\text { Lower } \\
0.296739723 \\
-4.32245 E-05 \\
-0.677867485 \\
-0.662252242 \\
-2.82812 E-05 \\
-0.304583439 \\
\end{array}$ & $\begin{array}{c}\text { terval } 95 \% \\
\text { Upper } \\
1.827027412 \\
2.58466 \mathrm{E}-05 \\
1.03271968 \\
0.976377893 \\
0.000104327 \\
0.308918661 \\
\end{array}$ \\
\hline
\end{tabular}


Model 6.

\begin{tabular}{|c|c|c|c|c|c|c|}
\hline Summary & $\begin{array}{c}\text { Multiple } \\
\mathbf{R} \\
0.5573\end{array}$ & $\begin{array}{c}\text { R-Square } \\
0.3105\end{array}$ & $\begin{array}{c}\text { Adjusted } \\
\text { R-Square } \\
0.2017\end{array}$ & $\begin{array}{c}\text { StErr of } \\
\text { Estimate } \\
0.532999213\end{array}$ & & \\
\hline $\begin{array}{l}\text { ANOVA Table } \\
\text { Explained } \\
\text { Unexplained }\end{array}$ & $\begin{array}{c}\text { Degrees of } \\
\text { Freedom } \\
3 \\
19\end{array}$ & $\begin{array}{c}\text { Sum of } \\
\text { Squares } \\
2.431067035 \\
5.397675066\end{array}$ & $\begin{array}{c}\text { Mean of } \\
\text { Squares } \\
0.810355678 \\
0.284088161\end{array}$ & $\begin{array}{l}\text { F-Ratio } \\
2.8525\end{array}$ & $\begin{array}{l}p \text {-Value } \\
0.0646\end{array}$ & \\
\hline $\begin{array}{l}\text { Regression Table } \\
\text { Constant } \\
\text { D secondary west odd blanket }>1.8 \\
\text { D polymer at dewatering }>2760 \\
\text { Secondary west odd blanket dept }\end{array}$ & \begin{tabular}{c|} 
Coefficient \\
0.373490258 \\
0.152316998 \\
0.037967768 \\
0.391969481 \\
\end{tabular} & $\begin{array}{c}\text { Standard } \\
\text { Error } \\
0.522084167 \\
0.416348219 \\
0.249949414 \\
0.247282049 \\
\end{array}$ & $\begin{array}{l}\mathrm{t} \text {-Value } \\
0.7154 \\
0.3658 \\
0.1519 \\
1.5851 \\
\end{array}$ & $\begin{array}{l}\text { p-Value } \\
0.4831 \\
0.7185 \\
0.8809 \\
0.1294 \\
\end{array}$ & $\begin{array}{c}\text { Confider } \\
\text { Lower } \\
-0.719244461 \\
-0.71910984 \\
-0.485182368 \\
-0.125597796 \\
\end{array}$ & $\begin{array}{c}\text { val 95\% } \\
\text { Upper } \\
1.466224978 \\
1.023743835 \\
0.561117904 \\
0.909536759 \\
\end{array}$ \\
\hline
\end{tabular}


Model 7.

\begin{tabular}{|c|c|c|c|c|c|c|}
\hline Summary & $\begin{array}{l}\text { Multiple } \\
\quad \mathbf{R} \\
0.5564\end{array}$ & $\begin{array}{c}\text { R-Square } \\
0.3096\end{array}$ & $\begin{array}{c}\text { Adjusted } \\
\text { R-Square } \\
0.2006\end{array}$ & $\begin{array}{c}\text { StErr of } \\
\text { Estimate } \\
0.533371461\end{array}$ & & \\
\hline $\begin{array}{l}\text { ANOVA Table } \\
\text { Explained } \\
\text { Unexplained }\end{array}$ & $\begin{array}{c}\text { Degrees of } \\
\text { Freedom } \\
3 \\
19\end{array}$ & $\begin{array}{c}\text { Sum of } \\
\text { Squares } \\
2.423524904 \\
5.405217197\end{array}$ & $\begin{array}{c}\text { Mean of } \\
\text { Squares } \\
0.807841635 \\
0.284485116\end{array}$ & $\begin{array}{l}\text { F-Ratio } \\
2.8397\end{array}$ & $\begin{array}{l}p \text {-Value } \\
0.0654\end{array}$ & \\
\hline $\begin{array}{l}\text { Regression Table } \\
\text { Constant } \\
\text { D sum of secondary blanket }>3.8 \\
\text { D polymer at dewatering }>2760 \\
\text { Secondary west odd blanket dept }\end{array}$ & $\begin{array}{c}\text { Coefficient } \\
0.329638697 \\
0.12638925 \\
0.035992354 \\
0.415567819\end{array}$ & $\begin{array}{c}\text { Standard } \\
\text { Error } \\
0.497531703 \\
0.386129009 \\
0.251154877 \\
0.211953025\end{array}$ & $\begin{array}{l}\text { t-Value } \\
0.6625 \\
0.3273 \\
0.1433 \\
1.9607\end{array}$ & $\begin{array}{l}p \text {-Value } \\
0.5156 \\
0.7470 \\
0.8876 \\
0.0647\end{array}$ & $\begin{array}{c}\text { Confide } \\
\text { Lower } \\
-0.711707124 \\
-0.681788053 \\
-0.489680844 \\
-0.028054962\end{array}$ & $\begin{array}{c}\text { terval 95\% } \\
\text { Upper } \\
1.370984518 \\
0.934566553 \\
0.561665552 \\
0.859190599\end{array}$ \\
\hline
\end{tabular}


Model 8.

\begin{tabular}{|c|c|c|c|c|c|c|}
\hline Summary & $\begin{array}{c}\text { Multiple } \\
\quad \mathbf{R} \\
0.3366\end{array}$ & $\begin{array}{c}\text { R-Square } \\
0.1133\end{array}$ & $\begin{array}{c}\text { Adjusted } \\
\text { R-Square } \\
0.0690\end{array}$ & $\begin{array}{c}\text { StErr of } \\
\text { Estimate } \\
0.519241195\end{array}$ & & \\
\hline $\begin{array}{l}\text { ANOVA Table } \\
\text { Explained } \\
\text { Unexplained }\end{array}$ & $\begin{array}{c}\text { Degrees of } \\
\text { Freedom } \\
2 \\
40\end{array}$ & $\begin{array}{c}\text { Sum of } \\
\text { Squares } \\
1.378224701 \\
10.78445676\end{array}$ & $\begin{array}{c}\text { Mean of } \\
\text { Squares } \\
0.689112351 \\
0.269611419\end{array}$ & $\begin{array}{l}\text { F-Ratio } \\
2.5559\end{array}$ & $\begin{array}{l}p \text {-Value } \\
0.0902\end{array}$ & \\
\hline $\begin{array}{l}\text { Regression Table } \\
\text { Constant } \\
\text { D secondary west odd blanket }>1.8 \\
\text { Secondary west odd blanket dept }\end{array}$ & $\begin{array}{c}\text { Coefficient } \\
1.088395549 \\
0.346520653 \\
0.056423138\end{array}$ & $\begin{array}{c}\begin{array}{c}\text { Standard } \\
\text { Error }\end{array} \\
0.259158903 \\
0.285416117 \\
0.136693628\end{array}$ & $\begin{array}{l}\mathrm{t} \text {-Value } \\
4.1997 \\
1.2141 \\
0.4128\end{array}$ & $\begin{array}{l}p \text {-Value } \\
0.0001 \\
0.2318 \\
0.6820\end{array}$ & $\begin{array}{c}\text { Confiden } \\
\text { Lower } \\
0.564615871 \\
-0.230326835 \\
-0.219844988\end{array}$ & $\begin{array}{c}\text { erval 95\% } \\
\text { Upper } \\
1.612175227 \\
0.923368141 \\
0.332691265\end{array}$ \\
\hline
\end{tabular}


Model 9.

\begin{tabular}{|c|c|c|c|c|c|c|}
\hline Summary & $\begin{array}{c}\text { Multiple } \\
\quad \mathbf{R} \\
0.3424\end{array}$ & $\begin{array}{c}\text { R-Square } \\
0.1172\end{array}$ & $\begin{array}{c}\text { Adjusted } \\
\text { R-Square } \\
0.0731\end{array}$ & $\begin{array}{c}\text { StErr of } \\
\text { Estimate } \\
0.518094908\end{array}$ & & \\
\hline $\begin{array}{l}\text { ANOVA Table } \\
\text { Explained } \\
\text { Unexplained }\end{array}$ & $\begin{array}{c}\text { Degrees of } \\
\text { Freedom } \\
2 \\
40\end{array}$ & $\begin{array}{c}\text { Sum of } \\
\text { Squares } \\
1.425788116 \\
10.73689334\end{array}$ & $\begin{array}{c}\text { Mean of } \\
\text { Squares } \\
0.712894058 \\
0.268422334\end{array}$ & $\begin{array}{l}\text { F-Ratio } \\
2.6559\end{array}$ & $\begin{array}{l}p \text {-Value } \\
0.0826\end{array}$ & \\
\hline $\begin{array}{l}\text { Regression Table } \\
\text { Constant } \\
\text { D sum of secondary blanket }>3.8 \\
\text { Secondary west odd blanket dept }\end{array}$ & $\begin{array}{c}\text { Coefficient } \\
1.073986752 \\
0.349067981 \\
0.061156434\end{array}$ & $\begin{array}{c}\begin{array}{c}\text { Standard } \\
\text { Error }\end{array} \\
0.257082207 \\
0.271114015 \\
0.129843958\end{array}$ & $\begin{array}{l}\text { t-Value } \\
4.1776 \\
1.2875 \\
0.4710\end{array}$ & $\begin{array}{l}\text { p-Value } \\
0.0002 \\
0.2053 \\
0.6402\end{array}$ & $\begin{array}{c}\text { Confidenc } \\
\text { Lower } \\
0.554404231 \\
-0.198873882 \\
-0.201267993\end{array}$ & $\begin{array}{c}\text { terval 95\% } \\
\text { Upper } \\
1.593569273 \\
0.897009843 \\
0.323580861\end{array}$ \\
\hline
\end{tabular}




\section{Appendix D}

The followings are the models used to compare with the best model in May to August period:

Model 1 (Best).

\begin{tabular}{|c|c|c|c|c|c|c|}
\hline Summary & $\begin{array}{c}\text { Multiple } \\
\quad \mathbf{R} \\
0.6464\end{array}$ & $\begin{array}{c}\text { R-Square } \\
0.4179\end{array}$ & $\begin{array}{c}\text { Adjusted } \\
\text { R-Square } \\
0.3892\end{array}$ & $\begin{array}{c}\text { StErr of } \\
\text { Estimate } \\
0.46641899\end{array}$ & & \\
\hline $\begin{array}{l}\text { ANOVA Table } \\
\text { Explained } \\
\text { Unexplained }\end{array}$ & $\begin{array}{c}\text { Degrees of } \\
\text { Freedom } \\
3 \\
61\end{array}$ & $\begin{array}{c}\text { Sum of } \\
\text { Squares } \\
9.525825092 \\
13.27034711\end{array}$ & $\begin{array}{c}\text { Mean of } \\
\text { Squares } \\
3.175275031 \\
0.217546674\end{array}$ & $\begin{array}{c}\text { F-Ratio } \\
14.5958\end{array}$ & $\begin{array}{c}\text { p-Value } \\
<0.0001\end{array}$ & \\
\hline $\begin{array}{l}\text { Regression Table } \\
\text { Constant } \\
\text { D secondary west odd blanket }>1.8 \\
\text { D polymer at dewatering }>2760 \\
\text { Secondary west odd blanket }\end{array}$ & $\begin{array}{c}\text { Coefficient } \\
1.109769043 \\
0.36646254 \\
1.103733584 \\
0.100953453\end{array}$ & $\begin{array}{c}\begin{array}{c}\text { Standard } \\
\text { Error }\end{array} \\
0.189169221 \\
0.204892671 \\
0.219314268 \\
0.066888178\end{array}$ & $\begin{array}{l}\text { t-Value } \\
5.8665 \\
1.7886 \\
5.0327 \\
1.5093\end{array}$ & $\begin{array}{c}\text { p-Value } \\
<0.0001 \\
0.0787 \\
<0.0001 \\
0.1364\end{array}$ & $\begin{array}{c}\begin{array}{c}\text { Confider } \\
\text { Lower }\end{array} \\
0.731501808 \\
-0.043245677 \\
0.665187601 \\
-0.032797725 \\
\end{array}$ & $\begin{array}{c}\text { nterval } 95 \% \\
\text { Upper } \\
1.488036278 \\
0.776170758 \\
1.542279567 \\
0.234704631 \\
\end{array}$ \\
\hline
\end{tabular}


Model 2.

\begin{tabular}{|c|c|c|c|c|c|c|}
\hline Summary & $\begin{array}{l}\text { Multiple } \\
\quad \mathbf{R} \\
0.7020\end{array}$ & $\begin{array}{c}\text { R-Square } \\
0.4928\end{array}$ & $\begin{array}{c}\text { Adjusted } \\
\text { R-Square } \\
0.3711\end{array}$ & $\begin{array}{c}\text { StErr of } \\
\text { Estimate } \\
0.508486323\end{array}$ & & \\
\hline $\begin{array}{l}\text { ANOVA Table } \\
\text { Explained } \\
\text { Unexplained }\end{array}$ & $\begin{array}{c}\text { Degrees of } \\
\text { Freedom } \\
6 \\
25\end{array}$ & $\begin{array}{c}\text { Sum of } \\
\text { Squares } \\
6.281164878 \\
6.463958506\end{array}$ & $\begin{array}{c}\text { Mean of } \\
\text { Squares } \\
1.046860813 \\
0.25855834\end{array}$ & $\begin{array}{l}\text { F-Ratio } \\
4.0488\end{array}$ & $\begin{array}{l}p \text {-Value } \\
0.0057\end{array}$ & \\
\hline $\begin{array}{l}\text { Regression Table } \\
\text { Constant } \\
\text { Polymer at DAF } \\
\text { Polymer at Dewatering } \\
\text { WPL } \\
\text { Sum of Blanket Depth } \\
\% \text { of TWAS in Blend Tank } \\
\text { Secondary west odd blanket }\end{array}$ & $\begin{array}{c}\text { Coefficient } \\
-3.615319613 \\
0.000713448 \\
0.000246836 \\
0.000194831 \\
0.208185868 \\
-0.175409586 \\
0.079516286\end{array}$ & $\begin{array}{c}\begin{array}{c}\text { Standard } \\
\text { Error }\end{array} \\
1.252001286 \\
0.000249928 \\
0.000191041 \\
6.15522 \mathrm{E}-05 \\
0.123872468 \\
1.329562281 \\
0.177606724\end{array}$ & $\begin{array}{c}\text { t-Value } \\
\\
-2.8876 \\
2.8546 \\
1.2921 \\
3.1653 \\
1.6806 \\
-0.1319 \\
0.4477 \\
\end{array}$ & $\begin{array}{l}p \text {-Value } \\
\\
0.0079 \\
0.0085 \\
0.2082 \\
0.0040 \\
0.1053 \\
0.8961 \\
0.6582\end{array}$ & $\begin{array}{c}\begin{array}{c}\text { Confidence } \\
\text { Lower }\end{array} \\
-6.19386453 \\
0.000198712 \\
-0.00014662 \\
6.80616 \mathrm{E}-05 \\
-0.046934255 \\
-2.913694361 \\
-0.286271609\end{array}$ & $\begin{array}{c}\text { val } 95 \% \\
\text { Upper } \\
-1.036774696 \\
0.001228184 \\
0.000640292 \\
0.0003216 \\
0.463305991 \\
2.56287519 \\
0.445304182\end{array}$ \\
\hline
\end{tabular}


Model 3.

\begin{tabular}{|c|c|c|c|c|c|c|}
\hline Summary & $\begin{array}{l}\text { Multiple } \\
\quad \mathbf{R} \\
0.8076\end{array}$ & $\begin{array}{c}\text { R-Square } \\
0.6523\end{array}$ & $\begin{array}{c}\text { Adjusted } \\
\text { R-Square } \\
0.4327\end{array}$ & $\begin{array}{c}\text { StErr of } \\
\text { Estimate } \\
0.482954239\end{array}$ & & \\
\hline $\begin{array}{l}\text { ANOVA Table } \\
\text { Explained } \\
\text { Unexplained }\end{array}$ & $\begin{array}{c}\text { Degrees of } \\
\text { Freedom } \\
12 \\
19\end{array}$ & $\begin{array}{c}\text { Sum of } \\
\text { Squares } \\
8.313472246 \\
4.431651138\end{array}$ & $\begin{array}{c}\text { Mean of } \\
\text { Squares } \\
0.692789354 \\
0.233244797\end{array}$ & $\begin{array}{l}\text { F-Ratio } \\
2.9702\end{array}$ & $\begin{array}{l}\text { p-Value } \\
0.0167\end{array}$ & \\
\hline & Coefficient & Standard & t-Value & p-Value & \multicolumn{2}{|c|}{ Confidence Interval 95\% } \\
\hline Regression Table & & Error & Mainc & praice & Lower & Upper \\
\hline Constant & 1.962490971 & 3.004766946 & 0.6531 & 0.5215 & -4.326558525 & 8.251540468 \\
\hline Polymer at DAF & -0.000762426 & 0.001087949 & -0.7008 & 0.4919 & -0.003039528 & 0.001514677 \\
\hline Polymer at Dewatering & -0.000169795 & 0.000241429 & -0.7033 & 0.4904 & -0.000675112 & 0.000335523 \\
\hline WPL & 9.51313E-05 & 7.85496E-05 & 1.2111 & 0.2407 & $-6.92749 E-05$ & 0.000259537 \\
\hline Sum of Blanket Depth & -0.240613462 & 0.343734059 & -0.7000 & 0.4924 & -0.960057114 & 0.478830191 \\
\hline$\%$ of TWAS in Blend Tank & -0.733357563 & 1.360686114 & -0.5390 & 0.5962 & -3.58130633 & 2.114591204 \\
\hline D secondary west odd blanket $>1.8$ & -0.281213662 & 0.617880319 & -0.4551 & 0.6542 & -1.574452031 & 1.012024707 \\
\hline D sum of blanket $>3.8$ & 0.205032421 & 0.607350504 & 0.3376 & 0.7394 & -1.066166794 & 1.476231636 \\
\hline Sum of secondary blanket*Polymer at DAF & 0.000200375 & 0.000178721 & 1.1212 & 0.2762 & -0.000173692 & 0.000574442 \\
\hline Sum of secondary blanket * Sum RAS & $-5.94709 E-06$ & 7.05892E-06 & -0.8425 & 0.4100 & $-2.07216 \mathrm{E}-05$ & 8.82739E-06 \\
\hline D sum of FeCl3\&WPL $<21,000$ & 0.295546836 & 0.282308253 & 1.0469 & 0.3083 & -0.295331129 & 0.886424801 \\
\hline D polymer at dewatering $>2760$ & 0.941768727 & 0.470005332 & 2.0037 & 0.0596 & -0.041963739 & 1.925501193 \\
\hline Secondary west odd blanket & 0.116166325 & 0.192426969 & 0.6037 & 0.5532 & -0.28658795 & 0.5189206 \\
\hline
\end{tabular}


Model 4.

\begin{tabular}{|c|c|c|c|c|c|c|}
\hline Summary & $\begin{array}{l}\text { Multiple } \\
\quad \mathbf{R} \\
0.7176\end{array}$ & $\begin{array}{c}\text { R-Square } \\
0.5150\end{array}$ & $\begin{array}{c}\text { Adjusted } \\
\text { R-Square } \\
0.4201\end{array}$ & $\begin{array}{c}\text { StErr of } \\
\text { Estimate } \\
0.434001368\end{array}$ & & \\
\hline $\begin{array}{l}\text { ANOVA Table } \\
\text { Explained } \\
\text { Unexplained }\end{array}$ & $\begin{array}{c}\text { Degrees of } \\
\text { Freedom } \\
9 \\
46\end{array}$ & $\begin{array}{c}\text { Sum of } \\
\text { Squares } \\
9.200191516 \\
8.664430633\end{array}$ & $\begin{array}{c}\text { Mean of } \\
\text { Squares } \\
1.022243502 \\
0.188357188\end{array}$ & $\begin{array}{l}\text { F-Ratio } \\
5.4272\end{array}$ & $\begin{array}{c}\text { p-Value } \\
<0.0001\end{array}$ & \\
\hline & Coefficient & Standard & t-Value & p-Value & \multicolumn{2}{|c|}{ Confidence Interval 95\% } \\
\hline Regression Table & & Error & & & Lower & Upper \\
\hline Constant & 1.086883545 & 0.430872612 & 2.5225 & 0.0152 & 0.219581962 & 1.954185127 \\
\hline Polymer at Dewatering & -0.000125015 & 0.000136095 & -0.9186 & 0.3631 & -0.000398961 & 0.000148931 \\
\hline$\%$ of TWAS in Blend Tank & 0.835937762 & 0.732900665 & 1.1406 & 0.2599 & -0.639314759 & 2.311190283 \\
\hline D secondary west odd blanket $>1.8$ & 0.258751533 & 0.26953797 & 0.9600 & 0.3421 & -0.28380026 & 0.801303326 \\
\hline D sum of blanket $>3.8$ & 0.281509582 & 0.252981327 & 1.1128 & 0.2716 & -0.227715417 & 0.790734581 \\
\hline Sum of secondary blanket*Polymer at DAF & 2.29842E-05 & 1.64325E-05 & 1.3987 & 0.1686 & $-1.00928 E-05$ & 5.60611E-05 \\
\hline Sum of secondary blanket * Sum RAS & $-2.92184 \mathrm{E}-06$ & 3.44853E-06 & -0.8473 & 0.4012 & $-9.86337 \mathrm{E}-06$ & 4.01968E-06 \\
\hline D sum of FeCl3\&WPL $<21,000$ & -0.013568242 & 0.137123446 & -0.0989 & 0.9216 & -0.289583422 & 0.262446937 \\
\hline D polymer at dewatering $>2760$ & 1.163988299 & 0.314607674 & 3.6998 & 0.0006 & 0.530715898 & 1.7972607 \\
\hline Secondary west odd blanket & 0.028221749 & 0.113698546 & 0.2482 & 0.8051 & -0.200641553 & 0.257085052 \\
\hline
\end{tabular}


Model 5.

\begin{tabular}{|c|c|c|c|c|c|c|}
\hline Summary & $\begin{array}{l}\text { Multiple } \\
\quad \mathbf{R} \\
0.6902\end{array}$ & $\begin{array}{c}\text { R-Square } \\
0.4763\end{array}$ & $\begin{array}{c}\text { Adjusted } \\
\text { R-Square } \\
0.4240\end{array}$ & $\begin{array}{c}\text { StErr of } \\
\text { Estimate } \\
0.432552037\end{array}$ & & \\
\hline $\begin{array}{l}\text { ANOVA Table } \\
\text { Explained } \\
\text { Unexplained }\end{array}$ & $\begin{array}{c}\text { Degrees of } \\
\text { Freedom } \\
5 \\
50\end{array}$ & $\begin{array}{c}\text { Sum of } \\
\text { Squares } \\
8.509558897 \\
9.355063253\end{array}$ & $\begin{array}{c}\text { Mean of } \\
\text { Squares } \\
1.701911779 \\
0.187101265\end{array}$ & $\begin{array}{l}\text { F-Ratio } \\
9.0962\end{array}$ & $\begin{array}{c}\text { p-Value } \\
<0.0001\end{array}$ & \\
\hline & Coefficient & Standard & t-Value & p-Value & \multicolumn{2}{|c|}{ Confidence Interval 95\% } \\
\hline Regression Table & & Error & & & Lower & Upper \\
\hline Constant & 0.824031697 & 0.375113699 & 2.1968 & 0.0327 & 0.07059366 & 1.577469735 \\
\hline$\%$ of TWAS in Blend Tank & 0.699625666 & 0.706531104 & 0.9902 & 0.3268 & -0.719483819 & 2.118735151 \\
\hline D secondary west odd blanket $>1.8$ & 0.455324262 & 0.218783638 & 2.0812 & 0.0426 & 0.015884393 & 0.894764131 \\
\hline Sum of TPS \& TWAS * Polymer at dewatering & 2.30027E-11 & 4.39074E-11 & 0.5239 & 0.6027 & $-6.51879 E-11$ & 1.11193E-10 \\
\hline D polymer at dewatering $>2760$ & 1.160069842 & 0.23706601 & 4.8934 & $<0.0001$ & 0.683908748 & 1.636230936 \\
\hline Secondary west odd blanket & 0.052892613 & 0.065568453 & 0.8067 & 0.4237 & -0.0788055 & 0.184590726 \\
\hline
\end{tabular}


Model 6.

\begin{tabular}{|c|c|c|c|c|c|c|}
\hline Summary & $\begin{array}{c}\text { Multiple } \\
\quad \mathbf{R} \\
0.6826\end{array}$ & $\begin{array}{c}\text { R-Square } \\
0.4659\end{array}$ & $\begin{array}{c}\text { Adjusted } \\
\text { R-Square } \\
0.4125\end{array}$ & $\begin{array}{c}\text { StErr of } \\
\text { Estimate } \\
0.436833246\end{array}$ & & \\
\hline $\begin{array}{l}\text { ANOVA Table } \\
\text { Explained } \\
\text { Unexplained }\end{array}$ & $\begin{array}{c}\text { Degrees of } \\
\text { Freedom } \\
5 \\
50\end{array}$ & $\begin{array}{c}\text { Sum of } \\
\text { Squares } \\
8.323457922 \\
9.541164228\end{array}$ & $\begin{array}{c}\text { Mean of } \\
\text { Squares } \\
1.664691584 \\
0.190823285\end{array}$ & $\begin{array}{l}\text { F-Ratio } \\
8.7237\end{array}$ & $\begin{array}{c}\text { p-Value } \\
<0.0001\end{array}$ & \\
\hline & Coefficient & Standard & t-Value & p-Value & \multicolumn{2}{|c|}{ Confidence Interval 95\% } \\
\hline Regression Table & & Error & & & Lower & Upper \\
\hline Constant & 0.956877936 & 0.362068708 & 2.6428 & 0.0109 & 0.229641534 & 1.684114339 \\
\hline$\%$ of TWAS in Blend Tank & 0.667767981 & 0.715515029 & 0.9333 & 0.3552 & -0.769386248 & 2.104922211 \\
\hline D sum of blanket $>3.8$ & 0.380590758 & 0.210418831 & 1.8087 & 0.0765 & -0.042047902 & 0.803229418 \\
\hline Sum of TPS \& TWAS * Polymer at dewatering & $1.25898 \mathrm{E}-11$ & 4.48291E-11 & 0.2808 & 0.7800 & $-7.7452 E-11$ & $1.02632 \mathrm{E}-10$ \\
\hline D polymer at dewatering $>2760$ & 1.160590151 & 0.239682704 & 4.8422 & $<0.0001$ & 0.679173274 & 1.642007029 \\
\hline Secondary west odd blanket & 0.05142999 & 0.069815694 & 0.7367 & 0.4648 & -0.088798957 & 0.191658938 \\
\hline
\end{tabular}


Model 7.

\begin{tabular}{|c|c|c|c|c|c|c|}
\hline Summary & $\begin{array}{l}\text { Multiple } \\
\quad \mathbf{R} \\
0.6603\end{array}$ & $\begin{array}{c}\text { R-Square } \\
0.4359\end{array}$ & $\begin{array}{c}\text { Adjusted } \\
\text { R-Square } \\
0.3970\end{array}$ & $\begin{array}{c}\text { StErr of } \\
\text { Estimate } \\
0.463863467\end{array}$ & & \\
\hline $\begin{array}{l}\text { ANOVA Table } \\
\text { Explained } \\
\text { Unexplained }\end{array}$ & $\begin{array}{c}\text { Degrees of } \\
\text { Freedom } \\
4 \\
58\end{array}$ & $\begin{array}{c}\text { Sum of } \\
\text { Squares } \\
9.645036925 \\
12.47982034\end{array}$ & $\begin{array}{c}\text { Mean of } \\
\text { Squares } \\
2.411259231 \\
0.215169316\end{array}$ & $\begin{array}{l}\text { F-Ratio } \\
11.2063\end{array}$ & $\begin{array}{c}\text { p-Value } \\
<0.0001\end{array}$ & \\
\hline $\begin{array}{l}\text { Regression Table } \\
\text { Constant } \\
\% \text { of TWAS in Blend Tank } \\
\text { D secondary west odd blanket }>1.8 \\
\text { D polymer at dewatering }>2760 \\
\text { Secondary west odd blanket }\end{array}$ & $\begin{array}{c}\text { Coefficient } \\
0.763411977 \\
0.86015344 \\
0.431855318 \\
1.141857342 \\
0.08034464 \\
\end{array}$ & $\begin{array}{c}\begin{array}{c}\text { Standard } \\
\text { Error }\end{array} \\
0.363756897 \\
0.735934463 \\
0.210241068 \\
0.25306569 \\
0.067660636\end{array}$ & $\begin{array}{l}\text { t-Value } \\
2.0987 \\
1.1688 \\
2.0541 \\
4.5121 \\
1.1875 \\
\end{array}$ & $\begin{array}{c}\text { p-Value } \\
0.0402 \\
0.2473 \\
0.0445 \\
<0.0001 \\
0.2399\end{array}$ & $\begin{array}{c}\begin{array}{c}\text { Confiden } \\
\text { Lower }\end{array} \\
0.035273438 \\
-0.612979441 \\
0.011012095 \\
0.635291326 \\
-0.055092839\end{array}$ & $\begin{array}{c}\text { nterval } 95 \% \\
\text { Upper } \\
1.491550517 \\
2.33328632 \\
0.85269854 \\
1.648423357 \\
0.215782118\end{array}$ \\
\hline
\end{tabular}


Model 8.

\begin{tabular}{|c|c|c|c|c|c|c|}
\hline Summary & $\begin{array}{c}\text { Multiple } \\
\quad \mathbf{R} \\
0.6881\end{array}$ & $\begin{array}{l}\text { R-Square } \\
0.4734\end{array}$ & $\begin{array}{c}\text { Adjusted } \\
\text { R-Square } \\
0.4329\end{array}$ & $\begin{array}{c}\text { StErr of } \\
\text { Estimate } \\
0.428301653\end{array}$ & & \\
\hline $\begin{array}{l}\text { ANOVA Table } \\
\text { Explained } \\
\text { Unexplained }\end{array}$ & $\begin{array}{c}\text { Degrees of } \\
\text { Freedom } \\
4 \\
52\end{array}$ & $\begin{array}{c}\text { Sum of } \\
\text { Squares } \\
8.575769228 \\
9.53899991\end{array}$ & $\begin{array}{c}\text { Mean of } \\
\text { Squares } \\
2.143942307 \\
0.183442306\end{array}$ & $\begin{array}{l}\text { F-Ratio } \\
11.6873\end{array}$ & $\begin{array}{l}\text { p-Value } \\
<0.0001\end{array}$ & \\
\hline $\begin{array}{l}\text { Regression Table } \\
\text { Constant } \\
\text { D secondary west odd blanket }>1.8 \\
\text { Sum of TPS \& TWAS * Polymer at dewatering } \\
\text { D polymer at dewatering }>2760 \\
\text { Secondary west odd blanket }\end{array}$ & \begin{tabular}{c|} 
Coefficient \\
1.095105897 \\
0.400652654 \\
$3.18173 \mathrm{E}-11$ \\
1.226050376 \\
0.061494535
\end{tabular} & $\begin{array}{c}\text { Standard } \\
\text { Error } \\
0.20822154 \\
0.209335628 \\
2.2743 E-11 \\
0.224896202 \\
0.064351613\end{array}$ & $\begin{array}{l}\mathrm{t} \text {-Value } \\
5.2593 \\
1.9139 \\
1.3990 \\
5.4516 \\
0.9556\end{array}$ & $\begin{array}{c}\text { p-Value } \\
<0.0001 \\
0.0611 \\
0.1678 \\
<0.0001 \\
0.3437\end{array}$ & $\begin{array}{c}\begin{array}{c}\text { Confiden } \\
\text { Lower }\end{array} \\
0.67727881 \\
-0.019410014 \\
-1.38199 \mathrm{E}-11 \\
0.774763131 \\
-0.067636423\end{array}$ & $\begin{array}{c}\text { terval 95\% } \\
\text { Upper } \\
1.512932983 \\
0.820715322 \\
7.74546 \mathrm{E}-11 \\
1.67733762 \\
0.190625494\end{array}$ \\
\hline
\end{tabular}


Model 9.

\begin{tabular}{|c|c|c|c|c|c|c|}
\hline Summary & $\begin{array}{l}\text { Multiple } \\
\quad \mathbf{R} \\
0.6462\end{array}$ & $\begin{array}{l}\text { R-Square } \\
0.4175\end{array}$ & $\begin{array}{c}\text { Adjusted } \\
\text { R-Square } \\
0.3889\end{array}$ & $\begin{array}{c}\text { StErr of } \\
\text { Estimate } \\
0.466556471\end{array}$ & & \\
\hline $\begin{array}{l}\text { ANOVA Table } \\
\text { Explained } \\
\text { Unexplained }\end{array}$ & $\begin{array}{c}\text { Degrees of } \\
\text { Freedom } \\
3 \\
61\end{array}$ & $\begin{array}{c}\text { Sum of } \\
\text { Squares } \\
9.518000815 \\
13.27817139\end{array}$ & $\begin{array}{c}\text { Mean of } \\
\text { Squares } \\
3.172666938 \\
0.217674941\end{array}$ & $\begin{array}{l}\text { F-Ratio } \\
14.5753\end{array}$ & $\begin{array}{l}\text { p-Value } \\
<0.0001\end{array}$ & \\
\hline $\begin{array}{l}\text { Regression Table } \\
\text { Constant } \\
\text { D sum of blanket }>3.8 \\
\text { D polymer at dewatering }>2760 \\
\text { Secondary west odd blanket }\end{array}$ & $\begin{array}{c}\text { Coefficient } \\
1.182873177 \\
0.346714411 \\
1.096046402 \\
0.088337756\end{array}$ & $\begin{array}{c}\begin{array}{c}\text { Standard } \\
\text { Error }\end{array} \\
0.181211344 \\
0.195007788 \\
0.219634405 \\
0.071314821 \\
\end{array}$ & $\begin{array}{l}\text { t-Value } \\
6.5276 \\
1.7780 \\
4.9903 \\
1.2387 \\
\end{array}$ & $\begin{array}{c}\text { p-Value } \\
<0.0001 \\
0.0804 \\
<0.0001 \\
0.2202\end{array}$ & $\begin{array}{c}\text { Confidenc } \\
\text { Lower } \\
0.820518701 \\
-0.043227761 \\
0.656860266 \\
-0.054265042\end{array}$ & $\begin{array}{c}\text { terval 95\% } \\
\text { Upper } \\
1.545227654 \\
0.736656584 \\
1.535232538 \\
0.230940554\end{array}$ \\
\hline
\end{tabular}




\section{Reference}

Achen, C.H. 1982. Interpreting and using regression. Series: Quantitative Applications in the Social Sciences, No. 29. Thousand Oaks, CA

Bruce, A.M. 1984a. Assessment of Sludge Stability. In: Methods of

Characterization of Sewage Sludge. Ed. Bruce A.M., D. Reidel Publishing Company, London, UK. 131-143 pp.

Bruce, A.M. and W.J. Fisher. 1984b. Sludge Stabilization-Methods and Measurements. In: Sewage Sludge Stabilization and Disinfection. Ed. Bruce A.M., Ellis Horwood Ltd., Chichester, UK. 23-44 pp.

Churchill, RJ; Rybacki, RL. 1997. Polymer Addition Improves Waste Water Treatment Process. Water and Sewage Work, Reference Issue p 10-12, 14-17, 20

DCWASA. 2005. Blue Plains Advanced Wastewater Treatment Plant. District of Columbia Water and Sewer Authority Brochure.

DCWASA. 2006. Personal Communication with DCWASA Dept. of Wastewater Treatment.

Devore, L.J. 1987. Probability and statistics for engineering and the sciences.

Brooks/Cole Publishing Company, Monterey, CA.

Garson, D.G. 2006. PA: 765: Multiple Regression.

http://www2.chass.ncsu.edu/garson/PA765/regress.htm (accessed June 30, 2006)

Gabriel, S.A., Vilalai, S., Arispe, S. Kim, H., McConnell, L.L., Torrents, A., Peot, C., and Ramirez, M. 2005. Prediction of dimethyl disulfide levels from biosolids using statistical modeling. Journal of Environmental Science and Health, 40: 2009-2025

Gabriel, S.A., Vilalai, S., Peot, C., and Ramirez, M. 2006. Statistical modeling to forecasting odor levels of biosolids applied to reuse sites. Journal of Environmental Engineering, 132: 479-488

Gonano, L. 2002. Improving $\mathrm{H}_{2} \mathrm{~S}$ measurement results for odour monitoring instruments commonly used in the wastewater industry. Water industry workshop, Brisbane 2002

Jeris, J.S., D. Ciarcia, E. Chen and M. Mena. 1985. Determining the Stability of Treated Municipal Sludge. EPA 600/2-85-001, Off. Of Res. And Develop., EPA, Cincinnati, OH. 
Kim, H., Murthy, S.N., McConnell, L., Peot, C., Ramirez, M., Strawn, M. 2001a.

Examination of Mechanisms for Odor Compound Generation during Lime Stabilization, WEFTEC 2001.

Metcalf \& Eddy Inc., 1991. Wastewater Engineering: Collection, Treatment, and Disposal. McGraw-Hill, New York, NY.

Madigan, M.T., J.M. Martinko and J. Parker. 1997. Brock Biology of Microorganisms, $8^{\text {th }}$ edition. Prentice Hall, Upper Saddle River, NJ.

Metcalf \& Eddy Inc., 2003. Wastewater Engineering: Treatment, and Reuse. McGrawHill, New York, NY.

Murthy, S.N., Kim, H., Glindermann, D., Sadick, T., Peot, C., Bailey, W., McConnell, L., Novak, J. 2002a. Mechanisms for Odor Generation during Lime Stabilization. Water Research (Submitted).

North, J.M. 2003. An Evaluation of Methods for Quantifying Lime Incorporation into Mechanically Dewatered Sludge. MS thesis, Department of Civil and Environmental Engineering, Univ. of Maryland, College Park, MD.

Peot, Chris. Personal Communication .2006. DCWASA

Robens, J.F. 1980. Regulatory Aspects of Sludge Application to Land. In Sludge Health Risks of Land Application. G. Bitton, B.L. Damron, G.T. Edds and J.M. Davison. Ann Arbor Science. Ann Arbor, Michigan. 7-14 pp.

Sekyiamah, K.H. 2005. Identification of Seasonal Variations in Volatile Sulfur Compound Production and Release in the Secondary Treatment System of a Wastewater Treatment Plant. MS thesis, Department of Civil and Environmental Engineering, Univ. of Maryland, College Park, MD.

Switzenbaum, M.S., L.H. Moss, E. Epstein, A.B. Pincince and J.F. Donovan. 1997. Defining Biosolids Stability: A Basis for Public and Regulatory Acceptance. Water Environmental Research, Alexandria, VA.

Sudhir, Murthy. Personal Communication. 2006. DCWASA

Terry, A., Chloe, D,. Vladimir, K., Edward, T. 2001. Study of Hydrogen Sulfide Emissions from Wastewater Treatment Plants. Water Environment Federation

U.S. Environmental Protection Agency. 1979. Federal Register, 44, No. 179. 5342853464 pp. 
U.S. Environmental Protection Agency. 1994. A plain English Guide to the EPA Part 503 Biosolids Rule. EPA-832/R-93-003, Off of Wastewater Manage., U.S. EPA, Washington D.C.

U.S. Environmental Protection Agency. 1995. Process Design Manuel; Land Application of Sewage Sludge and Domestic Septage. EPA/626/K95/001, Off. of Res. and Develop., U.S. EPA, Cincinnati, OH.

U.S. Environmental Protection Agency. 2000. Biosolids Technology Fact Sheet Centrifuge Thickening and Dewatering. EPA 832-F-00-053, Off. Of Water., U.S. EPA, Washington D.C.

U.S. Environmental Protection Agency. 2000. Biosolids and Residuals Management Fact Sheet. EPA 832-F-00-067, Off. Of Water., U.S. EPA, Washington D.C.

Vesilind, P.A. 2003. Wastewater Treatment Plant Design. USA: Water Environment Federation.

Vilalai, S. 2003. Forecasting Odor Levels for Biosolids Product Based on Ambient Conditions. MS thesis, Department of Civil and Environmental Engineering, Univ. of Maryland, College Park, MD.

Water Environment Federation. 1995(a). Wastewater Residuals Stabilization, Manual of Practice FD-9. WEF, Alexandria, VA.

Water Environment Federation. 1995(b). Land Application of Sewage Sludge, Manual of Practice FD-9. WEF, Alexandria, VA.

Water Environment Federation. 1995(c). Odor Control in Wastewater Treatment Plants. WEF, Alexandria, VA, and ASCE, New York, NY.

Water Environment Federation. 1996. Operation of Municipal Wastewater Treatment Plants. WEF, Alexandria, VA.

Winston, L.W. 2004. Operation Research Applications and Algorithms. ThomsonBrooks/Cole, Belmont, CA. 